\title{
Impacts of Western Area Power Administration's Power Marketing Alternatives on Air Quality and Noise
}

by K.C. Chun, Y.-S. Chang, and J.A. Rabchuk

Environmental Assessment Division,

Argonne National Laboratory, 9700 South Cass Avenue, Argonne, llinois 60439

May 1995

Work sponsored by United States Department of Energy,

Western Area Power Administration 


\section{FOREWORD}

This report is one of a series of technical memorandums prepared to support an environmental impact statement (EIS) on power marketing prepared by Argonne National Laboratory for the U.S. Department of Energy's Western Area Power Administration (Western). Western markets electricity produced at hydroelectric facilities operated by the Bureau of Reclamation. The facilities are known collectively as the Salt Lake City Area Integrated Projects (SLCA/IP) and include dams equipped for power generation on the Colorado, Green, Gunnison, and Rio Grande rivers and on Plateau Creek in the states of Arizona, Colorado, New Mexico, Utah, and Wyoming.

Western proposes to establish a level of commitment (sales) of long-term firm electrical capacity and energy from the SLCA/IP hydroelectric power plants; the impacts of this proposed action are evaluated in the EIS. Of the SLCA/IP facilities, only the Glen Canyon Dam, Flaming Gorge Dam, and Aspinall Unit (which includes Blue Mesa, Morrow Point, and Crystal dams) are influenced by Western's power scheduling and transmission

decisions. For this reason, the impacts of hydropower operations at these three facilities were examined in the EIS.

The technical memorandums present detailed findings of studies conducted by Argonne National Laboratory specifically for the EIS. These studies are summarized in the EIS, and the results were used to assess environmental impacts related to alternative commitment levels. Technical memorandums were prepared on a number of socioeconomic and natural resource topics. Staff members of Argonne National Laboratory's Decision and Information Sciences Division and Environmental Assessment Division prepared these technical memorandums and the EIS as part of a joint effort managed by the Environmental Assessment Division. 


\section{CONTENTS}

FOREWORD $\ldots \ldots \ldots \ldots \ldots \ldots \ldots \ldots \ldots \ldots \ldots \ldots \ldots \ldots \ldots \ldots \ldots \ldots \ldots \ldots \ldots$ iii

NOTATION $\ldots \ldots \ldots \ldots \ldots \ldots \ldots \ldots \ldots \ldots \ldots \ldots \ldots \ldots \ldots \ldots \ldots$

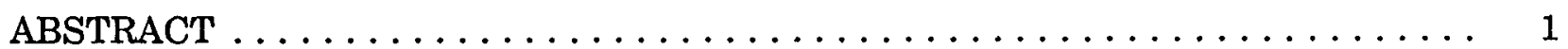

$1 \operatorname{INTRODUCTION} \ldots \ldots \ldots \ldots \ldots \ldots \ldots \ldots \ldots \ldots \ldots \ldots \ldots \ldots \ldots$

2 EXISTING ENVIRONMENT $\ldots \ldots \ldots \ldots \ldots \ldots \ldots \ldots \ldots \ldots$

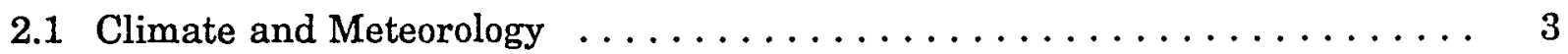

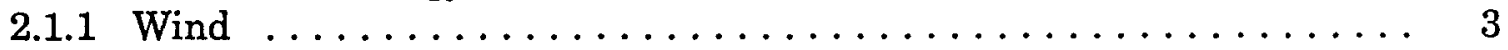

2.1.2 Temperature, Humidity, and Fog ................. 3

2.1.3 Precipitation and Evapotranspiration ................ 4

2.1.4 Severe Weather ........................ 4

2.1.5 Atmospheric Dispersion Characteristics ............... 4

2.2 Air Quality .............................. 5

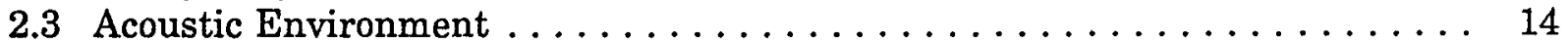

2.3.1 Noise Regulations and Guidelines . . . . . . . . . . . . 14

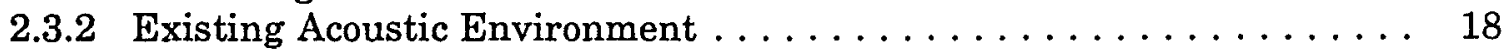

2.3.3 Estimated and Measured Noise Levels . . . . . . . . . . . . 21

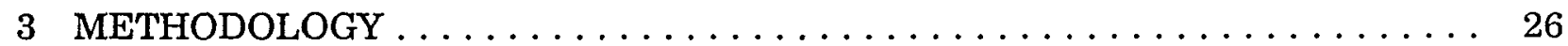

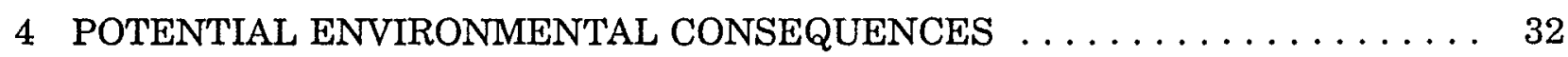

4.1 Air Quality .............................. 32

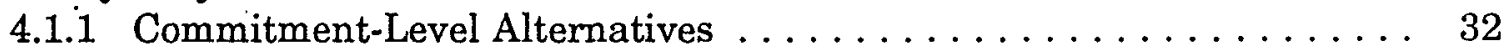

4.1 .2 Supply Options ... . . . . . . . . . . . . . . . . . . . 39

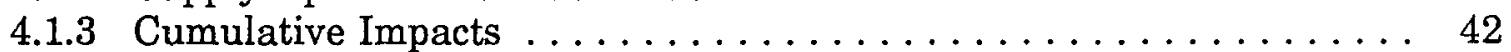

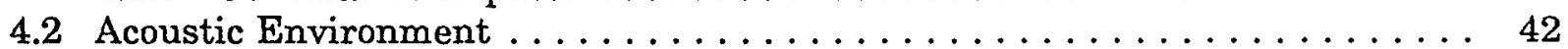

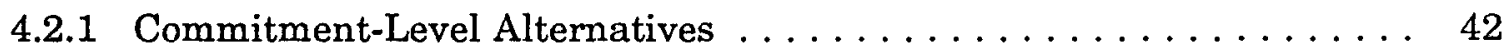

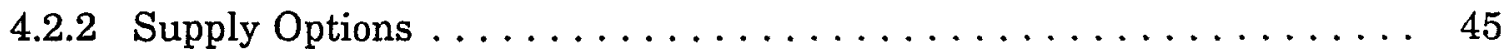

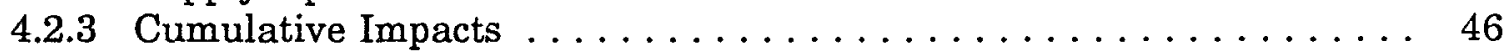

5 SUMMARY AND CONCLUSIONS $\ldots \ldots \ldots \ldots \ldots \ldots \ldots \ldots \ldots$

6 REFERENCES . . . . . . . . . . . . . . . . . . . . . . 49

APPENDLX: Air Quality . . . . . . . . . . . . . . . 53 


\section{FIGURES}

1 Areas within the Six-State Study Region Designated Nonattainment

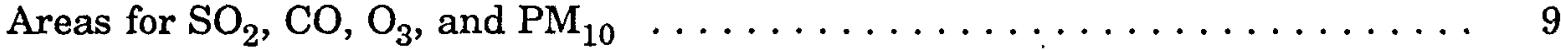

2 Major Electric Power Plants in the Six-State Study Region ........... 10

3 Contour Plot of Summer 1984 Median Standard Visual Range for the Contiguous United States $\ldots \ldots \ldots \ldots \ldots \ldots \ldots \ldots \ldots \ldots$

4 Federal Class I Air Quality Areas in the Contiguous United States . . . . . . 16

5 Components of Air Quality Impact Assessment $\ldots \ldots \ldots \ldots \ldots \ldots \ldots \ldots 27$

A.1 Ambient Air Quality Monitoring Stations for $\mathrm{SO}_{2}$ Operating in 1989 within the Six-State Study Region $\ldots \ldots \ldots \ldots \ldots \ldots \ldots \ldots . \ldots \ldots$

A.2 Ambient Air Quality Monitoring Stations for $\mathrm{NO}_{2}$ Operating in 1989 within the Six-State Study Region $\ldots \ldots \ldots \ldots \ldots \ldots \ldots \ldots$

A.3 Ambient Air Quality Monitoring Stations for CO Operating in 1989 within the Six-State Study Region $\ldots \ldots \ldots \ldots \ldots \ldots \ldots \ldots$

A.4 Ambient Air Quality Monitoring Stations for $\mathrm{O}_{3}$ Operating in 1989 within the Six-State Study Region $\ldots \ldots \ldots \ldots \ldots \ldots \ldots$

A.5 Ambient Air Quality Monitoring Stations for $\mathrm{PM}_{10}$ Operating in 1989 within the Six-State Study Region $\ldots \ldots \ldots \ldots \ldots \ldots \ldots \ldots$

A.6 Ambient Air Quality Monitoring Stations for TSP Operating in 1989 within the Six-State Study Region . . . . . . . . . . . . . . . .

A.7 Ambient Air Quality Monitoring Stations for Pb Operating in 1989 within the Six-State Study Region

\section{TABLES}

1 National Ambient Air Quality Standards and State Ambient Air Quality Standards for Criteria Pollutants Applicable to the

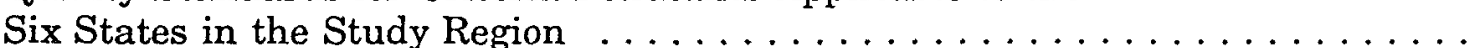

2 Designated Nonattainment Areas within the Colorado River Basin and the Six-State Study Region . . . . . . . . . . . . . . . . .

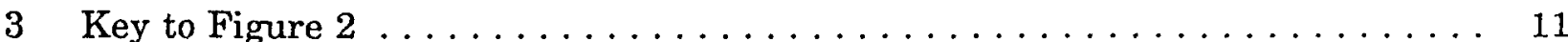




\section{TABLES (Cont.)}

4 Annual Emissions of $\mathrm{SO}_{2}, \mathrm{NO}_{x}$, and VOCs from Electric Utility and Other Sectors within the Six-State Study Region, 1981-1990 . . . . . . .

5 Annual Emissions of $\mathrm{CO}_{2}$ from Electric Utility and Other Sectors within the Six-State Study Region and the United States, 1981-1990 _ . . . . 13

6 State of Colorado Regulations on Maximum Permissible Noise Levels . . . . . . .

7 Predicted and Measured Residual Noise Levels and Spectra at Sensitive Receptors in the Vicinity of the Glen Canyon and Flaming Gorge Plants and the Curecanti Substation Transformer ...................

8 Predicted Noise Levels at the Sensitive Receptors Contributed by Step-up and Substation Transformers at the Glen Canyon and Flaming Gorge Plants and the Curecanti Substation Transformer $\ldots \ldots \ldots \ldots \ldots \ldots \ldots$

9 Characteristics of Transformers at the Glen Canyon, Flaming Gorge,

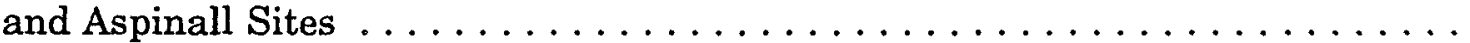

10 Elevations and Types of Ground Cover for the Areas from the Hydroelectric Plants and/or Their Substations to the Selected Receptor Locations . . . . . . . . . . . . . . . . . . . . . .

11 New Generation Capacities of the Region's 17 Utility Systems

Projected for 1998 and 2008 under Selected Commitment-Level

Alternatives and Operational Scenarios . . . . . . . . . . . . . . .

12 Air Pollutant Emission Factors Weighted for Projected Electric

Energy Generation by the Region's 17 Electric Utility Systems

13 Air Pollutant Emission Factors Assigned to Projected New

Generating Units . . . . . . . . . . . . . . . . . . . . . .

14 Changes in Annual Generation and Capacity Factor of Existing Peaking Units under Selected Commitment-Level Alternatives in 1993,1998 , and $2008 \ldots \ldots \ldots \ldots \ldots \ldots \ldots \ldots \ldots$

15 Changes in Annual Generation and Capacity Factor of Existing Intermediate and Baseload Units under Selected Commitment-Level Alternatives in 1993,1998 , and $2008 \ldots \ldots \ldots \ldots \ldots \ldots \ldots$

16 Changes in Annual Generation and Capacity Factor of New Peaking Units under Selected Commitment-Level Alternatives in 1998 and 2008

17 Changes in Annual Generation and Capacity Factor of New Intermediate and Baseload Units under Selected Commitment-Level Alternatives in 1998 and 2008 


\section{TABLES (Cont.)}

18 Annual Emissions of $\mathrm{SO}_{2}, \mathrm{NO}_{\mathrm{x}}, \mathrm{TSP}$, and $\mathrm{CO}_{2}$ from Electric Energy Generated by 17 Utility Systems under Selected Commitment-Level Alternatives for 1993,1998 , and 2008

19 Annual Emissions of $\mathrm{SO}_{2}, \mathrm{NO}_{\mathrm{x}}$, TSP, and $\mathrm{CO}_{2}$ from Electric Energy Generated by 17 Utility Systems under Selected Operational Scenarios for 1993, 1998, and 2008

A.1 Estimated Air Quality Impacts of Electric Power Generation from Diesel Engine Operations

A.2 Estimated Air Quality Impacts of Electric Power Generation from Natural-Gas-Fired Gas Turbine Operations . . . . . . . . . . . . . 64

A.3 Estimated Air Quality Impacts of Electric Power Generation from Natural-Gas-Fired Combined-Cycle Plant Operations

A.4 Estimated Air Quality Impacts of Electric Power Generation from Pulverized-Coal-Fired Plant Operations . . . . . . . . . . . . . 


\section{NOTATION}

The following is a list of the acronyms, initialisms, and abbreviations (including units of measure) used in this document. Some acronyms used in tables only are defined in the respective tables.

\section{ACRONYMS, INITLALISMS, AND ABBREVIATIONS}

$\begin{array}{ll}\mathrm{CFR} & \text { Code of Federal Regulations } \\ \mathrm{CH}_{4} & \begin{array}{l}\text { methane } \\ \text { carbon monoxide }\end{array} \\ \mathrm{CO} & \text { carbon dioxide } \\ \mathrm{CO}_{2} & \text { Environmental Noise Model } \\ \mathrm{ENM} & \text { U.S. Environmental Protection Agency } \\ \mathrm{EPA} & \text { Industrial Source Complex (model) } \\ \mathrm{ISC} & \text { day-night weighted equivalent sound level } \\ \mathrm{L}_{\mathrm{dn}} & \text { equivalent steady sound level that, if continuous during a specific time period, } \\ \mathrm{L}_{\mathrm{eq}} & \text { would contain the same total energy as the actual time-varying sound } \\ \mathrm{NAAQS} & \text { National Ambient Air Quality Standards } \\ \mathrm{N}_{2} \mathrm{O} & \text { nitrous oxide } \\ \mathrm{NO}_{2} & \text { nitrogen dioxide } \\ \mathrm{NO}_{\mathrm{x}} & \text { nitrogen oxides } \\ \mathrm{O}_{3} & \text { ozone } \\ \mathrm{PACE} & \text { Production and Capacity Expansion (model) } \\ \mathrm{Pb} & \text { lead } \\ \mathrm{PM} & \text { particulate matter with an aerodynamic diameter of } \leq 10 \mu \mathrm{m} \\ \mathrm{SAAQS} & \text { State Ambient Air Quality Standards } \\ \mathrm{SMNM} & \text { Spot Market Network Model } \\ \mathrm{SO} & \text { sulfur dioxide } \\ \mathrm{TSP} & \text { total suspended particulates } \\ \text { VOC } & \text { volatile organic compound }\end{array}$

\section{UNITS OF MEASURE}

$\begin{array}{llll}{ }^{\circ} \mathrm{C} & \text { degree(s) Celsius } & \mu \mathrm{g} & \text { microgram(s) } \\ { }^{\circ} \mathrm{F} & \text { degree(s) fahrenheit } & \mu \mathrm{m} & \text { micrometer(s) } \\ \mathrm{Btu} & \text { British thermal unit(s) } & \mathrm{m} & \text { meter(s) } \\ \mathrm{dB} & \text { decibel(s) } & \mathrm{m}^{3} & \text { cubic meter(s) } \\ \mathrm{dBA} & \text { decibel(s), A-weighted } & \mathrm{mi} & \text { mile(s) } \\ \mathrm{ft} & \text { foot (feet) } & \mathrm{mph} & \text { mile(s) per hour } \\ \mathrm{GWh} & \text { gigawatt-hour(s) } & \mathrm{MVA} & \text { megavolt ampere(s) } \\ \mathrm{h} & \text { hour(s) } & \mathrm{MW} & \text { megawatt(s) } \\ \mathrm{Hz} & \text { hertz } & \mathrm{s} & \text { second(s) } \\ \mathrm{in} . & \text { inch(es) } & \mathrm{yr} & \text { year(s) } \\ \mathrm{lb} & \text { pound(s) } & & \end{array}$




\title{
IMPACTS OF WESTERN AREA POWER ADMINISTRATION'S POWER MARKETING ALTERNATIVES ON AIR QUALITY AND NOISE
}

by

\author{
K.C. Chun, Y.-S. Chang, and J.A. Rabchuk
}

\begin{abstract}
The Western Area Power Administration, which is responsible for marketing electricity produced at the hydroelectric power-generating facilities operated by the Bureau of Reclamation on the Upper Colorado River, has proposed changes in the levels of its commitment (sales) of longterm firm capacity and energy to its customers. This report describes (1) the existing conditions of air resources (climate and meteorology, ambient air quality, and acoustic environment) of the region potentially affected by the proposed action and (2) the methodology used and the results of analyses conducted to assess the potential impacts on air resources of the proposed action and the commitment-level alternatives. Analyses were performed for the potential impacts of both commitment-level alternatives and supply options, which include combinations of electric power purchases and different operational scenarios of the hydroelectric power-generating facilities.
\end{abstract}

\section{INTRODUCTION}

The Western Area Power Administration (Western) is responsible for marketing electricity produced at the hydroelectric power-generating facilities operated by the Bureau of Reclamation on the Upper Colorado River. Western is considering changes in the levels of its commitment (sales) of long-term firm capacity and energy to its customers. Different capacity and energy-level commitments by Western under various commitment-level alternatives would affect the levels and mix of electric energy produced with different fuels by generating units owned by the region's utility systems, causing changes in the associated air pollutant and noise emissions and consequent impacts on air resources (climate and meteorology, air quality, and acoustic environment). Operations at the hydroelectric plants under each of the commitment-level alternatives could also cause impacts on the environment, including air resources. An operational change from highly fluctuating releases to less fluctuating releases means that power production at Western's hydroelectric generating units would be made more uniform throughout the day. Compared with the high fluctuating flows typical of historical operations, hydroelectric power production would be lower during the peak demand period and increased during the off-peak demand period. The hydroelectric 
energy that was no longer available during the peak demand period would have to be supplied by other peaking units. During the off-peak period, however, electrical generation from baseload units would be reduced to make use of the additional hydroelectric energy. Thus, with reduced fluctuations, a certain amount of the region's baseload electric energy (with generally higher emission factors) would be replaced by the electric energy generated by the region's nonhydroelectric peaking units (with generally lower emission factors). As a result, a net decrease in air pollutant emissions could occur. Thus, the air pollutant emissions by the region's utility systems would be expected to decrease in general as hydroelectric operations changed from high fluctuating flows to steady flows.

Environmental impacts on air resources have been assessed for the period 1993-2008 in a six-state study region. Potential impacts are estimated for the projected new generating capacity additions needed to replace retired units and to meet the region's growing power demand. New generating units projected include diesel engines, gas turbines, combined cycle units, and pulverized coal power plants of various sizes. Construction and operation of these new generating units would result in (1) emissions of air pollutants, including those from fossil-fuel combustion, and (2) noise emissions from equipment. Detailed assessments of potential air quality and noise impacts would be needed if individual facilities were proposed at specific sites, but such detailed, site-specific assessments are beyond the scope of this study.

Section 2 of this report presents a brief description of the study region's air resources. The methodologies used for the analyses and the analytical results are described in Sections 3 and 4, respectively. Conclusions derived from the analytical results are discussed in Section 5. Further details on existing conditions and environmental consequences for air quality are provided in the appendix. 


\section{EXISTING ENVIRONMENT}

\subsection{CLIMATE AND METEOROLOGY}

The six-state study region assessed for this analysis includes Arizona, Colorado, Nevada, New Mexico, Utah, and Wyoming. The climate of this region is generally semiarid to arid. It is characterized by low precipitation, low humidity, highly variable (but generally warm) temperatures, and light winds. All of these parameters vary greatly with topography and latitude. Summer storms with heavy downpours and strong winds contribute most of the total annual precipitation in the northern part of the region, whereas winter storms are important contributors in the southern part of the region. Average temperatures range from freezing in the high mountains to $50^{\circ} \mathrm{F}$ in the lower mountains and plateaus and up to $70^{\circ} \mathrm{F}$ in the desert region to the south. Winds in the region generally move from west to east. The characteristics of climate and meteorology described for the six-state study region in Sections 2.1.1 through 2.1.5 are based on Ruffner (1985), National Oceanic and Atmospheric Administration (1990a-g), U.S. Army Corps of Engineers (1982), and Upper Colorado Region State-Federal Inter-Agency Group (1971).

\subsubsection{Wind}

Winds in the region move generally from west to east but are greatly modified by local topographic features. Mountain slopes with westerly exposure experience high wind velocities, whereas wind speeds are relatively low in the protected valleys. During much of the year, high-pressure regions dominate, causing only light wind movement. Surface winds are most often associated with the movement of air masses upslope during the day and downslope during the night. In the desert and plateau regions, the strongest winds are associated with summer rainstorms and can reach speeds of up to $100 \mathrm{mph}$. In the northernmost regions and in the mountains, the highest wind speeds are recorded during winter and spring.

\subsubsection{Temperature, Humidity, and Fog}

Temperatures in the region differ widely with elevation, latitude, season, and time of day. Temperatures vary about $3^{\circ} \mathrm{F}$ per $1,000 \mathrm{ft}$ of elevation. Average temperatures range from freezing in the high mountains to $50^{\circ} \mathrm{F}$ in the lower mountains and plateaus, and to $70^{\circ} \mathrm{F}$ in the desert regions to the south. In New Mexico, average temperatures between points of similar elevation vary about $0.6^{\circ} \mathrm{F}$ per $1^{\circ}$ latitude; in Utah, the variation is about 1.5 to $2^{\circ} \mathrm{F}$ per $1^{\circ}$ latitude. The mean monthly temperature is highest in July and lowest in January. Diurnal variations are usually large in summer, averaging about $40^{\circ} \mathrm{F}$ and as much as 50 to $60^{\circ} \mathrm{F}$ in desert regions. During winter, these variations average about 20 to $25^{\circ} \mathrm{F}$, although they can be higher in the desert regions. 
Humidity is generally quite low, especially in the deserts in the southern portion of the region. Annual average relative humidity values, based on four readings per day, range from $30 \%$ in Las Vegas, Nevada, and $36 \%$ in Phoenix, Arizona, to 55\% in Salt Lake City, Utah, and 56\% in Casper, Wyoming. Because of the low humidity, days with heavy fog are rare, especially in the desert regions in the lower basin. The annual average number of days with heavy fog limiting visibility to $0.25 \mathrm{mi}$ or less ranges from 0.7 in Las Vegas, Nevada, and 1.5 in Phoenix, Arizona, to 11.4 in Flagstaff, Arizona, and 11.5 in Salt Lake City, Utah.

\subsubsection{Precipitation and Evapotranspiration}

An average of 14 in./yr of precipitation falls on the Colorado River Basin. The local annual precipitation varies from less than 5 in. in desert regions to more than 50 in. at the highest mountain elevations. For most of the upper basin, the largest part of the annual precipitation occurs during October through April from Pacific storms. In the lower basin, summer storms from the Gulfs of California and Mexico during July through September account for the largest part of annual precipitation; however, precipitation is highly variable from year to year and can be less in summer than in winter.

High evaporation rates throughout the river basin result from a combination of high temperatures, low humidities, clear skies, and moderate winds. In northern Arizona, annual evaporation rates range from about $30 \mathrm{in}$. at high elevations to about $60 \mathrm{in}$. in the lower valleys. In central and southern Arizona, annual evaporation rates range from about 50 in. to more than 80 in. along the Colorado river.

\subsubsection{Severe Weather}

Thunderstorms in the basin usually result from air masses moving into the region from the Gulfs of California and Mexico, and they occur most frequently in the lower basin during July through September. The thunderstorms consist of heavy downpours, which are often associated with high winds that occasionally reach speeds of up to $100 \mathrm{mph}$. The annual average number of thunderstorms ranges from 7 in Yuma, Arizona, and 14 in Las Vegas, Nevada, to 42 and 51 in Tucson and Flagstaff, Arizona, respectively. Tornadoes are less frequent and destructive in this region than in the Midwest. Severe weather in the upper basin is most often associated with winter storms, which are widespread and usually last several days.

\subsubsection{Atmospheric Dispersion Characteristics}

Atmospheric dispersion of air pollutants increases if the wind speed increases, the atmospheric stability lessens, and the depth of the mixing layer (mixing height) increases. Annual and seasonal data for average wind speed throughout the mixing layer, mixing 
height, and normalized average pollutant concentration values ${ }^{1}$ for the contiguous United States have been estimated and presented as isopleth maps by Holzworth (1972). These isopleth maps indicate that the conditions for atmospheric dispersion in this region are, compared with other regions of the United States, generally poorer during morning hours but somewhat better during afternoon hours. The worst conditions for atmospheric dispersion exist during the winter months, when the average mixing height is lowest in both morning and afternoon and the average wind speed in the mixing layer is reduced.

\subsection{AIR QUALITY}

The six-state study region encompasses many major population centers, including Phoenix and Tucson, Arizona; Denver and Colorado Springs, Colorado; Albuquerque, New Mexico; Las Vegas, Nevada; and Salt Lake City, Utah. These cities and some of their suburbs are designated as nonattainment areas with respect to one or more of the National Ambient Air Quality Standards (NAAQS) (Title 40, Code of Federal Regulations, Part 50 [40 CFR 50]). All remaining areas of the region are designated as either in attainment or unclassified with respect to all criteria pollutants. The NAAQS and the State Ambient Air Quality Standards (SAAQS) for each of the six states in the study region are listed in Table 1; nonattainment areas within the six-state study region are listed in Table 2, and their locations are shown in Figure 1.

Nonattainment areas that are not associated with large population centers include (1) those for total suspended particulates (TSP) (Trona Industrial Park in Wyoming and the Grand Junction area in Colorado), where high levels of dust are emitted from sources such as unpaved roads and road sanding in winter, and (2) those for sulfur dioxide $\left(\mathrm{SO}_{2}\right)$ and/or TSP, which involve a number of small cities in Arizona with large power-generation facilities or mining operations. These cities are all located in the southernmost part of the state, except for Joseph City in the northeastern quadrant of the state.

The electric utility sector is a major contributor to the overall air pollutant emissions related to human activities within the six-state study region. The location, name, generating capacity, and type of major electric generating plants within the study region are shown in Figure 2 and Table 3. Annual emissions from the region's electric utilities of $\mathrm{SO}_{2}$ and nitrogen oxides $\left(\mathrm{NO}_{\mathrm{x}}\right)$, the precursor pollutants for acid deposition and visibility impairment, represented approximately 49 and 56\%, respectively, of the region's total human-related emissions of these pollutants in 1990. However, the electric utility sector contributes only small amounts of TSP and volatile organic compounds (VOCs) (Table 4). Annual emissions of carbon dioxide $\left(\mathrm{CO}_{2}\right)$, a greenhouse gas, from the electric utility sector in the region

1 A theoretical, city-wide average pollutant concentration over urban areas was developed on the basis of a simple dispersion model, normalized for a uniform average area emission rate (Holzworth 1972). 
TABLE 1 National Ambient Air Quality Standards (NAAQS) and State Ambient Air Quality Standards (SAAQS) for Criteria Pollutants Applicable to the Six States in the Study Region

\begin{tabular}{|c|c|c|c|c|c|c|c|c|c|}
\hline \multirow[b]{2}{*}{ Pollutant ${ }^{a}$} & \multirow{2}{*}{$\begin{array}{c}\text { Averaging } \\
\text { Time }\end{array}$} & \multicolumn{2}{|c|}{$\operatorname{NAAQS}^{b, c}\left(\mu \mathrm{g} / \mathrm{m}^{3}\right)$} & \multicolumn{6}{|c|}{$\operatorname{SAAQS}^{c}\left(\mu \mathrm{g} / \mathrm{m}^{3}\right)$} \\
\hline & & Primary & Secondary & Arizona $^{d}$ & Colorado $^{e}$ & Nevada ${ }^{\theta}$ & New Mexicof & Utah $^{e}$ & Wyoming $^{\theta}$ \\
\hline \multirow{3}{*}{$\mathrm{SO}_{2}$} & Annual & 80 & - & 80 & 80 & 80 & 60 & 80 & 60 \\
\hline & 24 hours & 365 & - & 365 & 365 & 365 & 260 & 365 & 260 \\
\hline & 3 hours & - & 1,300 & 1,300 & 1,300 & 1,300 & 1,300 & 1,300 & 1,300 \\
\hline \multirow{2}{*}{$\mathrm{NO}_{2}$} & Annual & 100 & 100 & 100 & 100 & 100 & 100 & 100 & 100 \\
\hline & 24 hours & - & - & - & - & - & 200 & - & - \\
\hline \multirow[t]{2}{*}{$\mathrm{CO}$} & 8 hours & 10,000 & 10,000 & 10,000 & 10,000 & 10,000 & 9,200 & 10,000 & 10,000 \\
\hline & 1 hour & 40,000 & 40,000 & 40,000 & 40,000 & 40,000 & 14,800 & 40,000 & 40,000 \\
\hline $\mathrm{O}_{3}$ & 1 hour & 235 & 235 & 235 & 235 & 235 & 118 & 235 & 160 \\
\hline \multirow[t]{2}{*}{ TSPg } & Annual $^{h}$ & - & - & - & 75 & 75 & 60 & - & - \\
\hline & 24 hours & - & - & - & 260 & 150 & 150 & - & 150 \\
\hline \multirow{2}{*}{$\mathrm{PM}_{10}$} & Annual $^{\mathrm{i}}$ & 50 & 50 & 50 & 50 & 50 & 50 & 50 & 50 \\
\hline & 24 hours & 150 & 150 & 150 & 150 & 150 & 150 & 150 & 150 \\
\hline \multirow[t]{2}{*}{$\mathrm{Pb}$} & Calendar & & & & & & & & \\
\hline & quarter & 1.5 & 1.5 & 1.5 & 1.5 & 1.5 & 1.5 & 1.5 & 1.5 \\
\hline
\end{tabular}

See footnotes on next page. 


\section{TABLE 1 (Cont.)}

a Notation: $\mathrm{CO}=$ carbon monoxide; $\mathrm{NO}_{2}=$ nitrogen dioxide; $\mathrm{O}_{3}=$ ozone; $\mathrm{Pb}=$ lead particulate matter; $\mathrm{PM}_{10}=$ particulate matter $\leq 10 \mu \mathrm{m}$, $\mathrm{SO}_{2}=$ sulfur dioxide; and $\mathrm{TSP}=$ total suspended particulates.

b National Ambient Air Quality Standards (NAAQS), other than those for $\mathrm{O}_{3}$ and $\mathrm{PM}_{10}$ and those based on annual averages, are not to be exceeded more than once per year. The $\mathrm{O}_{3}$ standard is attained when the expected number of days per calendar year with maximum hourly average concentrations above the standard is less than or equal to one. The 24-hour $\mathrm{PM}_{10}$ standard is attained when the expected number of days with a 24-hour average concentration above the standard is less than or equal to one. The annual arithmetic mean $\mathrm{PM}_{10}$ standard is attained when the expected annual arithmetic mean concentration is less than or equal to the standard.

c A hyphen indicates that no standard exists.

d State annual standards are never to be exceeded; short-term standards are not to be exceeded more than once per year, with two exceptions.

e The procedures for determining attainment of the state standards are the same as for the NAAQS.

f All state standards are not to be exceeded.

$\mathrm{g}$ The TSP standards have been replaced by the $\mathrm{PM}_{10}$ standards, but the former are serving as interim standards for certain states.

h Geometric mean of all values reported during the year.

$i$ Arithmetic mean of the quarterly arithmetic means for the four calendar quarters of the year.

Sources: Code of Federal Regulations, Title 40, Part 50; Arizona Administrative Rules and Regulations, Title 18, Chapter 2, Article 2; Code of Colorado Regulations, Volume 5, Part 14; Nevada Administrative Code, Chapter 445; New Mexico Environmental Improvement Board Ambient Air Quality Standards and Air Quality Control Regulations, Sections 100-1301; Utah Air Conservation Regulations, Utah Department of Health R4446; and Wyoming Rules and Regulations of Department of Environmental Quality, Air Quality Division, Chapter 1. 
TABLE 2 Designated Nonattainment Areas within the Colorado River Basin and the Six-State Study Region

\begin{tabular}{|c|c|c|c|c|c|}
\hline \multicolumn{6}{|c|}{ Nonattainment Areas for Respective Pollutants ${ }^{\mathbf{a}}$} \\
\hline State & $\mathrm{SO}_{2}$ & $\mathrm{CO}$ & $\mathrm{O}_{3}$ & $\mathrm{TSP}^{\mathrm{b}}$ & $\mathrm{PM}_{10}$ \\
\hline Arizona & $\begin{array}{l}\text { Portions of Ajo, Douglas, } \\
\text { Hayden, Miami, Morenci, } \\
\text { and San Manuel }\end{array}$ & $\begin{array}{l}\text { Portions of Maricopa } \\
\text { County }{ }^{c} \text { (Phoenix area) } \\
\text { and Pima County } \\
\text { (Tucson area) }\end{array}$ & $\begin{array}{l}\text { Portion of Maricopa } \\
\text { County }{ }^{c} \text { (Phoenix area) }\end{array}$ & $\begin{array}{l}\text { Portions of Ajo, Douglas, } \\
\text { Hayden, Joseph City, Miami, } \\
\text { Morenci, Paul Spur, } \\
\text { Phoenix, and Tucson }\end{array}$ & $\begin{array}{l}\text { Portions of Cochise, Gila, } \\
\text { Maricopa, Pinal, Santa } \\
\text { Cruz, and Yuma counties }^{c}\end{array}$ \\
\hline Colorado & None & $\begin{array}{l}\text { Colorado Springs area, } \\
\text { Denver-Boulder area, } \\
\text { Fort Collins area, } \\
{ }^{c} \\
\text { Greeley area, and } \\
\text { Longmont area }{ }^{c}\end{array}$ & $\begin{array}{l}\text { Denver, Douglas, and } \\
\text { Jefferson counties; } \\
\text { portions of Adams, } \\
\text { Arapahoe, and Boulder } \\
\text { counties }^{\text {e }}\end{array}$ & $\begin{array}{l}\text { Fort Collins, Greeley, } \\
\text { Denver UA, Boulder UA, } \\
\text { Colorado Springs 3-C UA, } \\
\text { and Grand Junction UA }\end{array}$ & $\begin{array}{l}\text { Denver metropolitan area, } \\
\text { Aspen, Canon City, Lamar, } \\
\text { Pagosa Springs, and } \\
\text { Telluride }^{c}\end{array}$ \\
\hline Nevada & Steptoe Valley & $\begin{array}{l}\text { Lake Tahoe (Nevada) } \\
\text { area, }{ }^{\text {d Las Vegas area, }}{ }^{c} \\
\text { and Reno areac }\end{array}$ & $\begin{array}{l}\text { Reno area }{ }^{f} \text { (Washoe } \\
\text { County) }\end{array}$ & $\begin{array}{l}\text { Las Vegas Valley, Carson } \\
\text { Desert, Winnemucca } \\
\text { segment, Lower Reese } \\
\text { Valley, Fernley area, } \\
\text { Truckee Meadows, Mason } \\
\text { Valley, and Clovers area }\end{array}$ & $\begin{array}{l}\text { Portions of Washoe and } \\
\text { Clark counties }\end{array}$ \\
\hline New Mexico & Portions of Grant County & Bernalillo County ${ }^{c}$ & None & $\begin{array}{l}\text { Portions of city of } \\
\text { Albuquerque }\end{array}$ & $\begin{array}{l}\text { Portion of Dona Ana } \\
\text { County }^{c}\end{array}$ \\
\hline Utah & $\begin{array}{l}\text { Salt Lake County } \\
\text { and portions of } \\
\text { Tooele County }\end{array}$ & $\begin{array}{l}\text { Salt Lake City, }{ }^{d} \text { Ogden, } \\
\text { and Provo }{ }^{c}\end{array}$ & $\begin{array}{l}\text { Salt Lake and Davis } \\
\text { counties }^{c}\end{array}$ & $\begin{array}{l}\text { Portions of Salt Lake and } \\
\text { Utah counties }\end{array}$ & $\begin{array}{l}\text { Salt Lake and Utah } \\
\text { counties }^{c}\end{array}$ \\
\hline Wyoming & None & None & None & $\begin{array}{l}\text { Trona industrial area in } \\
\text { Sweetwater County }\end{array}$ & City of Sheridan ${ }^{c}$ \\
\hline
\end{tabular}

a For $\mathrm{PM}_{10}$, initial nonattainment area.

b Notation: UA indicates urban area or urbanized area; 3-C UA is a planning term used to designate continuing, cooperative, and comprehensive transportation planning area boundaries.

c Moderate nonattainment.

d Not classified.

e Transitional nonattainment.

f Marginal.

Source: Code of Federal Regulations, Title 40, Part 81, Subpart C. 

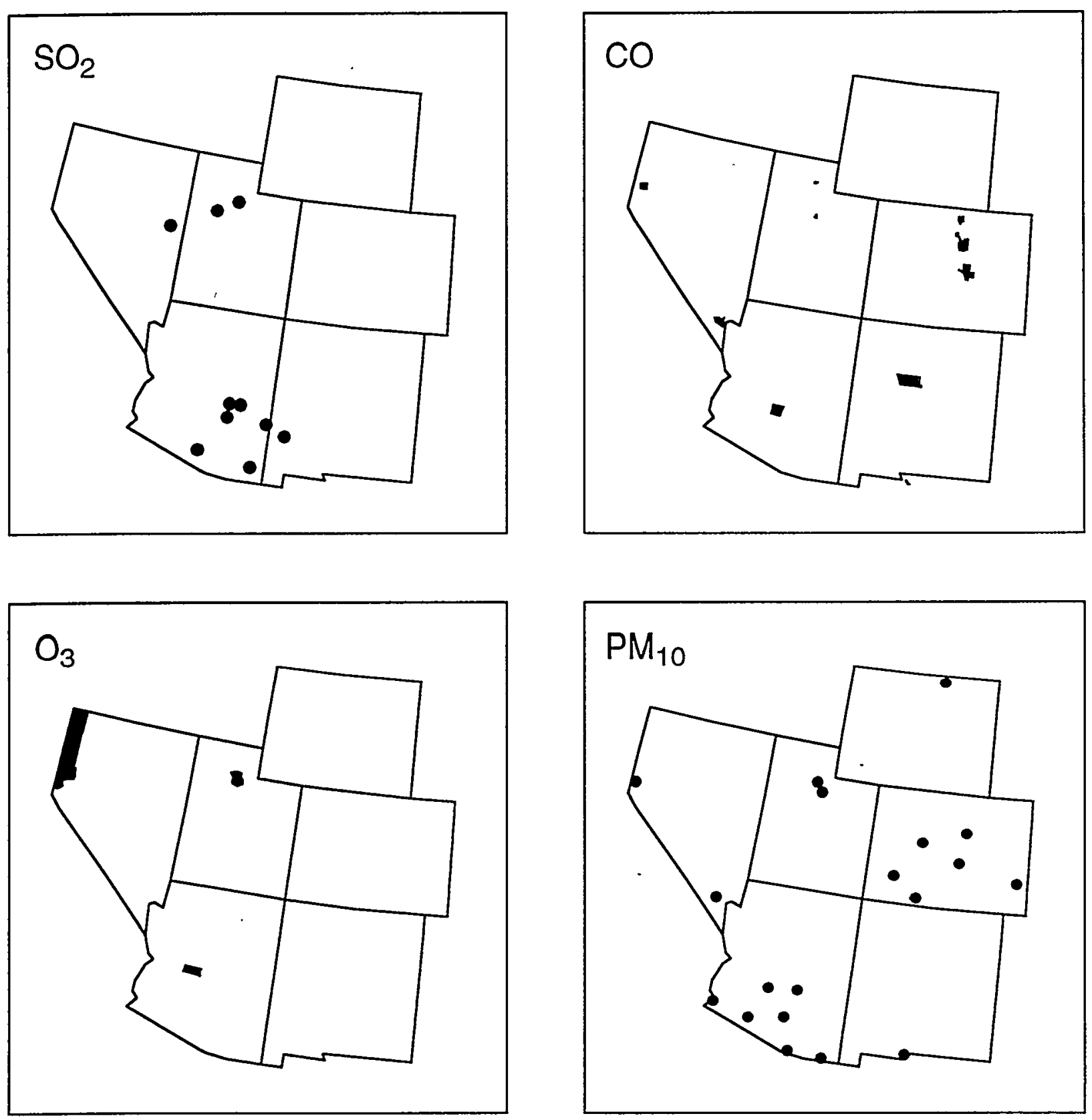

FIGURE 1 Areas within the Six-State Study Region Designated Nonattainment Areas for $\mathrm{SO}_{2}, \mathrm{CO}, \mathrm{O}_{3}$, and $\mathrm{PM}_{10}$ (Adapted from U.S. Environmental Protection Agency [EPA] 1991) 


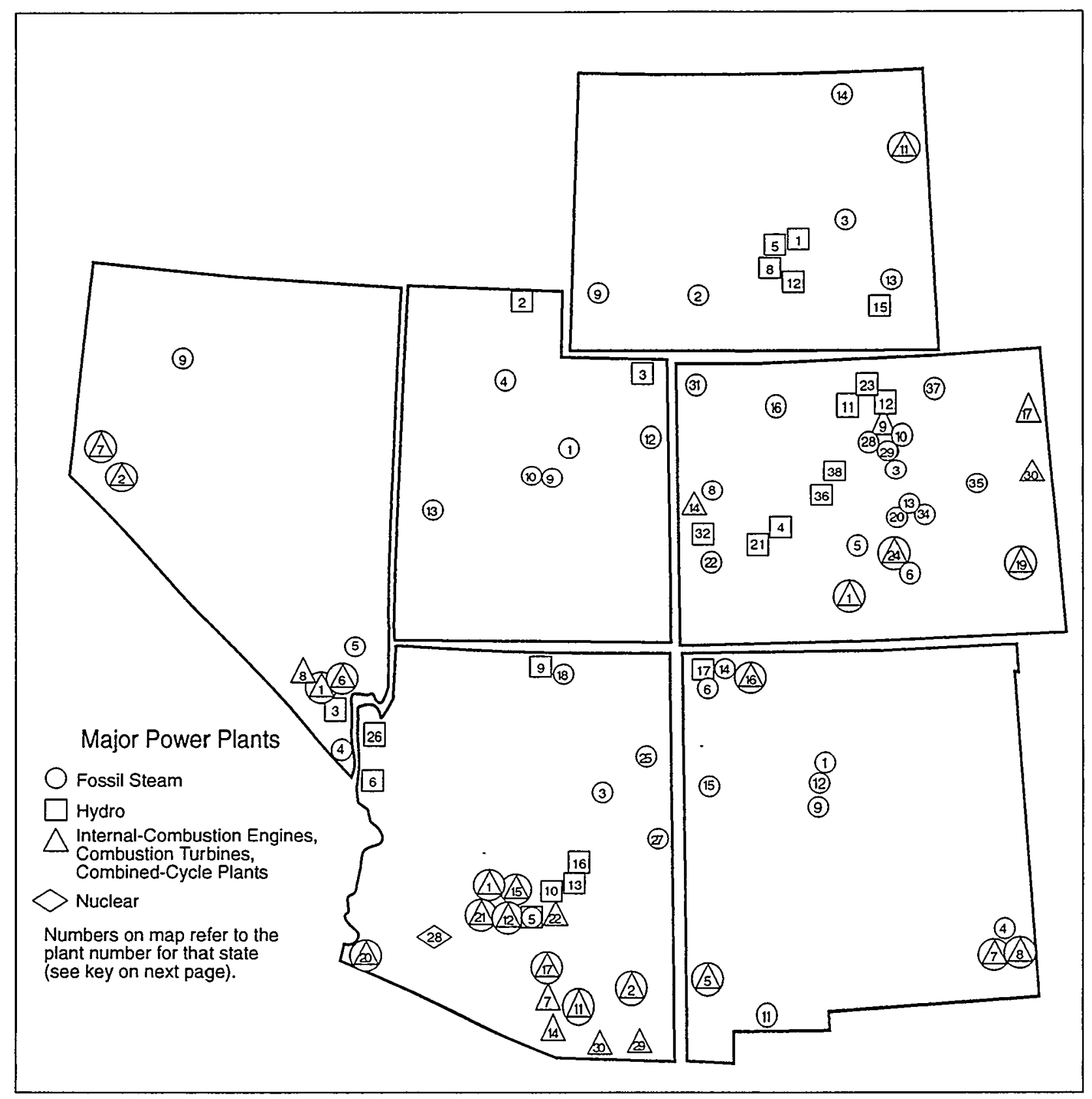

FIGURE 2 Major Electric Power Plants in the Six-State Study Region (see Table 3 for key to facilities) (Source: Adapted from Electrical World 1993) 
TABLE 3 Key to Figure 2

\begin{tabular}{|c|c|c|c|c|c|c|}
\hline \multicolumn{2}{|c|}{ State/Power Plant } & Type of Plant & MW & State/Power Plant & Type of Plant & MW \\
\hline \multicolumn{4}{|c|}{ Arizona } & \multicolumn{3}{|l|}{ Colorado (Cont.) } \\
\hline \multirow{2}{*}{\multicolumn{2}{|c|}{1 Aqua Fria }} & Fossil steam & 390 & 30 Burlington & Combustion turbine & 118 \\
\hline & & Combustion turbine & 223 & 31 Craig & Fossil steam & 1,284 \\
\hline \multirow[t]{3}{*}{2} & Apache & Fossil steam & 399 & 32 Crystal & Hydroelectric & 29 \\
\hline & & Combined cycle & 80 & 34 Nixon & Fossil steam & 207 \\
\hline & & Combustion turbine & 84 & 35 Pawnee & Fossil steam & 500 \\
\hline 3 & Cholla & Fossil steam & 1,156 & 36 Mt. Elbert & Hydroelectric & 200 \\
\hline \multirow[t]{2}{*}{5} & Cross Cut & Fossil steam & 30 & 37 Rawhide & Fossil steam & 255 \\
\hline & & Hydroelectric & $\mathbf{3}$ & 38 Green Mountain & Hydroelectric & 26 \\
\hline 6 & Davis & Hydroelectric & 225 & & & \\
\hline 7 & De Moss-Petrie & Combustion turbine & 66 & Nevada & & \\
\hline 8 & Glen Canyon & Hydroelectric & 1,267 & 1 Clark & Fossil steam & 190 \\
\hline 10 & Horse Mesa & Hydroelectric & 130 & & Combustion turbine & 270 \\
\hline \multirow[t]{2}{*}{11} & Irvington & Fossil steam & 505 & 2 Fort Churchill & Fossil steam & 220 \\
\hline & & Combustion turbine & 81 & 3 Hoover & Hydroelectric & 676 \\
\hline \multirow[t]{2}{*}{12} & Kyrene & Fossil steam & 108 & 4 Mohave & Fossil steam & 1,636 \\
\hline & & Combustion turbine & 227 & 5 Reid Garder & Fossil steam & 342 \\
\hline 13 & Mormon Flat & Hydroelectric & 58 & 6 Sunrise & Fossil steam & 82 \\
\hline 14 & North Loop & Combustion turbine & 108 & & Combustion turbine & 75 \\
\hline \multirow[t]{2}{*}{15} & Ocotillo & Fossil steam & 220 & 7 Tracy & Fossil steam & 243 \\
\hline & & Combustion turbine & 174 & & Combustion turbine & 25 \\
\hline 16 & Roosevelt & Hydroelectric & 35 & 8 Westside & Internal combustion & 32 \\
\hline \multirow[t]{2}{*}{17} & Saguaro & Fossil steam & 225 & 9 Valmy & Fossil steam & 254 \\
\hline & & Combustion turbine & 114 & & & \\
\hline 18 & Navajo & Fossil steam & 2,410 & New Mexico & & \\
\hline 20 & Yuma Axis & Fossil steam & 75 & I Algodones & Fossil steam & 51 \\
\hline & & Combustion turbine & 148 & 4 Cunningham & Fossil steam & 265 \\
\hline 21 & Phoenix & Fossil steam & 75 & 5 Lordsburg & Fossil steam & 37 \\
\hline & & Combustion turbine & 106 & & Combined cycle & 5 \\
\hline & & Combined cycle & 396 & & Combustion turbine & 13 \\
\hline 22 & Santan & Combustion turbine & 414 & 6 Four Corners & Fossil steam & 2,268 \\
\hline 25 & Coronado & Fossil steam & 821 & 7 North Lovington & Fossil steam & 49 \\
\hline 26 & Hoover & Hydroelectric & 671 & & Internal combustion & 19 \\
\hline 27 & Springerville & Fossil steam & 794 & 8 Maddox & Fossil steam & 114 \\
\hline 28 & Palo Verde & Nuclear & 3,810 & & Combustion turbine & 66 \\
\hline 29 & Douglas & Combustion turbine & 26 & 9 Person & Fossil steam & 120 \\
\hline 30 & Valencia & Combustion turbine & 50 & 11 Rio Grande & Fossil steam & 266 \\
\hline & & Internal combustion & 4 & 12 Reeves & Fossil steam & 175 \\
\hline & & & & 14 San Juan & Fossil steam & 1,572 \\
\hline Colora & & & & 15 Plains Escalante & Fossil steam & 233 \\
\hline 1 & Alamosa & Fossil steam & 20 & 16 Animas & Fossil steam & 32 \\
\hline & & Combustion turbine & 58 & & Internal combustion & 2 \\
\hline 2 & Arapahoe & Fossil steam & 251 & 17 Navajo & Hydroelectric & 30 \\
\hline 4 & Blue Mesa & Hydroelectric & 60 & & & \\
\hline 5 & Clark & Fossil steam & 39 & Utah & & \\
\hline 6 & Comanche & Fossil steam & 778 & 1 Carbon & Fossil steam & 189 \\
\hline 7 & Cabin Creek & Hydroelectric & 300 & 2 Cutler & Hydroelectric & 30 \\
\hline 8 & Cameo & Fossil steam & 75 & 3 Flaming Gorge & Hydroelectric & 108 \\
\hline 9 & Fort Lupton & Combustion turbine & 110 & 4 Gadsby & Fossil steam & 252 \\
\hline 10 & Cherokee & Fossil steam & 802 & 9 Huntington Canyon & Fossil steam & 893 \\
\hline 11 & Estes & Hydroelectric & 45 & 10 Hunter & Fossil steam & 1,338 \\
\hline 12 & Flatiron & Hydroelectric & 74 & 12 Bonzana & Fossil steam & 400 \\
\hline 13 & Birdsall & Fossil steam & 63 & 13 Intermountain & Fossil steam & 1,522 \\
\hline 14 & Fruita & Combustion turbine & 29 & & & \\
\hline 16 & Hayden & Fossil steam & 465 & Wyoming & & \\
\hline 17 & Republican River & Combustion turbine & 225 & 1 Alcova & Hydroelectric & 36 \\
\hline 19 & Lamar & Fossil steam & 35 & 2 Bridger & Fossil steam & 2,024 \\
\hline & & Internal combustion & 2 & 3 Johnston & Fossil sleam & 788 \\
\hline 20 & Drake & Fossil steam & 282 & 5 Fremont Canyon & Hydroelectric & 48 \\
\hline & & Combustion turbine & 66 & 8 Kortes & Hydroclectric & 36 \\
\hline 21 & Morrow Point & Hydroelectric & 120 & 9 Naughton & Fossil stenm & 711 \\
\hline 22 & Nucla & Fossil steam & 38 & 11 Osage & Fossil steam & 36 \\
\hline 23 & Pole Hill & Hydroelectric & 33 & & Internal combustion & 1 \\
\hline 24 & Pueblo & Fossil steam & 23 & 12 Seminoe & Hydroelectric & 45 \\
\hline & & Internal combustion & 10 & 13 Laramie & Fossil steam & 1,650 \\
\hline 28 & Valmont & Fossil steam & 282 & 14 Wyodak & Fossil steam & 331 \\
\hline & & Combustion turbine & 66 & 15 Glendo & Hydroelectric & 38 \\
\hline 29 & Zuni & Fossil steam & 115 & & & \\
\hline
\end{tabular}


TABLE 4 Annual Emissions of $\mathrm{SO}_{2}$, $\mathrm{NO}_{x}$, and VOCs from Electric Utility and Other Sectors within the Six-State Study Region, $1981-1990^{\mathrm{a}}$

\begin{tabular}{|c|c|c|c|c|c|c|c|c|c|c|}
\hline \multirow{2}{*}{$\begin{array}{l}\text { Pollutant/ } \\
\text { Sector }\end{array}$} & \multicolumn{10}{|c|}{ Emissions by Year ( $10^{3}$ tons) } \\
\hline & 1981 & 1982 & 1983 & 1984 & 1985 & 1986 & 1987 & 1988 & 1989 & 1990 \\
\hline \multicolumn{11}{|l|}{$\mathrm{SO}_{2}$} \\
\hline Electric utility & 458 & 465 & 451 & 474 & 397 & 359 & 379 & 459 & 469 & 410 \\
\hline Others & 1,571 & 1,036 & 1,112 & 1,074 & 971 & 870 & 601 & 519 & 445 & 429 \\
\hline Total ${ }^{b}$ & 2,029 & 1,501 & 1,563 & 1,548 & 1,368 & 1,229 & 980 & 979 & 914 & 839 \\
\hline \multicolumn{11}{|l|}{$\mathrm{NO}_{\mathrm{x}}$} \\
\hline Electric utility & 482 & 499 & 484 & 521 & 532 & 509 & 570 & 623 & 675 & 979 \\
\hline Others & 839 & 880 & 940 & 969 & 753 & 710 & 733 & 743 & 769 & 773 \\
\hline Total $^{b}$ & 1,322 & 1,380 & 1,424 & 1,490 & 1,284 & 1,219 & 1,304 & 1,366 & 1,444 & 1,752 \\
\hline \multicolumn{11}{|l|}{ VOCs } \\
\hline Electric utility & 3 & 3 & 3 & 3 & 3 & 3 & 3 & 3 & 3 & 3 \\
\hline Others & 1,024 & 980 & 972 & 973 & 878 & 830 & 841 & 864 & 831 & 802 \\
\hline Total $^{b}$ & 1,026 & 983 & 975 & 976 & 881 & 833 & 845 & 867 & 835 & 805 \\
\hline
\end{tabular}

a The six states are Arizona, Colorado, Nevada, New Mexico, Utah, and Wyoming.

b Individual values may not add up to the total because of rounding.

Source: Cilek (1993). 
accounted for a significant portion (36\%) of the region's total human-related emissions in 1990 , but represented only a small fraction (2\%) from the emissions of the United States as a whole (Table 5).

Ambient air quality data from monitoring stations located within the study region for 1987-1990 show that, except for scattered industrial sites and the major cities of the region, the air quality in the region is quite good. During this period, nitrogen dioxide $\left(\mathrm{NO}_{2}\right)$ and lead $(\mathrm{Pb})$ levels were substantially below the NAAQS throughout the region. Carbon monoxide ( $\mathrm{CO}$ ) levels have remained fairly constant in the major cities of the region over the same period. Regionwide, $\mathrm{O}_{3}$ concentrations decreased slightly, but $\mathrm{SO}_{2}$ and particulate matter (PM) concentrations increased slightly. Figures A.1 through A. 7 in the appendix show the location of all ambient air quality monitoring stations reporting to the six states in 1989 and indicate which stations reported ambient concentrations that exceeded the applicable standards for that year.

Visibility impairment is caused by light scattering and absorption by particles (primarily fine particles) and, to a lesser extent, $\mathrm{NO}_{2}$ present in the lower atmosphere. The

TABLE 5 Annual Emissions of $\mathrm{CO}_{2}$ from Electric Utility and Other Sectors within the Six-State Study Region and the United States, 1981-1990

\begin{tabular}{|c|c|c|c|c|c|c|}
\hline \multirow[b]{3}{*}{ Year } & \multicolumn{6}{|c|}{ Emissions $\left(10^{6}\right.$ tons as carbon) } \\
\hline & \multicolumn{3}{|c|}{ Six States ${ }^{a}$} & \multicolumn{3}{|c|}{ United States } \\
\hline & $\begin{array}{c}\text { Electric } \\
\text { Utility }\end{array}$ & Others & Total $^{\mathrm{b}}$ & $\begin{array}{c}\text { Electric } \\
\text { Utility }\end{array}$ & Others & Total $^{\mathrm{b}}$ \\
\hline 1981 & 39 & 78 & 117 & 473 & 1,830 & 2,303 \\
\hline 1982 & 40 & 76 & 115 & 447 & 1,715 & 2,162 \\
\hline 1983 & 38 & 75 & 114 & 459 & 1,671 & 2,130 \\
\hline 1984 & 42 & 78 & 120 & 479 & 1,770 & 2,249 \\
\hline 1985 & 44 & 75 & 120 & 492 & 1,743 & 2,235 \\
\hline 1986 & 41 & 74 & 115 & 488 & 1,749 & 2,237 \\
\hline 1987 & 47 & 75 & 122 & 506 & 1,806 & 2,313 \\
\hline 1988 & 51 & 80 & 131 & 531 & 1,892 & 2,423 \\
\hline 1989 & 52 & 81 & 134 & 539 & 1,904 & 2,443 \\
\hline 1990 & 53 & 93 & 145 & 531 & 1,901 & 2,432 \\
\hline
\end{tabular}

a The six states are Arizona, Colorado, Nevada, New Mexico, Utah, and Wyoming.

b Individual values may not add up to the total because of rounding.

Source: Cilek (1993). 
largest single factor controlling the seasonal and long-term variations in visibility in the Colorado River Basin is the concentration of fine, airborne sulfate aerosols (Malm 1989). The region's four largest sources of fine sulfates identified by the National Park Service for 1983-1985 were, in descending order, Southern California, Monterrey (Mexico), the coalburning generating stations in the Four Corners ${ }^{2}$ region, and the copper smelters in New Mexico and southeastern Arizona (Malm et al. 1990). It is now widely recognized that carbonaceous particles such as soot also play an important role in impairment of visibility. However, the dominant source categories of carbonaceous particle emissions are on-road and off-road mobile sources and residential fuel combustion sources. Electric utilities are a very minor source of carbonaceous particles.

Visibility in the six-state study region is currently the best in the contiguous United States. The Four Corners region has summer visibility of over $120 \mathrm{mi}$ (Figure 3). Except for Arizona, the remainder of the study region has summer visibility above $110 \mathrm{mi}$. In Arizona, the summer visibility decreases from $120 \mathrm{mi}$ in the northeast corner to $60 \mathrm{mi}$ in the southwest corner bordering California. Throughout the region, visibility varies greatly with season. In winter, visibility is approximately 1.5 times better than in summer. Long-term trends for the region indicate that, overall, visibility has decreased since the mid-1950s, with some recovery made during the 1970s and essentially no change in the 1980s (Malm 1989). The study region has a large number of Federal Class I areas for which the EPA has determined that visibility is an important value (Figure 4).

\subsection{ACOUSTIC ENVIRONMENT}

The important noise sources at the major hydroelectric generating plants considered in this study (Glen Canyon, Flaming Gorge, Blue Mesa, Morrow Point, and Crystal) include turbine generators, step-up transformers, and substation transformers. Because turbine generators and step-up transformers are located near canyon bottoms and because the turbine generators are also enclosed inside concrete plant buildings, ${ }^{3}$ they contribute minimally to the environmental noise levels in areas beyond canyon rims. Noise regulations and guidelines applicable to the study region, existing acoustic environments in the vicinity of these hydroelectric plants, and estimated noise levels due to the hydroelectric plant noise sources are described in Sections 2.3.1, 2.3.2, and 2.3.3, respectively.

\subsubsection{Noise Regulations and Guidelines}

The Noise Control Act of 1972, together with its subsequent amendments (Quiet Communities Act of 1978, Title 42, United States Code, Parts 4901-4918), leaves it to the

2 The point where the four states of Arizona, Colorado, New Mexico, and Utah meet.

3 In the case of Morrow Point, the turbine-generator and the step-up transformer are located inside the rock cavity near the bottom of the canyon. 


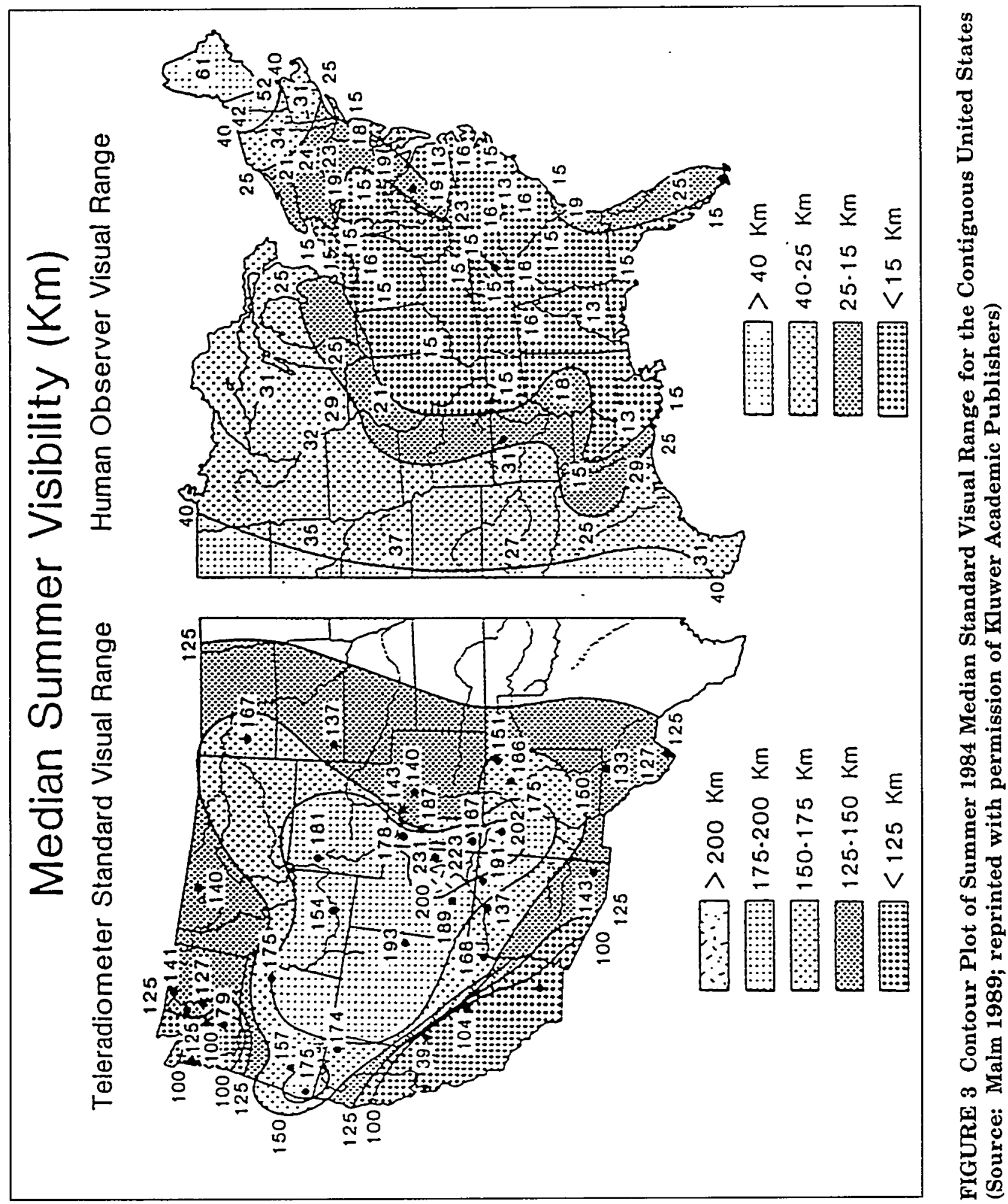




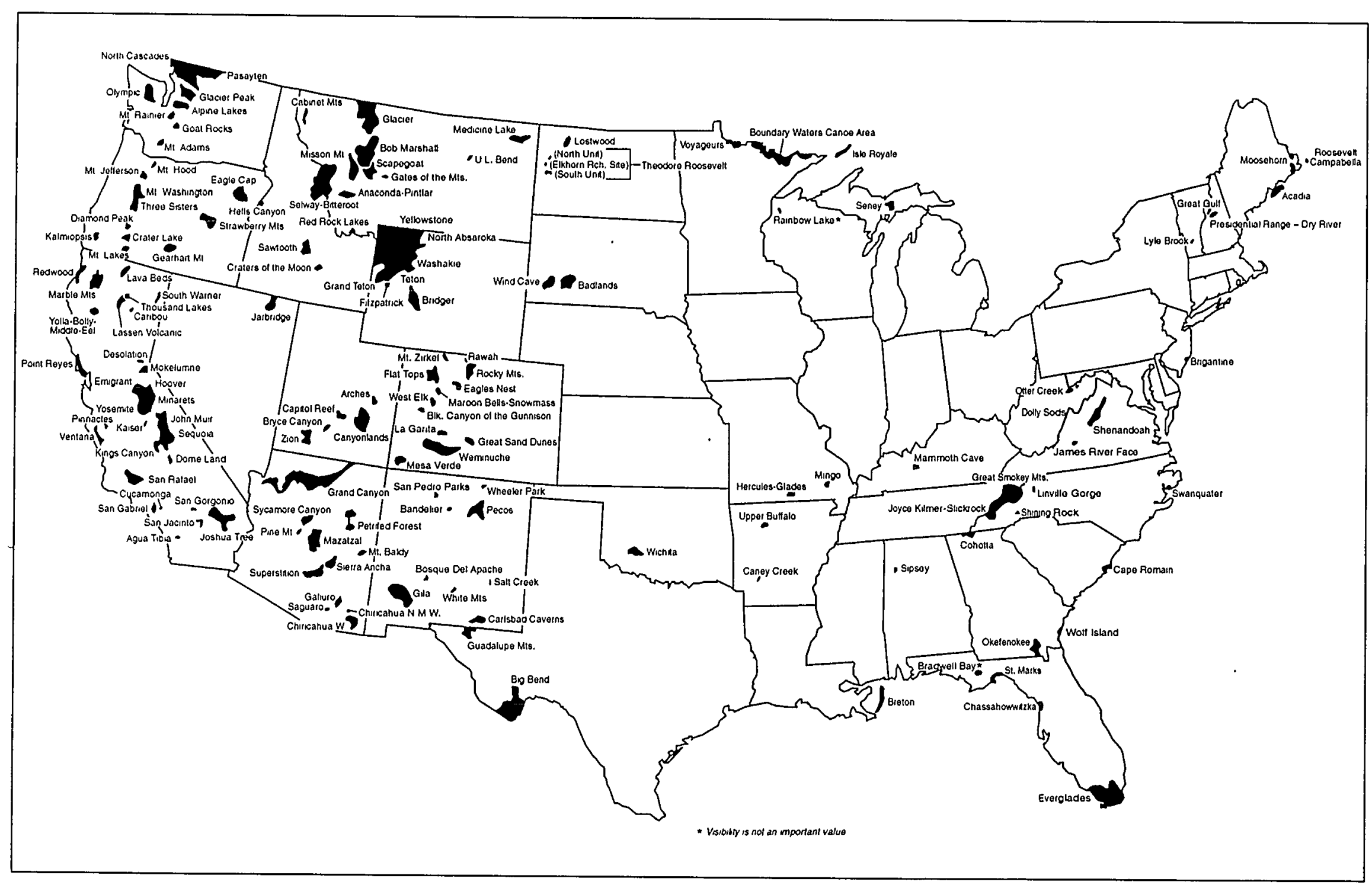

FIGURE 4 Federal Class I Air Quality Areas in the Contiguous United States (Source: Adapted from EPA 1979) 
states to regulate environmental noise and directs government agencies to comply with local community noise statutes and regulations. Of the six states within the study region, Colorado is the only state with quantitative noise-limit regulations. The maximum permissible noise limits for the various classes of source areas under the Colorado Noise Abatement Law are listed in Table 6.

The EPA guideline recommends an $\mathrm{L}_{\mathrm{dn}}{ }^{4}$ of $55 \mathrm{dBA},{ }^{5}$ which is sufficient to protect the public from the effect of broad-band environmental noise in typically quiet outdoor and residential areas (EPA 1974). For protection against hearing loss in the general population from nonimpulsive noise, the EPA guideline recommends an $\mathrm{L}_{\mathrm{eq}}{ }^{6}$ of $70 \mathrm{dBA}$ or less over a 40-year period.

TABLE 6 State of Colorado Regulations on Maximum Permissible Noise Levels

\begin{tabular}{lcc}
\hline & \multicolumn{2}{c}{ Maximum Permissible Noise Level $^{\mathrm{a}}(\mathrm{dBA})$} \\
\cline { 2 - 3 } Zone & 7 a.m. to 7 p.m. $^{\mathrm{b}}$ & 7 p.m. to next 7 a.m. \\
\hline Residential & 55 & 50 \\
Commercial & 60 & 55 \\
Light industrial & 70 & 65 \\
Industrial & 80 & 75 \\
\hline
\end{tabular}

a At a distance of $25 \mathrm{ft}$ or more from the property line. Periodic, impulsive, or shrill noises are considered a public nuisance when such noises are at a level of $5 \mathrm{dBA}$ less than thase listed.

b For a period not to exceed 15 minutes in any one hour, the noise level may be exceeded by $10 \mathrm{dBA}$.

Source: Colorado Revised Statutes, Title 25 - Health, Article 12 - Noise Abatement.

$4 \mathrm{~L}_{\mathrm{dn}}$ is the day-night weighted equivalent sound level.

$5 \mathrm{dBA}$ is a unit of weighted sound-pressure level, measured by the use of the metering characteristics and the "A" weighting specified in the American National Standard Specification for Sound Level Meters ANSI S1.4-1983 and Amendment S1.4A-1985 (Acoustical Society of America 1983, 1985).

$6 \mathrm{~L}_{\mathrm{eq}}$ is the equivalent steady sound level that, if continuous during a specific time period, would contain the same total energy as the actual time-varying sound. For example, $\mathrm{L}_{\mathrm{eq}}(1 \mathrm{~h})$ is the 1 -hour equivalent sound level. 


\subsubsection{Existing Acoustic Environment}

\subsubsection{Glen Canyon Dam}

The acoustic environment in areas away from the major noise sources at the Glen Canyon power plant is that of a rural location, with typical residual sound levels ${ }^{7}$ of about 30 to $35 \mathrm{dBA}$ (Liebich and Cristoforo 1988). However, close to the boundary of the transformer substation, the estimated residual environmental noise level is about $55 \mathrm{dBA}$ (Table 7).

The noise-sensitive receptors nearest to the transformer substation at the Glen Canyon power plant are the residences located along the northwestern perimeter of the city of Page, approximately $1.1 \mathrm{mi}$ east of the substation. If the Glen Canyon power plant was not present, these residences would have a residual nighttime sound level typical of rural communities near a lightly traveled highway, approximately $30 \mathrm{dBA}$ (Liebich and Cristoforo 1988). However, acoustic emissions from the noise sources at the Glen Canyon power plant are estimated to raise the residual background environmental noise level in the residential area up to about $39 \mathrm{dBA}$ (Table 8 ).

The ambient environmental noise level at these residences is substantially increased at times when traffic is passing on nearby roadways. An automobile can produce a momentary level of up to $77 \mathrm{dBA}$ when passing along a roadway at a distance of $50 \mathrm{ft}$ from a receptor. A large, heavily loaded tractor-trailer truck can create maximum levels as high as $87 \mathrm{dBA}$ when passing at a distance of $50 \mathrm{ft}$ (Flynn 1979; Fuller and Brown 1981). At such times, vehicular noise completely masks (makes inaudible) all other environmental background noise at these residences, including the levels attributable to noise sources at the Glen Canyon power plant.

\subsubsection{Flaming Gorge Dam}

The acoustic environment in areas away from the major noise sources at the Flaming Gorge hydroelectric plant is that of a remote rural-to-wilderness location, with typical residual sound levels of approximately 20 to $25 \mathrm{dBA}$ (Liebich and Cristoforo 1988). However, close to the boundary of the transformer substation, the residual environmental noise level is estimated to be about $44 \mathrm{dBA}$ (Table 7).

The noise-sensitive receptors closest to the transformer substation at the Flaming Gorge power plant are the Arch Dam and Deer Run campgrounds, approximately 0.9 mi east and $1.1 \mathrm{mi}$ west-southwest of the transformer substation, respectively. If the Flaming Gorge

7 A residual level represents a low-limit value to which the ambient environmental noise drops frequently, but below which it seldom goes. 
TABLE 7 Predicted and Measured Residual Noise Levels and Spectra at Sensitive Receptors in the Vicinity of the Glen Canyon and Flaming Gorge Plants and the Curecanti Substation Transformer

\begin{tabular}{|c|c|c|c|c|c|c|c|}
\hline \multirow{2}{*}{$\begin{array}{l}\text { Noise Source/ } \\
\text { Receptor }\end{array}$} & \multirow{2}{*}{$\begin{array}{l}\text { Level } \\
\text { Predicted or } \\
\text { Measured }\end{array}$} & \multirow{2}{*}{$\begin{array}{l}\text { A-Weighted } \\
\text { Noise Level } \\
\text { (dBA) }\end{array}$} & \multicolumn{5}{|c|}{ Noise Levels $(\mathrm{dB})$ at Octave Band Frequency } \\
\hline & & & $31 \mathrm{~Hz}$ & $63 \mathrm{~Hz}$ & $125 \mathrm{~Hz}$ & $250 \mathrm{~Hz}$ & $500 \mathrm{~Hz}$ \\
\hline \multirow{3}{*}{$\begin{array}{l}\text { Glen Canyon } \\
\text { Closest residence }\end{array}$} & & & & & & & \\
\hline & Predicted $^{\mathrm{a}}$ & $\begin{array}{c}29.9 \\
(21 \text { to } 37)^{b}\end{array}$ & - & - & 44.5 & 32.1 & 21.9 \\
\hline & Measured $^{c}$ & 27.9 & 48.0 & 37.0 & 32.7 & 30.3 & 24.0 \\
\hline Substation entrance & Predicted $^{d}$ & 54.7 & - & - & 68.1 & 56.1 & 48.2 \\
\hline \multirow[t]{2}{*}{$\begin{array}{l}\text { Flaming Gorge } \\
\text { Arch Dam campground }\end{array}$} & Predicted $^{a}$ & $\begin{array}{c}8.2 \\
(-2 \text { to } 29)^{b}\end{array}$ & - & - & 23.5 & 8.4 & -3.4 \\
\hline & Measured $^{c}$ & 19.6 & 28.1 & 26.5 & 24.6 & 21.7 & 16.9 \\
\hline \multirow[t]{2}{*}{ Deer Run campground } & Predicted $^{a}$ & $\begin{array}{c}0.5 \\
(-7 \text { to } 25)^{b}\end{array}$ & - & - & 14.5 & 4.6 & -10.1 \\
\hline & Measured ${ }^{c}$ & 24.6 & 29.7 & 29.3 & 27.1 & 25.1 & 23.0 \\
\hline \multirow[t]{2}{*}{ Substation perimeter } & Predicted $^{d}$ & 44.4 & - & - & 57.8 & 45.7 & 37.9 \\
\hline & Measured $^{\mathfrak{C}}$ & 40.0 & 40.7 & 47.3 & 45.8 & 31.8 & 38.5 \\
\hline Substation entrance & Predicted $^{d}$ & 57.1 & -- & $\cdots$ & 70.5 & 58.5 & 50.6 \\
\hline $\begin{array}{l}\text { Curecanti } \\
\text { Closest residence, } 0.25 \mathrm{mi} \\
\text { from substation }\end{array}$ & Predicted $^{\mathrm{a}}$ & $\begin{array}{c}32.7 \\
(25 \text { to } 36)^{b}\end{array}$ & - & - & - & 48.7 & 24.1 \\
\hline \multirow{2}{*}{$\begin{array}{l}400 \mathrm{ft} \text { from substation } \\
\text { toward closest residence }\end{array}$} & Predicted $^{d}$ & 38.0 & $\cdot$ & - & 51.2 & 39.4 & 31.5 \\
\hline & Measured $^{\mathfrak{c}}$ & 40.2 & 35.4 & 37.9 & 52.5 & 35.0 & 32.1 \\
\hline $\begin{array}{l}\text { Substation entrance west of } \\
\text { transformer }\end{array}$ & Predicted $^{d}$ & 44.1 & - & - & 57.5 & 45.5 & 37.6 \\
\hline
\end{tabular}

a Predicted with the ENM 1.2 model for weather conditions of temperature $(\mathrm{T})=25^{\circ} \mathrm{C}$; relative humidity $(\mathrm{RH})=50 \%$, wind speed $=0 \mathrm{~m} / \mathrm{s}$, and vertical temperature gradient $=-1.0^{\circ} \mathrm{C} / 100 \mathrm{~m}$.

$b$ The range of transformer noise predicted under a range of weather conditions (see Table 8).

c Adjusted from field data measured with a transformer noise prediction procedure (Gordon et al. 1978, 1980), which is equivalent to an assumption that only spherical spreading of the disturbance is significant close to the transformer (i.e., climate and ground effects are ignored).

d Predicted with a transformer noise prediction procedure (Gordon et al. 1978, 1980), which assumes that only spherical spreading of noise is significant at receptors close to the transformer. 
TABLE 8 Predicted Noise Levels at the Sensitive Receptors Contributed by Step-up and Substation Transformers at the Glen Canyon and Flaming Gorge Plants and the Curecanti Substation Transformer

\begin{tabular}{|c|c|c|c|c|c|}
\hline \multirow[b]{2}{*}{ Noise Source/Receptor } & \multirow[b]{2}{*}{$\begin{array}{l}\text { Weather } \\
\text { Conditions }^{\mathrm{a}}\end{array}$} & \multicolumn{4}{|c|}{$\begin{array}{l}\text { Noise Level (dBA) at } \\
\text { Receptor Location }\end{array}$} \\
\hline & & $\begin{array}{l}\text { Step-up } \\
\text { Transformers }\end{array}$ & $\begin{array}{l}\text { Substation } \\
\text { Transformers }\end{array}$ & Both $^{b}$ & $\begin{array}{l}\text { Both }^{\mathrm{b}} \text { plus } \\
\text { Residual Sound }\end{array}$ \\
\hline \multicolumn{6}{|l|}{ Glen Canyon } \\
\hline Closest residence & 1 & 29.2 & 36.2 & 37.0 & 39.1 \\
\hline \multirow[t]{4}{*}{ in Page, Arizona } & 2 & 18.5 & 33.0 & 33.2 & 37.2 \\
\hline & 3 & 9.5 & 29.8 & 29.9 & 36.2 \\
\hline & 4 & 4.0 & 24.6 & 24.7 & 35.4 \\
\hline & 5 & 0.1 & 20.9 & 20.9 & 35.2 \\
\hline \multicolumn{6}{|l|}{ Flaming Gorge } \\
\hline \multirow[t]{5}{*}{ Arch Dam campground } & 1 & 9.1 & 28.5 & 28.6 & 30.2 \\
\hline & 2 & 6.4 & 21.9 & 22.0 & 26.8 \\
\hline & 3 & 3.5 & 6.3 & 8.2 & 25.1 \\
\hline & 4 & -2.0 & -1.8 & 1.1 & 25.0 \\
\hline & 5 & -5.6 & -4.4 & -1.9 & 25.0 \\
\hline \multirow[t]{5}{*}{ Deer Run campground } & 1 & 1.2 & 25.4 & 25.4 & 28.2 \\
\hline & 2 & -1.2 & 14.7 & 14.8 & 25.4 \\
\hline & 3 & -4.0 & -1.3 & 0.5 & 25.0 \\
\hline & 4 & -9.6 & -5.6 & -4.1 & 25.0 \\
\hline & 5 & -13.7 & -8.6 & -7.4 & 25.0 \\
\hline \multicolumn{6}{|l|}{ Curecanti } \\
\hline \multirow{5}{*}{$\begin{array}{l}\text { Closest residence, } 0.20 \mathrm{ml} \\
\text { from substation }\end{array}$} & 1 & - & 35.6 & 35.6 & 36.7 \\
\hline & 2 & - & 34.6 & 34.6 & 35.9 \\
\hline & 3 & - & 32.7 & 32.7 & 34.6 \\
\hline & 4 & - & 28.4 & 28.4 & 32.3 \\
\hline & 5 & - & 25.2 & 25.2 & 31.2 \\
\hline
\end{tabular}

a The weather conditions used in predicting noise-level contributions with the ENM are as follows:

\begin{tabular}{|c|c|c|c|}
\hline $\begin{array}{l}\text { Weather } \\
\text { Condition } \\
\end{array}$ & $\begin{array}{l}\text { Wind Speed } \\
(\mathrm{m} / \mathrm{s})\end{array}$ & Wind Direction & $\begin{array}{l}\text { Vertical Temperature } \\
\text { Gradient }\left({ }^{\circ} \mathrm{C} / 100 \mathrm{~m}\right) \\
\end{array}$ \\
\hline 1 & 5.0 & Source to receptor & 1.0 \\
\hline 2 & 2.5 & Source to receptor & 1.0 \\
\hline 3 & 0 & Not applicable & -1.0 \\
\hline 4 & -2.5 & Receptor to source & -1.0 \\
\hline 5 & -5.0 & Receptor to source & -1.0 \\
\hline
\end{tabular}

The ambient temperature and relative humidity are assumed to be $25^{\circ} \mathrm{C}$ and $50 \%$, respectively.

b Represents the logarithmic or energy sum of the noise contributions from both the step-up and substation transformers. 
power plant was not present, these campgrounds would have a residual nighttime sound level typical of remote rural-to-wilderness areas, approximately $20 \mathrm{dBA}$ (Liebich and Cristoforo 1988). Acoustic emissions from the noise sources at the Flaming Gorge power plant are estimated to raise the residual background environmental noise levels at these campgrounds up to about 30 and $28 \mathrm{dBA}$, respectively (Table 8).

The ambient environmental noise levels at these campgrounds are increased substantially at times when traffic is passing on nearby roadways. At such times, vehicular noise completely masks all other environmental background noise at the campgrounds, including the levels attributable to noise sources at the Flaming Gorge power plant.

\subsubsection{Aspinall Unit}

The acoustic environment in areas away from the major noise sources of the Aspinall Unit (Blue Mesa, Morrow Point, and Crystal dams) is that of a rural-to-remote-rural location, with typical residual sound levels of approximately 25 to $30 \mathrm{dBA}$ (Liebich and Cristoforo 1988). However, close to the boundary of the Curecanti substation (about $1.5 \mathrm{mi}$ south of the Morrow Point power plant), which serves the three power plants, the residual environmental noise level is estimated to be about $44 \mathrm{dBA}$ (Table 7).

The noise-sensitive receptor closest to the Curecanti substation is a trailer residence about $0.25 \mathrm{mi}$ northwest of the substation transformer. If the Curecanti substation was not present, the area surrounding the trailer residence would have residual nighttime sound levels typical of rural-to-remote-rural locations, approximately $25 \mathrm{dBA}$ (Liebich and Cristoforo 1988). The acoustic emissions from the substation transformer are estimated to raise the residual background environmental noise level at the trailer residence up to about $37 \mathrm{dBA}$ (Table 8).

The ambient environmental noise levels at the trailer residence are substantially increased at times when traffic is passing on nearby roadways. At such times, vehicular noise completely masks all other environmental background noise at the trailer residence, including the levels attributable to noise sources at the substation transformer.

\subsubsection{Estimated and Measured Noise Levels}

Major noise sources at the hydroelectric plants are turbine generators, step-up transformers, and substation transformers. The turbine generators at these plants are enclosed within concrete plant buildings near canyon bottoms, so they are expected to contribute minimally to the noise levels in areas beyond the canyon rims. The step-up transformers are located outside the plant buildings, except for the one at Morrow Point which is located in a cave. Because they are also situated near the canyon bottoms, these transformers are expected to contribute minimally to the noise levels beyond the canyon rims. To confirm these expectations, noise levels at sensitive receptors in the vicinity of these plants were estimated for both the step-up and substation transformers. Sound power levels 
of transformers were estimated with the empirical formulas developed by Gordon et al. (1978, 1980), and noise levels at receptor locations were estimated with the Environmental Noise Model (ENM 1.2), which accounts for the effects of distance, topography, ground cover, weather, and atmospheric conditions on noise propagation (Tonin 1985; RTA Software Pty 1989). Ambient noise levels at these receptors and other locations in the vicinity of substation transformers were also spot-checked during site visits conducted in May 1992 (Liebich 1992).

Characteristics of the transformers are presented in Table 9, including MVA rating, location, and estimated sound power level at a reference distance of $3 \mathrm{ft}$. Distances between the transformers and sensitive receptors, and the topographic and ground-cover features of the intervening grounds, are given in Table 10. The noise spectra of estimated and measured noise levels at the sensitive receptors and the noise contributions from the step-up and substation transformers at sensitive receptors are listed in Tables 7 and 8, respectively. Table 7 shows that the measured noise levels in dBA generally fall within the range of predicted data. The data in Table 8 indicate that the noise produced by the step-up transformers at the base of the Glen Canyon and Flaming Gorge dams had only minor impacts on the noise levels predicted for the receptors above the canyon rims, even when all such transformers were assumed to be in operation. The analysis predicted that in the cases when the transformer noise was predicted to be above $10 \mathrm{dBA}$, the contribution from step-up transformers was insignificant, amounting to additional noise increments of, at most, 0.8 and $0.1 \mathrm{dBA}$ at Glen Canyon and Flaming Gorge, respectively. Thus, noise levels at the sensitive receptors are expected to remain unchanged, regardless of the changes in operation at these hydroelectric facilities. 
TABLE 9 Characteristics of Transformers at the Glen Canyon, Flaming Gorge, and Aspinall Sites

\begin{tabular}{|c|c|c|c|c|c|c|c|c|c|}
\hline \multirow[b]{2}{*}{ Site } & \multicolumn{4}{|c|}{ Transformer Characteristics } & \multirow[b]{2}{*}{$\begin{array}{l}\text { Unit } \\
\text { Number }\end{array}$} & \multicolumn{4}{|c|}{$\begin{array}{c}\text { Sound Power Level (dB) at } 3 \mathrm{ft} \text { per Transformer } \\
\text { at } 120 \text { to } 480 \mathrm{~Hz}\end{array}$} \\
\hline & Location & Type $^{a}$ & $\begin{array}{l}\text { Rating } \\
\text { (MVA) }\end{array}$ & $\begin{array}{l}\mathrm{ETW}^{\mathrm{b}} \\
\text { (MVA) }\end{array}$ & & $120 \mathrm{~Hz}$ & $240 \mathrm{~Hz}$ & $360 \mathrm{~Hz}$ & $480 \mathrm{~Hz}$ \\
\hline \multirow[t]{2}{*}{ Glen Canyon } & Power plant ${ }^{c}$ & Two & 300 & 300 & 4 & 111.6 & 104.0 & 94.7 & 90.8 \\
\hline & Substation & $\begin{array}{l}\text { Auto } \\
\text { Auto } \\
\text { Auto } \\
\text { Auto } \\
\text { Auto } \\
\text { Two }\end{array}$ & $\begin{array}{r}350 \\
300 \\
80 \\
69 \\
39 \\
25\end{array}$ & $\begin{array}{r}175 \\
150 \\
40 \\
35 \\
20 \\
25\end{array}$ & $\begin{array}{l}1 \\
2 \\
1 \\
1 \\
1 \\
1\end{array}$ & $\begin{array}{l}113.7 \\
113.0 \\
107.3 \\
106.7 \\
104.3 \\
105.2\end{array}$ & $\begin{array}{r}101.7 \\
101.0 \\
95.2 \\
94.7 \\
92.2 \\
93.2\end{array}$ & $\begin{array}{l}92.3 \\
91.6 \\
85.9 \\
85.3 \\
82.9 \\
83.8\end{array}$ & $\begin{array}{l}88.4 \\
87.7 \\
82.0 \\
81.4 \\
79.0 \\
80.0\end{array}$ \\
\hline \multirow[t]{2}{*}{ Flaming Gorge } & Power plant & Two & 47 & 47 & 3 & 108.0 & 95.9 & 86.6 & 82.7 \\
\hline & Substation & $\begin{array}{l}\text { Auto } \\
\text { Auto } \\
\text { Two } \\
\text { Two }\end{array}$ & $\begin{array}{r}100 \\
19 \\
31 \\
5\end{array}$ & $\begin{array}{c}50 \\
9.5 \\
31 \\
5\end{array}$ & $\begin{array}{l}2 \\
1 \\
1 \\
1\end{array}$ & $\begin{array}{r}108.3 \\
101.0 \\
96.2 \\
98.3\end{array}$ & $\begin{array}{l}96.2 \\
89.0 \\
84.1 \\
86.2\end{array}$ & $\begin{array}{l}86.9 \\
79.6 \\
74.8 \\
76.9\end{array}$ & $\begin{array}{l}83.0 \\
75.8 \\
70.9 \\
73.0\end{array}$ \\
\hline \multicolumn{10}{|l|}{ Aspinall } \\
\hline Blue Mesa & Power plant & Two & 100 & 100 & 1 & 111.3 & 99.2 & 89.9 & 86.0 \\
\hline Morrow Point & Power plant & Two & 52 & 52 & 1 & 108.4 & 96.4 & 87.0 & 83.1 \\
\hline Crystal & Power plant & Two & 30 & 30 & 1 & 106.0 & 94.0 & 84.6 & 80.8 \\
\hline Curecanti & Substation & Auto & 75 & 37.5 & 1 & 107.0 & 95.0 & 85.6 & 81.7 \\
\hline
\end{tabular}

a Auto or two-winding.

b Estimated two-winding (ETW) MVA rating; calculated for autotransformers with the formula ETW $=(1-1 / n) \times$ MVA, where $\mathrm{n}$ is the step-up ratio of the transformer. For all transformers, an approximate value of $n=2$ was used (Franklin and Franklin 1983).

c Step-up transformers. 
TABLE 10 Elevations and Types of Ground Cover for the Areas from the Hydroelectric Plants and/or Their Substations to the Selected Receptor Locations

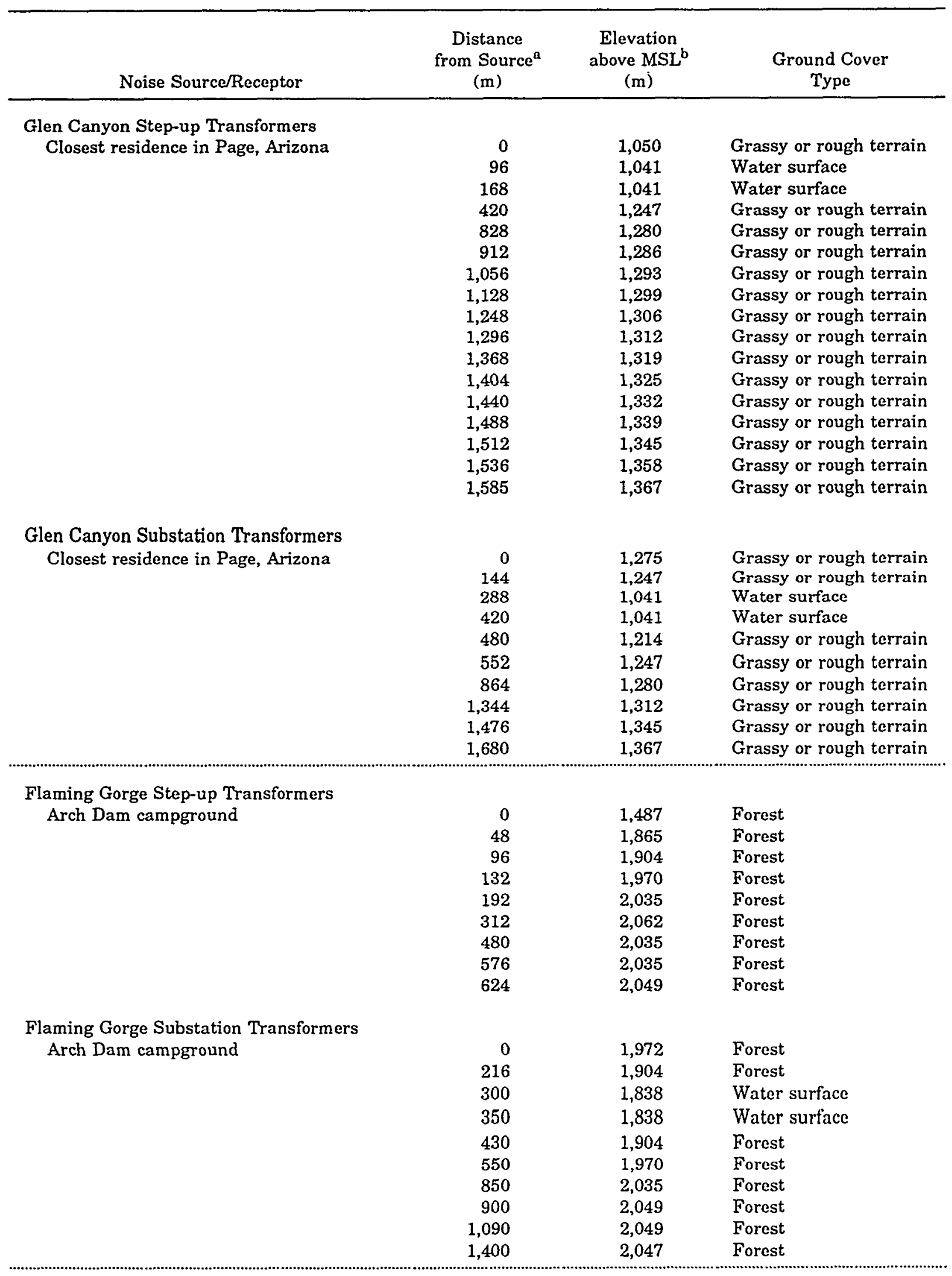


TABLE 10 (Cont.)

\begin{tabular}{|c|c|c|c|}
\hline Noise Source & $\begin{array}{c}\text { Distance } \\
\text { from Source } \\
(\mathrm{m})\end{array}$ & $\begin{array}{l}\text { Elevation } \\
\text { above MSL } \\
\text { (m) }\end{array}$ & $\begin{array}{l}\text { Ground Cover } \\
\text { Type }\end{array}$ \\
\hline \multicolumn{4}{|l|}{ Flaming Gorge Step-Up Transformers } \\
\hline \multirow{2}{*}{ Deer Run campground } & $\begin{aligned} 0 \\
79\end{aligned}$ & 1,854 & Forest \\
\hline & $\begin{array}{r}72 \\
120\end{array}$ & $\begin{array}{l}1,904 \\
1,970\end{array}$ & $\begin{array}{l}\text { Forest } \\
\text { Forest }\end{array}$ \\
\hline \multirow[t]{10}{*}{. } & 504 & 1,982 & Forest \\
\hline & 648 & 2,022 & Forest \\
\hline & 768 & 2,022 & Forest \\
\hline & 1,032 & 2,009 & Forest \\
\hline & 1,164 & 1,970 & Water surface \\
\hline & 1,296 & 1,970 & Water surface \\
\hline & 1,440 & 1,996 & Forest \\
\hline & 1,656 & 2,009 & Forest \\
\hline & 1,728 & 2,022 & Forest \\
\hline & 2,160 & 2,037 & Forest \\
\hline \multirow{10}{*}{$\begin{array}{l}\text { Flaming Gorge Substation Transformers } \\
\text { Deer Run campground }\end{array}$} & - & & \\
\hline & 0 & 1,972 & Forest \\
\hline & 216 & 2,022 & Forest \\
\hline & 576 & 2,022 & Forest \\
\hline & 720 & 1,970 & Water surface \\
\hline & 840 & 1,970 & Water surface \\
\hline & 912 & 1,996 & Forest \\
\hline & 1,200 & 2,009 & Forest \\
\hline & 1,270 & 2,022 & Forest \\
\hline & 1,680 & 2,037 & Forest \\
\hline \multicolumn{4}{|l|}{ Curecanti Substation Transformer } \\
\hline \multirow[t]{2}{*}{ Closest residence } & 0 & 2,313 & Grassy or rough terrain \\
\hline & 4 & 2,326 & Grassy or rough terrain \\
\hline
\end{tabular}

a Distance from the source to the receptor.

b $\mathrm{MSL}=$ mean sea level. 


\section{METHODOLOGY}

The methodology used to estimate potential impacts of Western's commitment-level alternatives and supply options (combination of hydroelectric plant operational scenarios) on local and regional air quality and regional emissions of greenhouse gases is described in this section. The components of air quality impact assessments are shown in Figure 5 - i.e., the assumptions, information used, and computations and analyses conducted. The major inputs to the analyses were the results of power systems modeling performed for the period of concern, 1993-2008 (Veselka et al. 1995). These inputs included (1) projected data for electric energy production and fuel use at existing and projected new generating units, (2) electric energy purchases by the region's utilities affected by Western's commitment-level alternatives, (3) Western's long-term and short-term firm sales commitments, and (4) Western's hydroelectric generation. The electric energy production and fuel use data for the existing and projected new units were projected with the Production and Capacity Expansion (PACE) model and the Spot Market Network Model (SMNM). The data on electric energy purchases by the region's utilities were developed with the Hydro Linear Programming Model on the basis of spot market prices projected by the SMNM. Western's short-term firm sales commitments were calculated using an algorithm that was based on hydrologic conditions and the long-term firm sales commitments defined by the commitmentlevel alternatives. Finally, the data for Western's hydroelectric generation were developed with the Hydro Linear Programming Model.

The power systems modeling was conducted for four commitment-level alternatives in selected years 1993, 1998, and 2008: (1) moderate capacity (1,291 MW) and high energy $(5,700 \mathrm{GWh})$ - i.e., no action; (2) high capacity (1,450 MW) and low energy (3,330 GWh); (3) low capacity (550 MW) and low energy (3,300 GWh); and (4) low capacity (625 MW) and high energy $(5,475 \mathrm{GWh})$. Three different supply options, consisting of combinations of operational scenarios at each of the three hydroelectric plants were paired in the power systems modeling. These supply options were defined as follows: (1) supply option A continuation of historical operations at Glen Canyon Dam, year-round high fluctuations at Flaming Gorge Dam, and seasonally adjusted high fluctuations at the Aspinall Unit; (2) supply option B - low fluctuations at Glen Canyon Dam, year-round high fluctuations at Flaming Gorge Dam, and seasonally adjusted high fluctuations at the Aspinall Unit; and (3) supply option $\mathrm{C}$ - seasonally adjusted steady flows at Glen Canyon Dam, Flaming Gorge Dam, and the Aspinall Unit.

The projected new additions to generating capacity for the region's 17 electric utility systems are listed in Table 11. Air pollutant emissions from individual generating units were estimated by multiplying the projected data for fuel use with the emission factors developed for each unit on the basis of quality of fuels used, boiler type, and emission control devices associated with each unit for 1992 (Kohout et al. 1990) or emission factors complying with the New Source Performance Standards in the case of projected new generating units (Tables 12 and 13). Air pollutant emissions associated with electric energy purchase by 


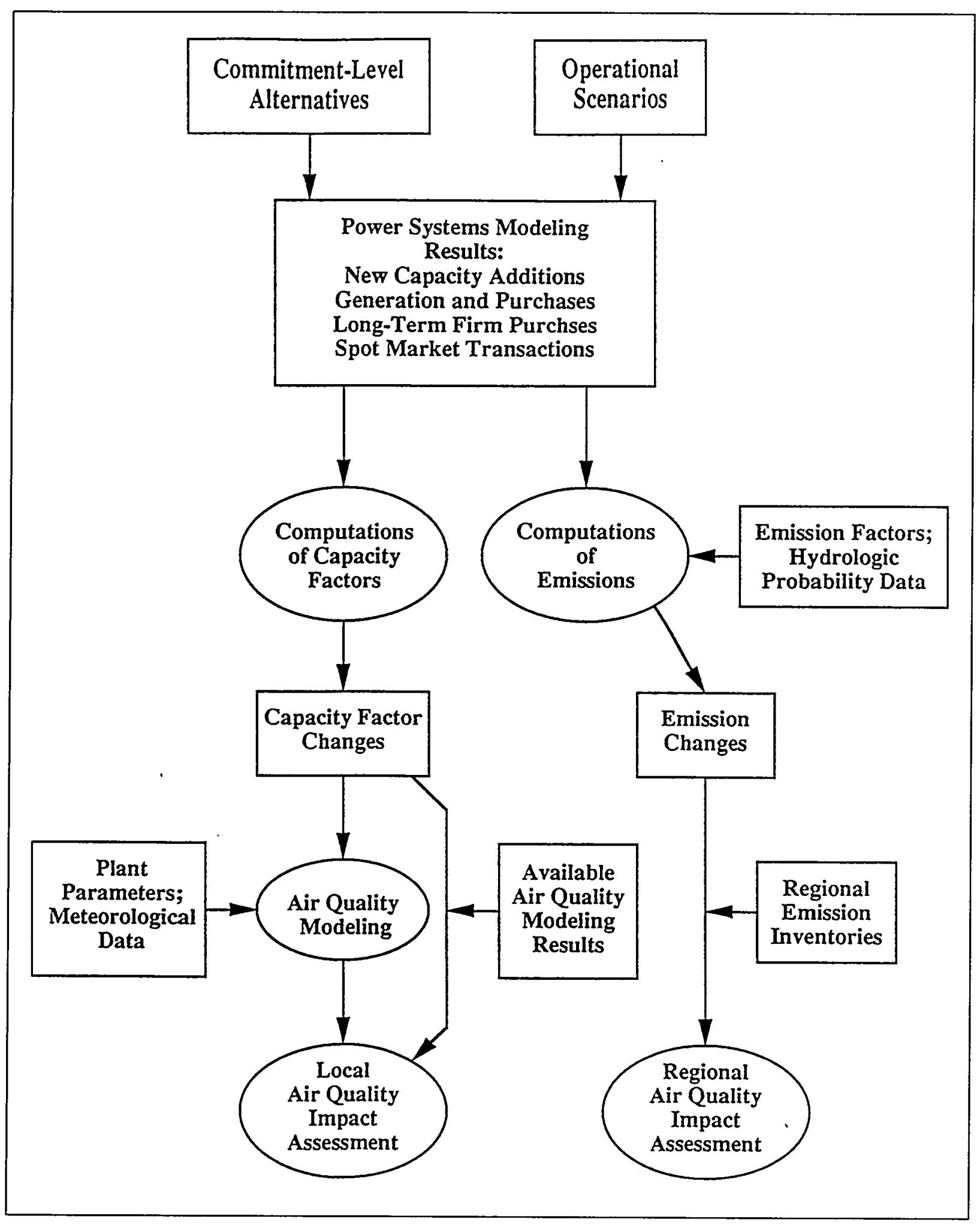

FIGURE 5 Components of Air Quality Impact Assessment 
TABLE 11 New Generation Capacities of the Region's 17 Utility Systems Projected for 1998 and 2008 under Selected Commitment-Level Alternatives and Operational Scenarios

\begin{tabular}{|c|c|c|c|c|c|}
\hline \multirow{2}{*}{\multicolumn{2}{|c|}{ Generating Unit }} & \multicolumn{4}{|c|}{ New Generation Capacities (MW) under Various Alternatives, ${ }^{a} 1998$} \\
\hline & & \multirow[b]{2}{*}{ No Action } & \multirow[b]{2}{*}{$\begin{array}{l}\text { High Capacity, } \\
\text { Low Energy }\end{array}$} & \multirow[b]{2}{*}{$\begin{array}{l}\text { Low Capacity, } \\
\text { Low Energy }\end{array}$} & \multirow[b]{2}{*}{$\begin{array}{l}\text { Low Capacity, } \\
\text { High Energy }\end{array}$} \\
\hline Type & Size & & & & \\
\hline \multirow[t]{4}{*}{ Diesel } & 1.6 & 0 & 0 & 0 & 0 \\
\hline & 2.4 & 2.2 & 0 & 0 & 0 \\
\hline & 3.2 & 0 & 0 & 0 & 0 \\
\hline & 12 & $\mathbf{0}$ & 0 & 22 & 0 \\
\hline \multicolumn{2}{|l|}{ Subtotal } & 2.2 & 0 & 22 & 0 \\
\hline \multirow{8}{*}{ Gas turbine } & 8.8 & 0 & 7.7 & 7.7 & 23.1 \\
\hline & 20 & 0 & 0 & 16.7 & 0 \\
\hline & 31 & 0 & 0 & 51.8 & 51.8 \\
\hline & 40 & 564.8 & 564.8 & 564.8 & 598.2 \\
\hline & 75 & 0 & 0 & 65 & 0 \\
\hline & 80 & $1,812.6(\mathrm{~A})$ & $1,812.6(\mathrm{~A})$ & $2,242.0(\mathrm{~A})$ & $2,096.0(\mathrm{~A})$ \\
\hline & & $1,958.8$ (B) & $1,812.6(\mathrm{~B})$ & $2,242.0$ (B) & $1,877.0(\mathrm{~B})$ \\
\hline & & $1,958.6(\mathrm{C})$ & $1,812.6(\mathrm{C})$ & $2,242.0(\mathrm{C})$ & $2,023.0(\mathrm{C})$ \\
\hline \multirow[t]{3}{*}{ Subtotal } & & $2,377.4(\mathrm{~A})$ & $2,385.1(\mathrm{~A})$ & $2,948.0(\mathrm{~A})$ & $2,769.1(\mathrm{~A})$ \\
\hline & & $2,523.4$ (B) & $2,385.1(\mathrm{~B})$ & $2,948.0(\mathrm{~B})$ & $2,550.1(\mathrm{~B})$ \\
\hline & & $2,523.4(\mathrm{C})$ & $2,385.1(\mathrm{C})$ & $2,948.0(\mathrm{C})$ & $2,696.1(\mathrm{C})$ \\
\hline \multirow[t]{5}{*}{ Combined cycle } & 15.9 & 0 & 13.7 & 13.7 & 13.7 \\
\hline & 50 & 0 & 0 & 0 & 0 \\
\hline & 200 & $0(\mathrm{~A})$ & $186.0(\mathrm{~A})$ & $0(\mathrm{~A})$ & $0(A)$ \\
\hline & & 0 (B) & 186.0 (B) & 0 (B) & $186.0(\mathrm{~B})$ \\
\hline & & $0(\mathrm{C})$ & $186.0(\mathrm{C})$ & $0(\mathrm{C})$ & $0(\mathrm{C})$ \\
\hline \multirow[t]{3}{*}{ Subtotal } & & $0(A)$ & $199.7(\mathrm{~A})$ & $13.7(\mathrm{~A})$ & $13.7(\mathrm{~A})$ \\
\hline & & 0 (B) & $199.7(\mathrm{~B})$ & 13.7 (B) & $199.7(\mathrm{~B})$ \\
\hline & & $0(\mathrm{C})$ & $199.7(\mathrm{C})$ & $13.7(\mathrm{C})$ & $13.7(\mathrm{C})$ \\
\hline IGCC ${ }^{b}$ & 400 & 0 & 0 & 0 & 0 \\
\hline$A F B C^{c}$ & 200 & 400 & 400 & 400 & 400 \\
\hline \multirow{3}{*}{$\begin{array}{l}\text { Pulverized } \\
\text { Coal-fired } \\
\text { Boiler }\end{array}$} & 150 & 150 & 150 & 150 & 150 \\
\hline & 200 & 0 & 0 & 0 & 0 \\
\hline & 300 & 300 & 300 & 300 & 300 \\
\hline \multicolumn{2}{|l|}{ Subtotal } & 450 & 450 & 450 & 450 \\
\hline \multirow[t]{3}{*}{ Total } & & $3,229.6(\mathrm{~A})$ & $3,434.8(\mathrm{~A})$ & $3,833.7$ (A) & $3,632.8(\mathrm{~A})$ \\
\hline & & $3,375.6(\mathrm{~B})$ & $3,434.8(\mathrm{~B})$ & $3,833.7$ (B) & $3,599.8$ (B) \\
\hline & & $3,375.6(\mathrm{C})$ & $3,434.8(\mathrm{C})$ & $3,833.7(\mathrm{C})$ & $3,559.8$ (C) \\
\hline
\end{tabular}




\section{TABLE 11 (Cont.)}

\begin{tabular}{|c|c|c|c|c|c|}
\hline \multirow{2}{*}{\multicolumn{2}{|c|}{ Generating Unit }} & \multicolumn{4}{|c|}{ New Generation Capacities (MW) under Various Alternatives, ${ }^{\text {a }} 2008$} \\
\hline & & \multirow[b]{2}{*}{ No Action } & \multirow[b]{2}{*}{$\begin{array}{c}\text { High Capacity, } \\
\text { Low Energy }\end{array}$} & \multirow[b]{2}{*}{$\begin{array}{l}\text { Low Capacity, } \\
\text { Low Energy }\end{array}$} & \multirow[b]{2}{*}{$\begin{array}{l}\text { Low Capacity, } \\
\text { High Energy }\end{array}$} \\
\hline Type & Size & & & & \\
\hline \multirow[t]{4}{*}{ Diesel } & -1.6 & 0 & 0 & 0 & 1.5 \\
\hline & 2.4 & 2.2 & 0 & 0 & 0 \\
\hline & 3.2 & 2.9 & 0 & 2.9 & 0 \\
\hline & 12 & 0 & 0 & 22 & 0 \\
\hline \multicolumn{2}{|l|}{ Subtotal } & 5.1 & o & 24.9 & 1.5 \\
\hline \multirow[t]{8}{*}{ Gas turbine } & 8.8 & 7.3 & 7.7 & 23.1 & 38.5 \\
\hline & 20 & 34 & 16.7 & 67.4 & 67.4 \\
\hline & 31 & 26.8 & 0 & 51.8 & 51.8 \\
\hline & 40 & 794.8 & 864.6 & 864.6 & 898 \\
\hline & 75 & 0 & 65 & 130 & 130 \\
\hline & 80 & $3,618.5$ (A) & $3,403.4$ (A) & $4,047.9$ (A) & $4,047.9$ (A) \\
\hline & & $3,910.5$ (B) & $3,403.4$ (B) & $4,047.9(\mathrm{~B})$ & $3,609.9$ (B) \\
\hline & & $3,910.5$ (C) & $3,403.4$ (C) & $4,120.9$ (C) & $3,755.9$ (C) \\
\hline \multirow[t]{3}{*}{ Subtotal } & & $4,481.4$ (A) & $4,357.4(\mathrm{~A})$ & $5,184.8(A)$ & $5,233.6$ (A) \\
\hline & & $4,773.4$ (B) & $4,357.4$ (B) & $5,184.8$ (B) & $4,795.6$ (B) \\
\hline & & $4,773.4(C)$ & $4,357.4(\mathrm{C})$ & $5,257.8(\mathrm{C})$ & $4,941.6(\mathrm{C})$ \\
\hline \multirow[t]{5}{*}{ Combined cycle } & 15.9 & 27.4 & 54.3 & 67.5 & 41.1 \\
\hline & 50 & 44 & 0 & 0 & 0 \\
\hline & 200 & $0(A)$ & $186.0(\mathrm{~A})$ & $0(A)$ & $0(\mathrm{~A})$ \\
\hline & & 0 (B) & 186.0 (B) & 0 (B) & 186.0 (B) \\
\hline & & $0(\mathrm{C})$ & $186.0(\mathrm{C})$ & $0(\mathrm{C})$ & $0(\mathrm{C})$ \\
\hline \multirow[t]{3}{*}{ Subtotal } & & 71.4 (A) & $240.3(\mathrm{~A})$ & $67.5(\mathrm{~A})$ & 41.1 (A) \\
\hline & & 71.4 (B) & 240.3 (B) & 67.5 (B) & 227.1 (B) \\
\hline & & 71.4 (C) & 240.3 (C) & 67.5 (C) & $41.1(\mathrm{C})$ \\
\hline IGCC ${ }^{b}$ & 400 & 800 & 800 & 800 & 800 \\
\hline $\mathrm{AFBC}^{\mathrm{c}}$ & 200 & 800 & 800 & 800 & 800 \\
\hline Pulverized & 150 & 300 & 300 & 300 & 300 \\
\hline Coal-fired & 200 & 400 & 400 & 400 & 400 \\
\hline Boiler & 300 & 4,200 & 4,200 & 4,200 & 4,200 \\
\hline \multicolumn{2}{|l|}{ Subtotal } & 4,900 & 4,900 & 4,900 & 4,900 \\
\hline \multirow{3}{*}{\multicolumn{2}{|c|}{ Total }} & $11,057.9(\mathrm{~A})$ & $11,097.7(\mathrm{~A})$ & $11,777.2(\mathrm{~A})$ & $11,776.2(\mathrm{~A})$ \\
\hline & & $11,349.9$ (B) & $11,097.7$ (B) & $11,777.2$ (B) & $11,524.2$ (B) \\
\hline & & $11,349.9$ (C) & $11,097.7$ (C) & $11,850.2$ (C) & $11,484.2$ (C) \\
\hline
\end{tabular}

a Letters in parentheses represent supply options A, B, and C, respectively.

b Integrated gasification and combined cycle.

c Atmospheric fluidized bed combustion. 
TABLE 12 Air Pollutant Emission Factors Weighted for Projected Electric Energy Generation by the Region's 17 Electric Utility Systems

\begin{tabular}{|c|c|c|c|c|c|c|c|c|}
\hline \multirow{2}{*}{$\begin{array}{c}\text { Unit Type/ } \\
\text { Commitment-Level } \\
\text { Alternative }\end{array}$} & \multirow[b]{2}{*}{ Year } & \multirow{2}{*}{$\begin{array}{c}\text { Annual } \\
\text { Generation } \\
\text { (GWh) }\end{array}$} & \multicolumn{6}{|c|}{ Weighted Emission Factor (ton/GWh) ${ }^{\mathbf{a}}$} \\
\hline & & & $\mathrm{SO}_{2}$ & $\mathrm{NO}_{x}$ & $\mathrm{CO}$ & VOC & TSP & $\mathrm{CO}_{2}$ \\
\hline \multicolumn{9}{|l|}{ Peaking } \\
\hline \multirow[t]{3}{*}{ No Action } & 1993 & 2,029 & 0.1707 & 2.853 & 0.4836 & 0.1000 & 0.0796 & 230.5 \\
\hline & 1998 & 6,660 & 0.1223 & 1.656 & 0.3004 & 0.0331 & 0.0828 & 226.6 \\
\hline & 2008 & 8,578 & 0.1248 & 1.578 & 0.2854 & 0.0268 & 0.0849 & 224.7 \\
\hline \multirow[t]{3}{*}{ High Capacity, Low Energy } & 1993 & 2,240 & 0.2045 & 3.667 & 0.6198 & 0.1199 & 0.1156 & 228.9 \\
\hline & 1998 & 6,744 & 0.1344 & 1.907 & 0.3426 & 0.0401 & 0.0930 & 226.6 \\
\hline & 2008 & 8,891 & 0.1398 & 1.896 & 0.3397 & 0.0360 & 0.0982 & 224.5 \\
\hline \multicolumn{9}{|l|}{ Low Capacity, Low Energy } \\
\hline & 1993 & 2,160 & 0.1798 & 3.137 & 0.5263 & 0.1061 & 0.0904 & 229.4 \\
\hline & 1998 & 7,272 & 0.1528 & 1.947 & 0.3485 & 0.0405 & 0.0968 & 225.4 \\
\hline & 2008 & 9,553 & 0.1676 & 2.147 & 0.3853 & 0.0427 & 0.1123 & 224.2 \\
\hline \multirow{4}{*}{ Low Capacity, High Energy } & & & & & & & 0.0743 & 230.6 \\
\hline & 1993 & 2,034 & 0.1655 & 2.745 & 0.4623 & 0.0963 & & \\
\hline & 1998 & 6,768 & 0.1241 & 1.708 & 0.3064 & 0.0342 & 0.0843 & 226.6 \\
\hline & 2008 & 8,867 & 0.1233 & 1.567 & 0.2812 & 0.0264 & 0.0840 & 224.3 \\
\hline \multicolumn{9}{|l|}{ Intermediate and Baseload } \\
\hline \multirow[t]{3}{*}{ No Action } & 1993 & 121,497 & 2.879 & 3.115 & 0.1581 & 0.0205 & 1.344 & 266.7 \\
\hline & 1998 & 131,102 & 2.707 & 3.024 & 0.1630 & 0.0218 & 1.203 & 264.3 \\
\hline & 2008 & 167,763 & 2.369 & $2.977^{\circ}$ & 0.1577 & 0.0197 & 0.921 & 267.4 \\
\hline \multirow[t]{3}{*}{ High Capacity, Low Energy } & 1993 & 122,784 & 2.852 & 3.107 & 0.1585 & 0.0206 & 1.331 & 266.9 \\
\hline & 1998 & 132,688 & 2.670 & 3.008 & 0.1631 & 0.0217 & 1.189 & 264.1 \\
\hline & 2008 & 169,109 & 2.345 & 2.966 & 0.1578 & 0.0196 & 0.914 & 267.0 \\
\hline \multicolumn{9}{|l|}{ Low Capacity, Low Energy } \\
\hline & 1993 & 122,705 & 2.858 & 3.113 & 0.1583 & 0.0206 & 1.332 & 266.9 \\
\hline & 1998 & 132,481 & 2.686 & 3.020 & 0.1631 & 0.0218 & 1.192 & 264.4 \\
\hline & 2008 & 168,875 & 2.356 & 2.975 & 0.1578 & 0.0197 & 0.916 & 267.3 \\
\hline \multicolumn{9}{|l|}{ Low Capacity, High Energy } \\
\hline & 1993 & 121,699 & 2.883 & 3.119 & 0.1580 & 0.0205 & 1.343 & 267.0 \\
\hline & 1998 & 131,587 & 2.702 & 3.019 & 0.1627 & 0.0216 & 1.199 & 264.3 \\
\hline & 2008 & 167,779 & 2.371 & 2.977 & 0.1576 & 0.0195 & 0.921 & 267.5 \\
\hline
\end{tabular}

a For the case of supply option B. Weighted emission factors for supply options A and C are identical to those for supply option B for all practical purposes.

individual utilities were estimated in two different ways: (1) if the identity of the purchase source was known, the emissions were estimated by multiplying the amount of projected electric energy purchase with the average emission factors weighted for all generating units owned by the utility from which the electric energy would be purchased; or (2) if the identity of the purchase source was not known, the emissions were estimated by multiplying the amount of projected electric energy purchase with the average emission factors weighted for all generating units owned by all of the region's utility systems. For use in subsequent air quality impact analyses, changes in electric energy generation, capacity factors, and air pollutant emissions of existing individual generating units relative to the no-action alternative case were then calculated for the three remaining commitment-level alternatives paired with the three supply options. 
TABLE 13 Air Pollutant Emission Factors Assigned to Projected New Generating Units

\begin{tabular}{|c|c|c|c|c|c|c|c|c|}
\hline \multirow[b]{2}{*}{ Fuel } & \multirow[b]{2}{*}{ State $^{a}$} & \multirow{2}{*}{$\begin{array}{c}\text { Utility } \\
\text { Pool No. }\end{array}$} & \multicolumn{6}{|c|}{ Emission Factor (lb/10 $\left.0^{6} \mathrm{Btu}\right)$} \\
\hline & & & $\mathrm{SO}_{2}$ & $\mathrm{NO}_{\mathrm{x}}$ & $\mathrm{CO}$ & VOC & TSP & $\mathrm{CO}_{2}$ \\
\hline \multirow[t]{6}{*}{$\mathrm{Coal}^{\mathrm{c}}$} & Arizona & $51,52,53,55$ & 0.25 & 0.6 & $0.03^{\mathrm{d}}$ & $0.003^{\mathrm{d}}$ & 0.03 & 56 \\
\hline & Colorado & $54,56,57,58,59$ & 0.20 & 0.5 & $0.03^{\mathrm{d}}$ & $0.003^{d}$ & 0.03 & 57 \\
\hline & Nevada & 60 & 0.23 & 0.6 & $0.03^{d}$ & $0.003^{d}$ & 0.03 & 56 \\
\hline & New Mexico & 63,64 & 0.45 & 0.5 & $0.03^{\mathrm{d}}$ & $0.003^{\mathrm{d}}$ & 0.03 & 57 \\
\hline & Utah & $61,62,65,66$ & 0.23 & 0.6 & $0.03^{d}$ & $0.003^{d}$ & 0.03 & 56 \\
\hline & Wyoming & 67 & 0.19 & 0.5 & $0.03^{d}$ & $0.003^{d}$ & 0.03 & 57 \\
\hline Residual oil & - & - & $1.0^{\mathrm{d}}$ & $3.5^{\mathrm{d}}$ & $0.65^{\mathrm{d}}$ & $0.1^{d}$ & $0.2^{\mathrm{d}}$ & 49 \\
\hline Distillate oil & - & - & $0.2^{\mathrm{d}}$ & $3.5^{\mathrm{d}}$ & $0.65^{\mathrm{d}}$ & $0.1^{\mathrm{d}}$ & $0.2^{\mathrm{d}}$ & 45 \\
\hline Natural gas & - & - & $0.02^{\mathrm{d}}$ & $0.45^{\mathrm{d}, \mathrm{e}}$ & $0.04^{\mathrm{d}}$ & $0.003^{\mathrm{d}}$ & $0.015^{\mathrm{d}}$ & 35 \\
\hline
\end{tabular}

a A hyphen indicates that no distinction was made with respect to state or utility system.

b As carbon.

c New Source Performance Standards for bituminous or subbituminous coal were selected for plants to be located in individual states depending on the average heating value of the coal used by electric utilities in each state.

d Median values for existing units.

- $0.2 \mathrm{lb} / 10^{6} \mathrm{Btu}$ for units of more than $250 \times 10^{6} \mathrm{Btu} / \mathrm{h}$ heat input rate $(73 \mathrm{MW})$.

Modeling for the local air quality assessment was conducted for selected new generating units with the Industrial Source Complex (ISC) model recommended by the EPA (1986), typical plant parameters, meteorological data for selected locations within the sixstate study region, and certain simplifying assumptions (Tables A.1 through A.4 in the appendix). Subsequent assessments were made on the basis of the significance of predicted ambient air quality impacts in the vicinity of new generating units and the significance of capacity factor changes at existing individual generating units, under the selected commitment-level alternative and supply option combinations.

The following additional analyses were performed for assessing potential impacts on regional air quality and greenhouse gas emissions: (1) computation of emissions associated with changes in electricity generation by the region's utilities to compensate for the changes in Western's hydroelectric generation from long-term and short-term firm sales commitments and to cover Western's long-term firm purchases and (2) a subsequent comparison of the differences in net totals of those emissions among the four commitment-level alternatives analyzed for this report. 


\section{POTENTIAL ENVIRONMENTAL CONSEQUENCES}

\subsection{AIR QUALITY}

\subsubsection{Commitment-Level Alternatives}

The proposed commitment-level alternatives and supply options were assessed for potential impacts on local and regional air quality and on regional emissions of greenhouse gases. The assessments presented here are based on the results of (1) a series of analyses to estimate potential changes in capacity factors and air pollutant emissions for individual generating units owned by the region's utility systems affected by Western's commitmentlevel alternatives, (2) a review of air quality impact modeling results available from federal and state agencies for the existing generating units, and (3) air quality modeling performed to estimate potential ambient air quality impacts of operating projected new generating units. The methodology used to perform these analyses is described in Section 3.

\subsubsection{Local Air Quality}

Potential impacts of Western's commitment-level alternatives on local air quality were assessed for existing generating plants as well as for projected new units. The generating capacity of each plant or unit, its projected annual generation of electric energy and capacity factor under the no-action alternative, and changes in annual generation and capacity factor under other commitment-level alternatives relative to the no-action alternative are listed in Table 14 for existing peaking plants and in Table 15 for intermediate and baseload plants. Corresponding data for projected new units are given in Tables 16 and 17, respectively.

The existing peaking plants with units having more than a $10 \%$ change in the annual capacity factor relative to the no-action alternative during any one of the three years evaluated (1993, 1998, and 2008) are all small plants in relatively small cities that have an individual total plant generating capacity of $19 \mathrm{MW}$ or less (Table 14). The percent changes in annual capacity factor from the no-action alternative range from 0 to $-7 \%$ for the low-capacity, high-energy alternative in 1993 to 30 to $73 \%$ for the low-capacity, low energy alternative in 2008. However, none of these plants have annual capacity factors greater than $85 \%$ in any of the three years considered. Because air quality impacts of these small peaking plants are small, even at a $100 \%$ annual capacity factor, potential impacts on ambient air quality of the projected changes in annual capacity factors at these plants are expected to be minor. (See the appendix, Tables A.1 and A.2, for the estimated ambient air quality impacts for similar plants.)

The existing intermediate and baseload plants with units having more than a $10 \%$ change in annual capacity factor from the no-action alternative during any one of the three 
TABLE 14 Changes in Annual Generation and Capacity Factor of Existing Peaking Units under Selected Commitment-Level Alternatives in 1993, 1998, and $2008^{\mathrm{a}}$

\begin{tabular}{|c|c|c|c|c|c|c|c|c|c|c|}
\hline \multirow[b]{2}{*}{ Year } & \multirow[b]{2}{*}{$\begin{array}{l}\text { Plant and Unit } \\
\text { Identification }\end{array}$} & \multirow[b]{2}{*}{$\begin{array}{l}\text { Capacity } \\
\text { (MW) }\end{array}$} & \multicolumn{2}{|c|}{ No Action } & \multicolumn{2}{|c|}{$\begin{array}{l}\text { High Capacity, } \\
\text { Low Energy }\end{array}$} & \multicolumn{2}{|c|}{$\begin{array}{l}\text { Low Capacity, } \\
\text { Low Energy }\end{array}$} & \multicolumn{2}{|c|}{$\begin{array}{l}\text { Low Capacity, } \\
\text { High Energy }\end{array}$} \\
\hline & & & $\begin{array}{c}\text { Annual } \\
\text { Generation } \\
\text { (GWh) }\end{array}$ & $\begin{array}{c}\text { Capacity } \\
\text { Factor } \\
(\%)\end{array}$ & $\begin{array}{c}\Delta \text { Annual } \\
\text { Generation } \\
(G W h)\end{array}$ & $\begin{array}{c}\Delta \text { Capacity } \\
\text { Factor } \\
\cdot(\%)\end{array}$ & $\begin{array}{c}\Delta \text { Annual } \\
\text { Generation } \\
\text { (GWh) }\end{array}$ & $\begin{array}{c}\Delta \text { Capacity } \\
\text { Factor } \\
(\%)\end{array}$ & $\begin{array}{c}\Delta \text { Annual } \\
\text { Generation } \\
\text { (GWh) }\end{array}$ & $\begin{array}{c}\Delta \text { Capacity } \\
\text { Factor } \\
(\%)\end{array}$ \\
\hline \multirow[t]{9}{*}{1993} & Facility A & 19.0 & 1.7 & 1.0 & 25.8 & 15.5 & 30.4 & 18.3 & 12.9 & 7.7 \\
\hline & Facility B & 15.1 & 17.7 & 13.4 & 44.1 & 33.3 & 16.4 & 12.4 & -4.7 & -3.6 \\
\hline & Facility C & 0.6 & 0.2 & 3.0 & 0.3 & 6.5 & 0.1 & 1.1 & -0.1 & -1.0 \\
\hline & Facility D & 4.8 & 2.2 & 5.3 & 5.0 & 11.9 & 0.7 & 1.8 & -0.7 & -1.6 \\
\hline & Facility $E$ & 7.2 & 1.6 & 2.6 & 5.6 & 8.8 & 1.0 & 1.6 & -0.3 & -0.4 \\
\hline & Facility F & 6.6 & 0.7 & 1.2 & 3.2 & 5.5 & 0.8 & 1.4 & -0.0 & 0.0 \\
\hline & Facility G & 5.4 & 7.8 & 16.5 & 19.5 & 41.3 & 6.7 & 14.1 & .2 .4 & -5.1 \\
\hline & Facility $\mathrm{H}$ & 14.0 & 26.8 & 21.9 & 49.9 & 40.7 & 17.4 & 14.2 & -8.2 & -6.7 \\
\hline & Facility I & 14.0 & 8.7 & 7.1 & 19.6 & 15.9 & 7.4 & 6.0 & -1.9 & -1.6 \\
\hline \multirow[t]{9}{*}{1998} & Facility A & 19.0 & 7.2 & 4.3 & 15.2 & 9.1 & .3 .0 & -1.8 & 1.2 & 0.7 \\
\hline & Facility B & 15.1 & 12.2 & 9.2 & 27.9 & 21.1 & 32.3 & 24.4 & 3.8 & 2.9 \\
\hline & Facility C & 0.6 & 0.1 & 1.4 & 0.4 & 7.0 & 0.4 & 7.6 & 0.1 & 1.5 \\
\hline & Facility D & 4.8 & 1.1 & 2.6 & 5.1 & 12.2 & 5.8 & 13.9 & 1.0 & 2.4 \\
\hline & Facility E & 7.2 & 1.0 & 1.6 & 4.7 & 7.4 & 5.3 & 8.5 & 0.9 & 1.4 \\
\hline & Facility F & 6.6 & 0.5 & 0.9 & 2.5 & 4.3 & 2.9 & 5.0 & 0.5 & 0.9 \\
\hline & Facility G & 5.4 & 5.5 & 11.6 & 10.1 & 21.4 & 12.2 & 25.8 & 1.0 & 2.0 \\
\hline & Facility H & 14.0 & 16.9 & 13.8 & 42.6 & 34.8 & 40.2 & 32.8 & 6.7 & 5.4 \\
\hline & Facility I & 14.0 & 5.2 & 4.3 & 21.1 & 17.2 & 23.5 & 19.1 & 3.9 & 3.2 \\
\hline \multirow[t]{9}{*}{2008} & Facility A & 19.0 & 8.2 & 4.9 & 10.5 & 6.3 & .4 .7 & -2.8 & -0.5 & .0 .3 \\
\hline & Facility B & 15.1 & 13.1 & 9.9 & 51.4 & 38.8 & 87.5 & 66.2 & .2 .7 & -2.1 \\
\hline & Facility C & 0.6 & 0.1 & 2.0 & 0.7 & 12.9 & 1.9 & 36.5 & 0.0 & 0.4 \\
\hline & Facility D & 4.8 & 1.5 & 3.5 & 9.8 & 23.2 & 27.7 & 65.8 & 0.3 & 0.6 \\
\hline & Facility E & 7.2 & 1.3 & 2.1 & 10.3 & 16.4 & 29.1 & 46.2 & 0.4 & 0.6 \\
\hline & Facility $F$ & 6.6 & 0.7 & 1.2 & 6.4 & 11.1 & 17.5 & 30.3 & 0.3 & 0.5 \\
\hline & Facility G & 5.4 & 5.4 & 11.4 & 19.9 & 42.0 & 34.5 & 72.8 & -1.2 & -2.6 \\
\hline & Facility $\mathrm{H}$ & 14.0 & 22.4 & 18.3 & 60.9 & 49.7 & 67.8 & 55.3 & -9.4 & -7.6 \\
\hline & Facility I & 14.0 & 6.5 & 5.3 & 36.2 & 29.5 & 88.2 & 71.9 & 0.3 & 0.2 \\
\hline
\end{tabular}

a Listed are only the existing plants with one or more generating units having more than a $10 \%$ capacity factor change from the no-action alternative case in any one of the selected three years.

b The number of peaking units included in Facilities $A$ through I ranges from 2 to 6. 
TABLE 15 Changes in Annual Generation and Capacity Factor of Existing Intermediate and Baseload Units under Selected Commitment-Level Alternatives in 1993, 1998, and $2008^{\mathrm{a}}$

\begin{tabular}{|c|c|c|c|c|c|c|c|c|c|c|}
\hline \multirow[b]{2}{*}{ Year } & \multirow[b]{2}{*}{$\begin{array}{l}\text { Plant and Unit } \\
\text { Identification }\end{array}$} & \multirow[b]{2}{*}{$\begin{array}{l}\text { Capacityc }^{c} \\
\text { (MW) }\end{array}$} & \multicolumn{2}{|c|}{ No Action } & \multicolumn{2}{|c|}{$\begin{array}{l}\text { High Capacity, } \\
\text { Low Energy }\end{array}$} & \multicolumn{2}{|c|}{$\begin{array}{l}\text { Low Capacity, } \\
\text { Low Energy }\end{array}$} & \multicolumn{2}{|c|}{$\begin{array}{l}\text { Low Capacity, } \\
\text { High Energy }\end{array}$} \\
\hline & & & $\begin{array}{l}\text { Annual } \\
\text { Generation } \\
\text { (GWh) }\end{array}$ & $\begin{array}{c}\text { Capacity } \\
\text { Factor } \\
(\%)\end{array}$ & $\begin{array}{c}\Delta \text { Annual } \\
\text { Generation } \\
(G W h)\end{array}$ & $\begin{array}{c}\Delta \text { Capacity } \\
\text { Factor }^{d} \\
\text { (\%) }\end{array}$ & $\begin{array}{c}\Delta \text { Annual } \\
\text { Generation } \\
(G W h)\end{array}$ & $\begin{array}{c}\Delta \text { Capacity } \\
\text { Factord }^{d} \\
(\%)\end{array}$ & $\begin{array}{c}\triangle \text { Annual } \\
\text { Generation } \\
(G W h)\end{array}$ & $\begin{array}{c}\Delta \text { Capacity }^{\Delta \text { Factor }^{\mathrm{d}}} \\
(\%)\end{array}$ \\
\hline \multirow[t]{8}{*}{1993} & Facility $\mathbf{J}$ & $\begin{array}{r}148.0 \\
(2,268)\end{array}$ & 995.4 & 76.8 & -387.6 & $\begin{array}{l}-29.9 \\
(-2.0)\end{array}$ & -241.3 & $\begin{array}{l}-18.6 \\
(-1.2)\end{array}$ & .64 .8 & $\begin{array}{l}-5.0 \\
(-0.3)\end{array}$ \\
\hline & Facility K & $1,263.6$ & $6,915.2$ & 62.5 & -8.9 & -0.1 & 5.5 & 0.0 & 83.2 & 0.8 \\
\hline & Facility L & .446 .2 & $1,878.9$ & 48.1 & .193 .7 & -5.0 & .89 .1 & -2.3 & .73 .7 & -1.9 \\
\hline & Facility $M$ & $\begin{array}{r}420.6 \\
(1,650)\end{array}$ & $2,845.6$ & 77.2 & 178.5 & $\begin{array}{c}4.8 \\
(1.2)\end{array}$ & 268.2 & $\begin{array}{c}7.3 \\
(1.9)\end{array}$ & .87 .6 & $\begin{array}{l}-2.4 \\
(-0.6)\end{array}$ \\
\hline & Facility $N$ & 235.0 & $1,377.3$ & 66.9 & 219.7 & 10.7 & 201.5 & 9.8 & 10.4 & .0 .5 \\
\hline & Facility $O$ & $\begin{array}{r}42.0 \\
(1,572)\end{array}$ & 245.0 & 66.6 & 17.8 & $\begin{array}{c}4.8 \\
(0.1)\end{array}$ & 13.9 & $\begin{array}{c}3.8 \\
(0.1)\end{array}$ & -4.8 & $\begin{array}{l}-1.3 \\
(0.0)\end{array}$ \\
\hline & Facility $P$ & $\begin{array}{c}31.0 \\
(400)\end{array}$ & 30.6 & 11.3 & 130.6 & $\begin{array}{l}48.1 \\
(3.7)\end{array}$ & 128.4 & $\begin{array}{l}47.3 \\
(3.7)\end{array}$ & 52.6 & $\begin{array}{l}19.4 \\
(1.5)\end{array}$ \\
\hline & Facility $\mathbf{Q}$ & $\begin{array}{r}81.9 \\
(1,338)\end{array}$ & 493.1 & 68.7 & 135.5 & $\begin{array}{l}18.9 \\
(1.2)\end{array}$ & 81.3 & $\begin{array}{l}11.3 \\
(0.7)\end{array}$ & .32 .1 & $\begin{array}{c}-4.5 \\
(-0.3)\end{array}$ \\
\hline \multirow[t]{8}{*}{1998} & Facility $J$ & $\begin{array}{r}148.0 \\
(2,268)\end{array}$ & 933.8 & 72.0 & .399 .3 & $\begin{array}{l}-30.8 \\
(-2.0)\end{array}$ & -248.4 & $\begin{array}{l}-19.2 \\
(-1.3)\end{array}$ & -61.1 & $\begin{array}{c}-4.7 \\
(-0.3)\end{array}$ \\
\hline & Facility $\mathrm{K}$ & $1,263.6$ & $6,720.7$ & 60.7 & 42.3 & 0.4 & 365.6 & 3.3 & 109.3 & 1.0 \\
\hline & Facility L & 446.2 & $2,110.2$ & 54.0 & -70.4 & -1.8 & 25.5 & 0.7 & 31.3 & 0.8 \\
\hline & Facility M & $\begin{array}{r}420.6 \\
(1,650)\end{array}$ & $2,583.5$ & 70.1 & 438.7 & $\begin{array}{l}11.9 \\
(3.0)\end{array}$ & 259.4 & $\begin{array}{c}7.0 \\
(1.8)\end{array}$ & 194.1 & $\begin{array}{c}5.3 \\
(1.3)\end{array}$ \\
\hline & Facility $N$ & 235.0 & $1,460.8$ & 71.0 & 233.6 & 11.3 & 212.1 & 10.3 & 3.3 & 0.2 \\
\hline & Facility $O$ & $\begin{array}{r}42.0 \\
(1,572)\end{array}$ & 263.3 & 71.6 & 7.8 & $\begin{array}{c}2.1 \\
(0.1)\end{array}$ & 7.3 & $\begin{array}{c}2.0 \\
(0.1)\end{array}$ & -1.5 & $\begin{array}{l}-0.4 \\
(0.0)\end{array}$ \\
\hline & Facility $P$ & $\begin{array}{r}31.0 \\
(400)\end{array}$ & 87.0 & 32.0 & 52.8 & $\begin{array}{l}19.5 \\
(1.5)\end{array}$ & 54.8 & $\begin{array}{l}20.2 \\
(1.6)\end{array}$ & .11 .2 & $\begin{array}{c}-4.1 \\
(-0.3)\end{array}$ \\
\hline & Facility $Q$ & $\begin{array}{r}81.9 \\
(1,338)\end{array}$ & 534.5 & 74.5 & 55.6 & $\begin{array}{c}7.7 \\
(0.5)\end{array}$ & 56.8 & $\begin{array}{c}7.9 \\
(0.5)\end{array}$ & .23 .8 & $\begin{array}{c}-3.3 \\
(-0.2)\end{array}$ \\
\hline
\end{tabular}


TABLE 15 (Cont.)

\begin{tabular}{|c|c|c|c|c|c|c|c|c|c|c|}
\hline \multirow[b]{2}{*}{ Year } & \multirow[b]{2}{*}{$\begin{array}{l}\text { Plant and Unit } \\
\text { Identification }\end{array}$} & \multirow[b]{2}{*}{$\begin{array}{l}\text { Capacitye } \\
(\mathrm{MW})\end{array}$} & \multicolumn{2}{|c|}{ No Action } & \multicolumn{2}{|c|}{$\begin{array}{l}\text { High Capacity, } \\
\text { Low Energy }\end{array}$} & \multicolumn{2}{|c|}{$\begin{array}{l}\text { Low Capacity, } \\
\text { Low Energy }\end{array}$} & \multicolumn{2}{|c|}{$\begin{array}{l}\text { Low Capacity, } \\
\text { High Energy }\end{array}$} \\
\hline & & & $\begin{array}{l}\text { Annual } \\
\text { Generation } \\
\text { (GWh) }\end{array}$ & $\begin{array}{l}\text { Capacity } \\
\text { Factor } \\
(\%)\end{array}$ & $\begin{array}{c}\Delta \text { Annual } \\
\text { Generation } \\
\text { (GWh) }\end{array}$ & $\begin{array}{l}\Delta \text { Capacity } \\
\text { Factor }^{d} \\
(\%)\end{array}$ & $\begin{array}{l}\Delta \text { Annual } \\
\text { Generation } \\
(G W h)\end{array}$ & $\begin{array}{c}\Delta \text { Capacity } \\
\text { Factor }^{d} \\
(\%)\end{array}$ & $\begin{array}{c}\Delta \text { Annual } \\
\text { Generation } \\
(G W h)\end{array}$ & $\begin{array}{c}\Delta \text { Capacity } \\
\text { Factor }^{d} \\
(\%)\end{array}$ \\
\hline \multirow[t]{8}{*}{2008} & Facility J & $\begin{array}{l}148.0 \\
(2,268)\end{array}$ & 993.7 & 76.6 & -384.9 & $\begin{array}{l}-29.7 \\
(-1.9)\end{array}$ & .237 .8 & $\begin{array}{l}-18.3 \\
(-1.2)\end{array}$ & .59 .7 & $\begin{array}{c}-4.6 \\
(-0.3)\end{array}$ \\
\hline & Facility K & $1,263.6$ & $7,080.1$ & 64.0 & 109.8 & 1.0 & 217.5 & 2.0 & 51.3 & 0.5 \\
\hline & Facility L & 446.2 & $2,779.7$ & 71.1 & .66 .2 & -1.7 & 22.5 & 0.6 & 34.4 & 0.9 \\
\hline & Facility M & $\begin{array}{c}420.6 \\
(1,650)\end{array}$ & $2,806.2$ & 76.2 & 307.2 & $\begin{array}{c}8.3 \\
(2.1)\end{array}$ & 300.0 & $\begin{array}{l}8.1 \\
(2.1)\end{array}$ & 154.2 & $\begin{array}{c}4.2 \\
(1.1)\end{array}$ \\
\hline & Facility $N$ & 235.0 & $1,661.5$ & 78.3 & 153.2 & 7.4 & 103.4 & 5.0 & -26.1 & -1.3 \\
\hline & Facility 0 & $\begin{array}{r}42.0 \\
(1,572)\end{array}$ & 277.6 & 75.5 & 1.6 & $\begin{array}{c}0.4 \\
(0.0)\end{array}$ & 3.5 & $\begin{array}{c}0.9 \\
(0.0)\end{array}$ & 0.8 & $\begin{array}{c}0.2 \\
(0.0)\end{array}$ \\
\hline & Facility P & $\begin{array}{l}31.0 \\
(400)\end{array}$ & 212.1 & 78.1 & 24.9 & $\begin{array}{c}9.2 \\
(0.7)\end{array}$ & 19.9 & $\begin{array}{c}7.3 \\
(0.6)\end{array}$ & -20.8 & $\begin{array}{l}-7.7 \\
(-0.6)\end{array}$ \\
\hline & Facility Q & $\begin{array}{r}81.9 \\
(1,338)\end{array}$ & 604.3 & 84.2 & 35.4 & $\begin{array}{c}4.9 \\
(0.3)\end{array}$ & 35.2 & $\begin{array}{c}4.9 \\
(0.3)\end{array}$ & .20 .0 & $\begin{array}{l}-2.8 \\
(-0.2)\end{array}$ \\
\hline
\end{tabular}

a Listed are only the existing plants with one or more generating units having more than a $10 \%$ capacity factor change from the no-action alternative case in any one of the three years.

b The number of intermediate and baseload units included in Facilities $\mathrm{J}$ through $\mathrm{Q}$ ranges from 1 to 3 .

c Numbers in parentheses are total generating capacity of all units at the plant.

d Numbers in parentheses are capacity factor changes with respect to the total generating capacity of all units at the plant. 
TABLE 16 Changes in Annual Generation and Capacity Factor of New Peaking Units under Selected

Commitment-Level Alternatives in 1998 and $2008^{\mathrm{a}}$

\begin{tabular}{|c|c|c|c|c|c|c|c|c|c|c|c|}
\hline \multirow[b]{2}{*}{ Year } & \multirow[b]{2}{*}{$\begin{array}{l}\text { Utility } \\
\text { Pool }\end{array}$} & \multirow[b]{2}{*}{ Unit Type } & \multirow[b]{2}{*}{$\begin{array}{l}\text { Capacity } \\
(M W)\end{array}$} & \multicolumn{2}{|c|}{ No Action } & \multicolumn{2}{|c|}{$\begin{array}{l}\text { High Capacity, } \\
\text { Low Energy }\end{array}$} & \multicolumn{2}{|c|}{$\begin{array}{l}\text { Low Capacity, } \\
\text { Low Energy }\end{array}$} & \multicolumn{2}{|c|}{$\begin{array}{l}\text { Low Capacity, } \\
\text { High Energy }\end{array}$} \\
\hline & & & & $\begin{array}{l}\text { Annual } \\
\text { Generation } \\
(G W h)\end{array}$ & $\begin{array}{c}\text { Capacity } \\
\text { Factor } \\
(\%)\end{array}$ & $\begin{array}{c}\Delta \text { Annual } \\
\text { Generation } \\
(G W h)\end{array}$ & $\begin{array}{c}\Delta \text { Capacity } \\
\text { Factor. } \\
\text { (\%) }\end{array}$ & $\begin{array}{c}\Delta \text { Annual } \\
\text { Generation } \\
(G W h)\end{array}$ & $\begin{array}{c}\Delta \text { Capacity } \\
\text { Factor } \\
(\mathscr{D})\end{array}$ & $\begin{array}{c}\Delta \text { Annual } \\
\text { Generation } \\
(G W h)\end{array}$ & $\begin{array}{c}\Delta \text { Capacity } \\
\text { Factor } \\
\text { (\%) }\end{array}$ \\
\hline \multirow[t]{6}{*}{1998} & Pool A & Gas turbine & 65.0 & 0.0 & 0.0 & 0.0 & 0.0 & 94.4 & 16.6 & 0.0 & 0.0 \\
\hline & Pool B & Gas turbine & 68.7 & 0.0 & 0.0 & 0.0 & 0.0 & 100.9 & 16.8 & 85.5 & 14.2 \\
\hline & Pool C & Gas turbine & 25.9 & 0.0 & 0.0 & 0.0 & 0.0 & 59.3 & 26.1 & 35.5 & 15.7 \\
\hline & Pool $\mathrm{C}$ & Gas turbine & 25.9 & 0.0 & 0.0 & 0.0 & 0.0 & 30.3 & 13.4 & 17.5 & 7.7 \\
\hline & Pool D & Diesel engine & 11.0 & 0.0 & 0.0 & 0.0 & 0.0 & 22.3 & 23.1 & 0.0 & 0.0 \\
\hline & Pool E & Diesel engine & 2.2 & 2.1 & 10.8 & -2.1 & -10.8 & -2.1 & -10.8 & -2.1 & -10.8 \\
\hline \multirow[t]{12}{*}{2008} & Pool A & Gas turbine & 65.0 & 0.0 & 0.0 & 130.9 & 23.0 & 145.7 & 25.6 & 96.8 & 17.0 \\
\hline & Pool A & Gas turbine & 65.0 & 0.0 & 0.0 & 0.0 & 0.0 & 145.7 & 25.6 & 96.8 & 17.0 \\
\hline & Pool B & Gas turbine & 68.7 & 0.0 & 0.0 & 0.0 & 0.0 & 61.1 & 10.2 & 53.8 & 8.9 \\
\hline & Pool C & Gas turbine & 16.7 & 20.8 & 14.2 & 29.4 & 20.1 & -13.3 & -9.1 & -10.5 & .7 .2 \\
\hline & Pool C & Gas turbine & 25.9 & 0.0 & 0.0 & 0.0 & 0.0 & 53.0 & 23.4 & 59.7 & 26.3 \\
\hline & Pool C & Gas turbine & 25.9 & 0.0 & 0.0 & 0.0 & 0.0 & 22.4 & 9.9 & 30.1 & 13.3 \\
\hline & Pool D & Diesel engine & 11.0 & 0.0 & 0.0 & 0.0 & 0.0 & 19.9 & 20.7 & 0.0 & 0.0 \\
\hline & Pool E & Gas turbine & 7.7 & 0.0 & 0.0 & 11.8 & 17.5 & 7.0 & 10.3 & 7.2 & 10.7 \\
\hline & Pool E & Diesel engine & 1.5 & 0.0 & 0.0 & 0.0 & 0.0 & 0.0 & 0.0 & 3.5 & 27.0 \\
\hline & Pool E & Diesel engine & 2.2 & 2.9 & 15.2 & -2.9 & -15.2 & -2.9 & -15.2 & .2 .9 & -15.2 \\
\hline & Pool E & Diesel engine & 2.2 & 2.9 & 15.2 & .2 .9 & .15 .2 & .2 .9 & -15.2 & -2.9 & -15.2 \\
\hline & Pool E & Diesel engine & 2.9 & 0.0 & 0.0 & 0.0 & 0.0 & 7.0 & 27.7 & 0.0 & 0.0 \\
\hline
\end{tabular}

a Listed are only the units having more than a $10 \%$ capacity factor change from the no-action alternative case in any one of the three years. 
TABLE 17 Changes in Annual Generation and Capacity Factor of New Intermediate and Baseload Units under Selected Commitment-Level Alternatives in 1998 and $2008^{\mathrm{a}}$

\begin{tabular}{|c|c|c|c|c|c|c|c|c|c|c|c|}
\hline \multirow[b]{2}{*}{ Year } & \multirow[b]{2}{*}{$\begin{array}{l}\text { Utility } \\
\text { Pool }\end{array}$} & \multirow[b]{2}{*}{ Unit Type } & \multirow[b]{2}{*}{$\begin{array}{l}\text { Capacity } \\
\text { (MW) }\end{array}$} & \multicolumn{2}{|c|}{ No Action } & \multicolumn{2}{|c|}{$\begin{array}{l}\text { High Capacity, } \\
\text { Low Energy }\end{array}$} & \multicolumn{2}{|c|}{$\begin{array}{l}\text { Low Capacity, } \\
\text { Low Energy }\end{array}$} & \multicolumn{2}{|c|}{$\begin{array}{l}\text { Low Capacity, } \\
\text { High Energy }\end{array}$} \\
\hline & & & & $\begin{array}{l}\text { Annual } \\
\text { Generation } \\
\text { (GWh) }\end{array}$ & $\begin{array}{l}\text { Capacity } \\
\text { Factor } \\
(\%)\end{array}$ & $\begin{array}{c}\Delta \text { Annual } \\
\text { Generation } \\
\text { (GWh) }\end{array}$ & $\begin{array}{c}\Delta \text { Capacity } \\
\text { Factor } \\
(\%)\end{array}$ & $\begin{array}{c}\Delta \text { Annual } \\
\text { Generation } \\
\text { (GWh) }\end{array}$ & $\begin{array}{c}\Delta \text { Capacity } \\
\text { Factor } \\
(\%)\end{array}$ & $\begin{array}{c}\Delta \text { Annual } \\
\text { Generation } \\
\text { (GWh) }\end{array}$ & $\begin{array}{c}\Delta \text { Capacity } \\
\text { Factor } \\
(\%)\end{array}$ \\
\hline \multirow[t]{2}{*}{1998} & Pool D & Comb. cycle ${ }^{b}$ & 13.7 & 0.0 & 0.0 . & 108.6 & 90.5 & 104.4 & 87.0 & 76.2 & 63.5 \\
\hline & Pool F & Comb. cycle & 186.0 & 0.0 & 0.0 & 706.6 & 43.3 & 0.0 & 0.0 & 0.0 & 0.0 \\
\hline \multirow[t]{8}{*}{2008} & Pool C & Comb. cycle & 13.2 & 0.0 & 0.0 & 80.0 & 69.2 & 74.7 & 64.6 & 0.0 & 0.0 \\
\hline & Pool C & Comb. cycle & 13.2 & 0.0 & 0.0 & 0.0 & 0.0 & 69.9 & 60.5 & 0.0 & 0.0 \\
\hline & Pool D & Comb. cycle & 13.7 & 41.8 & 34.9 & 56.3 & 46.9 & 46.7 & 38.9 & 20.4 & 17.0 \\
\hline & Pool D & Comb. cycle & 13.7 & 22.1 & 18.4 & 45.7 & 38.1 & 48.2 & 40.1 & 18.4 & 15.3 \\
\hline & Pool D & Comb. cycle & 13.7 & 0.0 & 0.0 & 38.1 & 31.8 & 41.4 & 34.5 & 21.8 & 18.1 \\
\hline & Pool $F$ & Comb. cycle & 186.0 & 0.0 & 0.0 & 595.2 & 36.5 & 0.0 & 0.0 & 0.0 & 0.0 \\
\hline & Pool G & Comb. cycle & 13.2 & 0.0 & 0.0 & 83.8 & 72.4 & 0.0 & 0.0 & 0.0 & 0.0 \\
\hline & Pool G & Comb. cycle & 44.0 & 167.1 & 43.4 & -167.1 & -43.4 & -167.1 & .43 .4 & -167.1 & -43.4 \\
\hline
\end{tabular}

a Listed are only the units having more than a $10 \%$ capacity factor change from the no-action alternative case in any one of the three years.

b Comb. cycle $=$ Combined cycle. 
years evaluated are all coal-fired plants that have a total plant generating capacity between 235 and 2,268 MW (Table 15) and are located in rural areas in Colorado, New Mexico, Utah or Wyoming. The percent changes in annual capacity factor from the no-action alternative (on a plantwide basis) are 5\% or less, except for one plant with an annual capacity factor change ranging from $-1.3 \%$ under the low-capacity, high-energy alternative in 2008 to $11.3 \%$ under the high-capacity, low-energy alternative in 1998. However, potential impacts on ambient air quality of this amount of change in annual capacity factor is expected to be minor because the total generating capacity of the plant is relatively small and because it meets the New Source Performance Standards. (See the appendix, Table A.4, for the estimated ambient air quality impacts for similar plants.)

The projected new peaking units having more than a $10 \%$ change in annual capacity factor relative to the no-action alternative during 1998 and 2008 include gas turbines with a unit generating capacity between 8 and $69 \mathrm{MW}$ and diesel engines with a unit generating capacity between 1.5 and $11 \mathrm{MW}$. The percent changes in annual capacity factor relative to the no-action alternative range from -11 to $0 \%$ for the high-capacity, low-energy alternative in 1993 to -15 to $28 \%$ for the low-capacity, low-energy alternative in 2008 (Table 16). However, none of these units have annual capacity factors greater than $28 \%$ in 1998 or 2008. Because air quality impacts of these peaking units are small, even at a $100 \%$ annual capacity factor, the projected changes in annual capacity factors of these plants are not expected to result in any significant ambient air quality impacts. (See the appendix, Tables A.1 and A.2, for the estimated ambient air quality impacts for similar plants.)

The projected new intermediate and baseload units having more than a 10\% change in annual capacity factor from the no-action alternative case during 1998 and 2008 are all gas-fired combined-cycle units with a unit generating capacity between 13 and $186 \mathrm{MW}$ (Table 17). The percent changes in annual capacity factor from the no-action alternative case are -43 to $18 \%$ for the low-capacity, high-energy alternative in 2008 to 43 to $91 \%$ for the highcapacity, low-energy alternative in 1993. Because air quality impacts of these gas-fired combined-cycle units are small, even at a $100 \%$ annual capacity factor, the projected changes in annual capacity factors of these plants are not expected to result in any significant ambient air quality impacts. (See the appendix, Table A.3, for the estimated ambient air quality impacts for similar plants.)

\subsubsection{Regional Air Quality}

The estimated impacts of commitment-level alternatives and supply options on annual air pollutant emissions from the region's 17 utility systems are presented in Table 18. In general, the emissions of $\mathrm{SO}_{2}$ and TSP projected for the low-capacity, high-energy alternative show slightly higher values than under the no-action alternative, but those for the high-capacity, low-energy and low-capacity, low-energy alternatives show slightly lower values than under the no-action alternative. However, no clear trends are observed in the projected emissions of $\mathrm{NO}_{\mathrm{x}}$ and $\mathrm{CO}_{2}$. 
The maximum changes in the regional annual emissions from the baseline (supply option $\mathrm{A} / \mathrm{no}$-action alternative) are projected to be a decrease of 8,200 tons in $\mathrm{SO}_{2}$ (supply option C/high-capacity, low-energy alternative in 1998), an increase of 3,700 tons in $\mathrm{NO}_{\mathrm{x}}$ (supply option A/low-capacity, low-energy alternative in 2008), a decrease of 2,400 tons in TSP (supply option C/high-capacity, low-energy alternative in 1998), and a decrease of 261,000 tons in $\mathrm{CO}_{2}$ (supply option $\mathrm{C} /$ low-capacity, low-energy alternative in 1993). Although these changes in projected regional emissions are significant in their absolute values, they represent a maximum of about $2 \%$ or less of existing emission levels $(-2.2 \%, 0.7 \%,-1.5 \%$, and $-0.8 \%$ for $\mathrm{SO}_{2}, \mathrm{NO}_{\mathrm{x}}, \mathrm{TSP}$, and $\mathrm{CO}_{2}$, respectively). Because these emissions would be released over a very large area, their potential impacts on regional air quality would be small.

\subsubsection{Supply Options}

The proposed supply options (combinations of hydroelectric plant operational scenarios) were also assessed for potential impacts on local and regional air quality of the study region and on regional emissions of greenhouse gases. This assessment was made on the basis of the results of the same analyses conducted for assessing the potential impacts of Western's commitment-level alternatives (Section 4.1.1). The only difference was to compare data among supply options $\mathrm{A}, \mathrm{B}$, and $\mathrm{C}$ rather than among commitment-level alternatives.

\subsubsection{Local Air Quality}

Potential impacts of Western's commitment-level alternatives on local air quality were analyzed on the basis of the data for electric energy produced by the region's individual generating units under selected commitment-level alternatives, as projected by power systems modeling (Section 4.1.1). Because this power systems modeling was not specifically performed to evaluate potential effects of Western's supply options on the electric energy produced by individual generating units, such effects were estimated by comparing the effects of commitment-level alternatives and supply options on the total electric energy produced from nonhydroelectric units. (It was assumed that the smaller the effects on total electric energy production from nonhydroelectric units, the smaller the effects on electric energy generation from individual generating units.)

The projected effects of supply options on total electric energy produced from nonhydroelectric units are small, with projected changes relative to supply option A ranging from 0.0 to $0.6 \%$ for supply option $\mathrm{C}$ and from -0.1 to $0.7 \%$ for supply option B. These projected effects are in the same order of magnitude as those of commitment-level alternatives, with projected changes relative to the no-action alternative ranging from -0.3 to $0.2 \%$ for the high-capacity, low-energy alternative to -0.2 to $0.9 \%$ for the low-capacity and low-energy alternative. Therefore, the differences in electric energy production at individual generating units and associated local air quality impacts under supply options A, B, and C were estimated to be similar to the differences among commitment-level alternatives, which are considered not significant (Section 4.1.1). 
TABLE 18 Annual Emissions of $\mathrm{SO}_{2}, \mathrm{NO}_{\mathbf{x}}$, TSP, and $\mathrm{CO}_{2}$ from Electric Energy Generated by 17 Utility Systems under Selected Commitment-Level Alternatives for 1993, 1998, and 2008

\begin{tabular}{|c|c|c|c|c|c|c|c|c|c|c|c|}
\hline \multirow[b]{2}{*}{ Pollutant } & \multirow[b]{2}{*}{$\begin{array}{l}\text { Supply } \\
\text { Option }\end{array}$} & \multirow[b]{2}{*}{ Alternative } & \multicolumn{3}{|c|}{1993} & \multicolumn{3}{|c|}{1998} & \multicolumn{3}{|c|}{2008} \\
\hline & & & $\begin{array}{c}\text { Annual } \\
\text { Emissions } \\
\left(10^{3} \text { tons }\right)^{\mathrm{a}}\end{array}$ & $\begin{array}{l}\text { Annual } \\
\text { Emission } \\
\text { Change } \\
\left(10^{3} \text { tons }\right)\end{array}$ & $\begin{array}{l}\text { Percent } \\
\text { Change }^{b}\end{array}$ & $\begin{array}{c}\text { Annual } \\
\text { Emissions } \\
\left(10^{3} \text { tons }\right)^{\mathrm{a}}\end{array}$ & $\begin{array}{c}\text { Annual } \\
\text { Emission } \\
\text { Change } \\
\left(10^{3} \text { tons }\right)\end{array}$ & $\begin{array}{l}\text { Percent } \\
\text { Change }^{\mathrm{b}}\end{array}$ & $\begin{array}{c}\text { Annual } \\
\text { Emissions } \\
\left(10^{3} \text { tons }\right)^{a}\end{array}$ & $\begin{array}{c}\text { Annual } \\
\text { Emission } \\
\text { Change } \\
\left(10^{3} \text { tons }\right)\end{array}$ & $\begin{array}{l}\text { Percent } \\
\text { Change }^{b}\end{array}$ \\
\hline \multirow[t]{15}{*}{$\mathrm{SO}_{2}$} & Option A & No Action & 364 & 0.0 & 0.0 & 375 & 0.0 & 0.0 & 418 & 0.0 & 0.0 \\
\hline & & High Capacity, Low Energy & 361 & .3 .1 & -0.9 & 372 & .3 .5 & -0.9 & 415 & -3.1 & -0.8 \\
\hline & & Low Capacity, Low Energy & 363 & -1.3 & -0.3 & 374 & -1.2 & -0.3 & 418 & -0.9 & -0.2 \\
\hline & & Low Capacity, High Energy & 364 & 0.3 & 0.1 & 376 & 0.6 & 0.2 & 421 & 2.0 & 0.5 \\
\hline & & Average & 363 & -1.0 & .0 .3 & 374 & -1.0 & -0.3 & 418 & -0.5 & .0 .1 \\
\hline & Option B & No Action & 361 & -3.0 & .0 .8 & 373 & -2.3 & -0.6 & 416 & -2.4 & -0.6 \\
\hline & & High Capacity, Low Energy & 359 & .5 .1 & .1 .4 & 369 & -5.5 & -1.5 & 414 & -4.9 & -1.2 \\
\hline & & Low Capacity, Low Energy & 361 & -2.8 & .0 .8 & 372 & -3.0 & .0 .8 & 415 & -2.9 & -0.7 \\
\hline & & Low Capacity, High Energy & 363 & .0 .8 & -0.2 & 375 & .0 .6 & -0.2 & 419 & 0.1 & 0.0 \\
\hline & & Average & 361 & .2 .9 & .0 .8 & 372 & -2.9 & -0.8 & 416 & -2.5 & -0.6 \\
\hline & Option C & No Action & 359 & .4 .9 & .1 .4 & 371 & .4 .5 & -1.2 & 415 & -3.9 & -0.9 \\
\hline & & High Capacity, Low Energy & 356 & .7 .5 & -2.1 & 367 & .8 .2 & .2 .2 & 411 & -7.1 & -1.7 \\
\hline & & Low Capacity, Low Energy & 359 & .5 .2 & .1 .4 & 370 & .5 .6 & -1.5 & 413 & -5.3 & -1.3 \\
\hline & & Low Capacity, High Energy & 362 & -2.2 & -0.6 & 373 & -2.4 & -0.7 & 417 & -1.0 & -0.2 \\
\hline & & Average & 359 & -4.9 & -1.4 & 370 & .5 .2 & -1.4 & 414 & -4.3 & -1.0 \\
\hline \multirow[t]{15}{*}{$\mathrm{NO}_{\mathbf{x}}$} & Option A & No Action & 399 & 0.0 & 0.0 & 429 & 0.0 & 0.0 & 538 & 0.0 & 0.0 \\
\hline & & High Capacity, Low Energy & 397 & .1 .7 & -0.4 & 429 & 0.0 & 0.0 & 539 & 1.3 & 0.2 \\
\hline & & Low Capacity, Low Energy & 396 & -3.4 & .0 .9 & 429 & 0.7 & 0.2 & 541 & 3.7 & 0.7 \\
\hline & & Low Capacity, High Enengy & 397 & -2.1 & -0.5 & 429 & 0.1 & 0.0 & 539 & 1.2 & 0.2 \\
\hline & & Average & 397 & -1.8 & -0.5 & 429 & 0.2 & 0.1 & 539 & 1.6 & 0.3 \\
\hline & Option B & No Action & 398 & -1.1 & .0 .3 & 429 & -0.2 & .0 .1 & 537 & -0.9 & -0.2 \\
\hline & & High Capacity, Low Energy & 399 & 0.2 & 0.0 & 429 & 0.3 & 0.1 & 539 & 1.6 & 0.3 \\
\hline & & Low Capacity, Low Energy & 396 & -3.1 & .0 .8 & 429 & 0.6 & 0.1 & 541 & 3.3 & 0.6 \\
\hline & & Low Capacity, High Energy & 397 & .1 .7 & .0 .4 & 429 & 0.3 & 0.1 & 537 & 0.0 & 0.0 \\
\hline & & Average & 398 & -1.4 & -0.4 & 429 & 0.2 & 0.1 & 539 & 1.0 & 0.2 \\
\hline & Option C & No Action & 399 & .0 .4 & .0 .1 & 427 & -1.6 & -0.4 & 536 & -1.5 & -0.3 \\
\hline & & High Capacity, Low Energy & 401 & 1.6 & 0.4 & 428 & .0 .6 & .0 .1 & 538 & 0.9 & 0.2 \\
\hline & & Low Capacity, Low Energy & 395 & .3 .6 & 0.9 & 427 & -1.2 & -0.3 & 539 & 1.9 & 0.3 \\
\hline & & Low Capacity, High Energy & 397 & .2 .0 & -0.5 & 427 & .1 .2 & -0.3 & 537 & -0.5 & -0.1 \\
\hline & & Average & 398 & -1.1 & .0 .3 & 427 & -1.2 & 0.3 & 538 & 0.2 & 0.0 \\
\hline
\end{tabular}


TABLE 18 (Cont.)

\begin{tabular}{|c|c|c|c|c|c|c|c|c|c|c|c|}
\hline \multirow[b]{2}{*}{ Pollutant } & \multirow[b]{2}{*}{$\begin{array}{l}\text { Supply } \\
\text { Option }\end{array}$} & \multirow[b]{2}{*}{ Alternative } & \multicolumn{3}{|c|}{1993} & \multicolumn{3}{|c|}{1998} & \multicolumn{3}{|c|}{2008} \\
\hline & & & $\begin{array}{c}\text { Annual } \\
\text { Emissions } \\
\left(10^{3} \text { tons }\right)^{\mathbf{a}}\end{array}$ & $\begin{array}{c}\text { Annual } \\
\text { Emission } \\
\text { Change } \\
\left(10^{3} \text { tons }\right)\end{array}$ & $\begin{array}{l}\text { Percent } \\
\text { Change }^{b}\end{array}$ & $\begin{array}{c}\text { Annual } \\
\text { Emissions } \\
\left(10^{3} \text { tons }\right)^{2}\end{array}$ & $\begin{array}{c}\text { Annual } \\
\text { Emission } \\
\text { Change }{ }^{2, b} \\
\left(10^{3} \text { tons }\right)\end{array}$ & $\begin{array}{l}\text { Percent } \\
\text { Change }^{b}\end{array}$ & $\begin{array}{c}\text { Annual } \\
\text { Emissions } \\
\left(10^{3} \text { tons }\right)^{k}\end{array}$ & $\begin{array}{l}\text { Annual } \\
\text { Emission } \\
\text { Change } \\
\left(10^{9} \text { tons }\right)\end{array}$ & $\begin{array}{l}\text { Percent } \\
\text { Change }^{b}\end{array}$ \\
\hline \multirow{15}{*}{ TSP } & Option A & No Action & 169 & 0.0 & 0.0 & 166 & 0.0 & 0.0 & 163 & 0.0 & 0.0 \\
\hline & & High Capacity, Low Enengy & 168 & -0.8 & -0.5 & 166 & -0.8 & .0 .5 & 162 & -0.4 & -0.2 \\
\hline & & Low Capacity, Low Energy & 169 & -0.2 & -0.1 & 166 & -0.4 & 0.2 & 163 & -0.1 & -0.1 \\
\hline & & Low Capacity, High Enemgy & 170 & 0.5 & 0.3 & 167 & 0.4 & 0.3 & 164 & 0.9 & 0.6 \\
\hline & & Average & 169 & -0.1 & -0.1 & 166 & -0.2 & .0 .1 & 163 & 0.1 & 0.1 \\
\hline & Option B & No Action & 168 & -0.8 & -0.5 & 166 & -0.6 & 0.4 & 162 & -0.6 & -0.4 \\
\hline & & High Capacity, Low Energy & 168 & -1.7 & .1 .0 & 165 & .1 .6 & .1 .0 & 162 & -1.1 & -0.7 \\
\hline & & Low Capacity, Low Energy & 168 & -1.0 & .0 .6 & 165 & -1.2 & .0 .7 & 162 & -0.8 & .0 .5 \\
\hline & & Low Capacity, High Energy & 169 & -0.1 & .0 .1 & 167 & -0.1 & .0 .1 & 163 & 0.2 & 0.1 \\
\hline & & Average & 168 & .0 .9 & .0 .5 & 166 & .0 .9 & .0 .5 & 162 & .0 .6 & .0 .4 \\
\hline & Option C & No Action & 168 & -1.6 & -0.9 & 165 & -1.5 & 0.9 & 162 & -1.1 & -0.7 \\
\hline & & High Capacity, Low Energy & 167 & -2.4 & -1.4 & 164 & -2.4 & -1.5 & 161 & -1.6 & -1.0 \\
\hline & & Low Capacity, Low Energy & 167 & -1.7 & -1.0 & 165 & .2 .0 & -1.2 & 161 & .1 .4 & .0 .9 \\
\hline & & Low Capacity, High Energy & 168 & -0.8 & -0.5 & 165 & .1 .0 & 0.6 & 162 & -0.3 & -0.2 \\
\hline & & Average & 168 & -1.6 & -1.0 & 165 & -1.7 & -1.0 & 162 & -1.1 & .0 .7 \\
\hline \multirow[t]{15}{*}{$\mathrm{CO}_{2}$} & Option A & No Action & 341 & 0.0 & 0.0 & 380 & 0.0 & 0.0 & 489 & 0.0 & 0.0 \\
\hline & & High Capacity, Low Energy & 340 & -1.0 & -0.3 & 380 & .0 .1 & 0.0 & 489 & -0.1 & 0.0 \\
\hline & & Low Capacity, Low Energy & 339 & .2 .1 & .0 .6 & 378 & -1.3 & .0 .3 & 489 & -1.0 & .0 .2 \\
\hline & & Low Capacity, High Energy & 340 & -1.5 & .0 .4 & 379 & -0.8 & .0 .2 & 490 & 0.5 & 0.1 \\
\hline & & Average & 340 & -1.2 & .0 .3 & 379 & -0.5 & .0 .1 & 489 & .0 .1 & 0.0 \\
\hline & Option B & No Action & 340 & .0 .9 & .0 .3 & 381 & 1.1 & 0.3 & 490 & 0.4 & 0.1 \\
\hline & & High Capacity, Low Energy & 340 & -0.4 & .0 .1 & 381 & 0.9 & 0.2 & 490 & 0.9 & 0.2 \\
\hline & & Low Capacity, Low Energy & 339 & .2 .2 & .0 .6 & 379 & .0 .8 & .0 .2 & 488 & -1.1 & .0 .2 \\
\hline & & Low Capacity, High Energy & 340 & -1.2 & .0 .4 & 381 & 0.9 & 0.2 & 490 & 0.8 & 0.2 \\
\hline & & Average & 340 & -1.2 & .0 .3 & 380 & 0.5 & 0.1 & 490 & 0.3 & 0.1 \\
\hline & Option C & No Action & 341 & -0.4 & 0.1 & 380 & 0.5 & 0.1 & 490 & 0.7 & 0.1 \\
\hline & & High Capacity, Low Energy & 341 & 0.1 & 0.0 & 381 & 1.0 & 0.3 & 491 & 1.0 & 0.2 \\
\hline & & Low Capacity, Low Energy & 339 & .2 .6 & .0 .8 & 378 & -1.9 & .0 .5 & 488 & -1.9 & -0.4 \\
\hline & & Low Capacity, High Energy & 340 & -1.5 & .0 .4 & 379 & -1.0 & .0 .3 & 490 & 0.3 & 0.1 \\
\hline & & Average & 340 & -1.1 & 0.3 & 379 & .0 .4 & .0 .1 & 490 & 0.0 & 0.0 \\
\hline
\end{tabular}

a $10^{5}$ tons for $\mathrm{CO}_{2}$.

b Change from the supply option Ano-action alternative case. 


\subsubsection{Regional Air Quality}

The estimated annual air pollutant emissions from the region's 17 utility systems under Western's selected supply options and their percent changes from supply option A are provided in Table 19. The projected regional emissions of $\mathrm{S.O}_{2}$ and TSP show slight but consistent decreases as flow fluctuations at hydroelectric facilities are reduced from supply option A (high fluctuation) to supply option B (low fluctuation), and from supply option B to supply option $\mathrm{C}$ (steady flows). However, no clear trends are observed in the emissions of $\mathrm{NO}_{\mathrm{x}}$ and $\mathrm{CO}_{2}$.

The maximum projected changes in the regional annual emissions from the baseline (supply option $\mathrm{A} / \mathrm{no}$-action alternative) are as follows: a decrease of 8,200 tons of $\mathrm{SO}_{2}$ (supply option C/high-capacity, low-energy alternative in 1998); an increase of 3,700 tons of $\mathrm{NO}_{\mathrm{x}}$ (supply option A/low-capacity, low-energy alternative in 2008); a decrease of 2,400 tons of TSP (supply option C/high-capacity, low-energy alternative in 1988); and a decrease of 261,000 tons of $\mathrm{CO}_{2}$ (supply option C/low-capacity, low-energy alternative in 1993). The absolute values of these changes in the projected regional emissions, although significant, represent only about $2 \%$ or less of existing emission levels $\left(-2.2 \% \mathrm{SO}_{2}, 0.7 \% \mathrm{NO}_{\mathrm{x}},-1.5 \% \mathrm{TSP}\right.$, and $-0.8 \% \mathrm{CO}_{2}$ ). Because these emissions would be released over a very large area, their potential impacts on regional air quality would be small.

\subsubsection{Cumulative Impacts}

Combustion of fossil fuels results in the emission of criteria air pollutants $\left(\mathrm{SO}_{2}, \mathrm{NO}_{\mathrm{x}}\right.$, $\mathrm{CO}$, and PM) for which NAAQS have been established to protect public health and welfare. Other gases are also emitted, including strong absorbers of infrared radiation known as "greenhouse" gases - such as $\mathrm{CO}_{2}$, methane $\left(\mathrm{CH}_{4}\right)$, and nitrous oxide $\left(\mathrm{N}_{2} \mathrm{O}\right)$ - which contribute to potential global warming. Once emitted into the atmosphere, criteria pollutants do not remain in the atmosphere very long, about 0.02 year for $\mathrm{SO}_{2}$, about 0.02 year or less for $\mathrm{NO}_{\mathrm{x}}$, and about 0.3 year for $\mathrm{CO}$; thus, concentrations of these gases are not likely to cumulate. In contrast, greenhouse gases stay in the atmosphere for a long time, about 100 to 250 years for $\mathrm{CO}_{2}$, and accumulate in the atmosphere (Wuebbles and Edmonds 1991). Under Western's commitment-level alternatives or operational scenarios, no significant variations in regional emissions of criteria air pollutants or $\mathrm{CO}_{2}$ (used as the surrogate for all types of greenhouse gases emitted from fossil-fuel combustion) are predicted (Sections 4.1.1 and 4.1.2), so no significant variations in cumulative impacts are expected.

\subsection{ACOUSTIC ENVIRONMENTi}

\subsubsection{Commitment-Level Alternatives}

Changes in operating levels and the mix of generating units owned by the region's utility systems resulting from Western's commitment-level alternatives could in turn result 
TABLE 19 Annual Emissions of $\mathrm{SO}_{2}, \mathrm{NO}_{x}, \mathrm{TSP}$, and $\mathrm{CO}_{2}$ from Electric Energy Generated by 17 Utility Systems under Selected Operational Scenarios for 1993, 1998, and 2008

\begin{tabular}{|c|c|c|c|c|c|c|c|c|c|c|c|}
\hline \multirow[b]{2}{*}{ Pollutant } & \multirow[b]{2}{*}{ Alternative } & \multirow[b]{2}{*}{$\begin{array}{l}\text { Supply } \\
\text { Option }\end{array}$} & \multicolumn{3}{|c|}{1993} & \multicolumn{3}{|c|}{1998} & \multicolumn{3}{|c|}{2008} \\
\hline & & & $\begin{array}{c}\text { Annual } \\
\text { Emissions } \\
\left(10^{3} \text { tons }\right)^{a}\end{array}$ & $\begin{array}{c}\text { Annual } \\
\text { Emission } \\
\text { Difference, } \\
\left(10^{3} \text { tons }\right)\end{array}$ & $\begin{array}{l}\text { Percent } \\
\text { Change }^{b}\end{array}$ & $\begin{array}{c}\text { Annual } \\
\text { Emissions } \\
\left(10^{3} \text { tons }\right)^{\alpha}\end{array}$ & $\begin{array}{c}\text { Annual } \\
\text { Emission } \\
\text { Difference, } \\
\left(10^{3} \text { tons }\right)\end{array}$ & $\begin{array}{l}\text { Percent } \\
\text { Change }^{b}\end{array}$ & $\begin{array}{c}\text { Annual } \\
\text { Emissions } \\
\left(10^{3} \text { Lons }\right)^{a}\end{array}$ & $\begin{array}{c}\text { Annual } \\
\text { Emission } \\
\text { Difference, } \\
\left(10^{3} \text { tons }\right)\end{array}$ & $\begin{array}{l}\text { Percent } \\
\text { Change }^{b}\end{array}$ \\
\hline \multirow[t]{16}{*}{$\mathrm{SO}_{2}$} & No Action & A & 364 & 0.0 & 0.0 & 375 & 0.0 & 0.0 & 418 & 0.0 & 0.0 \\
\hline & & B & 361 & -3.0 & -0.8 & 373 & -2.3 & -0.6 & 416 & -2.4 & -0.6 \\
\hline & & C & 359 & -4.9 & -1.3 & 371 & -4.5 & -1.2 & 415 & -3.9 & -0.9 \\
\hline & & Average & 361 & -2.7 & .0 .7 & 373 & -2.2 & -0.6 & 416 & -2.1 & -0.5 \\
\hline & High Capacity, Low Energy & A & 361 & -3.1 & .0 .9 & 372 & -3.5 & -0.9 & 415 & -3.1 & -0.8 \\
\hline & & B & 359 & -5.1 & -1.4 & 369 & -5.5 & -1.5 & 414 & -4.9 & -1.2 \\
\hline & & C & 356 & .7 .5 & -2.1 & 367 & -8.2 & .2 .2 & 411 & .7 .1 & -1.7 \\
\hline & & Average & 359 & -5.2 & -1.4 & 369 & -5.7 & -1.5 & 414 & -5.0 & -1.2 \\
\hline & Low Capacity, Low Energy & $\mathrm{A}$ & 363 & -1.3 & .0 .4 & 374 & -1.2 & -0.3 & 418 & .0 .9 & -0.2 \\
\hline & & B & 361 & .2 .8 & .0 .8 & 372 & -3.0 & -0.8 & 415 & -2.9 & -0.7 \\
\hline & & C & 359 & -5.2 & -1.4 & 370 & .5 .6 & -1.5 & 413 & .5 .3 & -1.3 \\
\hline & & Average & 361 & -3.1 & .0 .9 & 372 & -3.3 & -0.9 & 415 & -3.0 & -0.7 \\
\hline & Low Capacity, High Energy & $A$ & 364 & 0.3 & 0.1 & 376 & 0.6 & 0.2 & 421 & 2.0 & 0.5 \\
\hline & & B & 363 & -0.8 & -0.2 & 375 & -0.6 & -0.2 & 419 & 0.1 & 0.0 \\
\hline & & C & 362 & -2.2 & .0 .6 & 373 & .2 .4 & -0.7 & 417 & -1.0 & -0.2 \\
\hline & & Average & 363 & .0 .9 & .0 .3 & 374 & -0.8 & -0.2 & 419 & 0.4 & 0.1 \\
\hline \multirow[t]{16}{*}{$\mathrm{NO}_{x}$} & No Action & A & 399 & 0.0 & 0.0 & 429 & 0.0 & 0.0 & 538 & 0.0 & 0.0 \\
\hline & & B & 398 & -1.1 & .0 .3 & 429 & .0 .2 & -0.1 & 537 & -0.9 & -0.2 \\
\hline & & C & 399 & -0.4 & .0 .1 & 427 & -1.6 & -0.4 & 536 & -1.5 & -0.3 \\
\hline & & Average & 399 & .0 .5 & .0 .1 & 428 & -0.6 & -0.1 & 637 & $-0: 8$ & -0.2 \\
\hline & High Capacity, Low Energy & A & 397 & .1 .7 & -0.4 & 429 & 0.0 & 0.0 & 539 & 1.3 & 0.2 \\
\hline & & B & 399 & 0.2 & 0.0 & 429 & 0.3 & 0.1 & 539 & 1.6 & 0.3 \\
\hline & & $\mathrm{C}$ & 401 & 1.6 & 0.4 & 428 & -0.6 & -0.1 & 538 & 0.9 & 0.2 \\
\hline & & Average & 399 & 0.0 & 0.0 & 429 & .0 .1 & 0.0 & 539 & 1.2 & 0.2 \\
\hline & Low Capacity, Low Energy & A & 396 & .3 .4 & .0 .9 & 429 & 0.7 & 0.2 & 541 & 3.7 & 0.7 \\
\hline & & B & 396 & -3.1 & .0 .8 & 429 & 0.6 & 0.1 & 541 & 3.3 & 0.6 \\
\hline & & c & 395 & .3 .6 & .0 .9 & 427 & -1.2 & -0.3 & 539 & 1.9 & 0.3 \\
\hline & & Average & 396 & .3 .4 & .0 .9 & 429 & 0.0 & 0.0 & 541 & 3.0 & 0.6 \\
\hline & Low Capacity, High Energy & $\mathrm{A}$ & 397 & -2.1 & .0 .5 & 429 & 0.1 & 0.0 & 539 & 1.2 & 0.2 \\
\hline & & B & 397 & .1 .7 & .0 .4 & 429 & 0.3 & 0.1 & 537 & 0.0 & 0.0 \\
\hline & & c & 397 & -2.0 & -0.5 & 427 & -1.2 & -0.3 & 537 & -0.5 & -0.1 \\
\hline & & Average & 397 & -1.9 & .0 .5 & 428 & .0 .3 & -0.1 & 538 & 0.2 & 0.1 \\
\hline
\end{tabular}


TABLE 19 (Cont.)

\begin{tabular}{|c|c|c|c|c|c|c|c|c|c|c|c|}
\hline \multirow[b]{2}{*}{ Pollutant } & \multirow[b]{2}{*}{ Alternative } & \multirow[b]{2}{*}{$\begin{array}{l}\text { Supply } \\
\text { Option }\end{array}$} & \multicolumn{3}{|c|}{1993} & \multicolumn{3}{|c|}{1998} & \multicolumn{3}{|c|}{2008} \\
\hline & & & $\begin{array}{c}\text { Annual } \\
\text { Emissions } \\
\left(10^{3} \text { tons }\right)^{2}\end{array}$ & $\begin{array}{c}\text { Annual } \\
\text { Emission } \\
\text { Difference } \\
\left(10^{3} \text { tons }\right)\end{array}$ & $\begin{array}{l}\text { Percent } \\
\text { Change }\end{array}$ & $\begin{array}{c}\text { Annual } \\
\text { Emissions } \\
\left(10^{3} \text { tons }\right)^{a}\end{array}$ & $\begin{array}{c}\text { Annual } \\
\text { Emission } \\
\text { Difference } \\
\left(10^{3} \text { tons }\right)\end{array}$ & $\begin{array}{l}\text { Percent } \\
\text { Change }^{b}\end{array}$ & $\begin{array}{c}\text { Annual } \\
\text { Emissions } \\
\left(10^{3} \text { tons }\right)^{a}\end{array}$ & $\begin{array}{c}\text { Annual } \\
\text { Emission } \\
\text { Difference } \\
\left(10^{3} \text { tons }\right)\end{array}$ & $\begin{array}{l}\text { Percent } \\
\text { Change }^{b}\end{array}$ \\
\hline \multirow[t]{16}{*}{ TSP } & No Action & A & 169 & 0.0 & 0.0 & 166 & 0.0 & 0.0 & 163 & 0.0 & 0.0 \\
\hline & & B & 168 & .0 .8 & .0 .5 & 166 & -0.6 & .0 .4 & 162 & -0.6 & -0.4 \\
\hline & & C & 168 & .1 .6 & .0 .9 & 165 & -1.5 & -0.9 & 162 & -1.1 & -0.7 \\
\hline & & Average & 168 & -0.8 & .0 .5 & 166 & -0.7 & -0.4 & 162 & -0.6 & -0.4 \\
\hline & High Capacity, Low Energy & A & 168 & -0.8 & .0 .5 & 166 & -0.8 & -0.5 & 162 & -0.4 & -0.2 \\
\hline & & B & 168 & -1.7 & -1.0 & 165 & -1.6 & -1.0 & 162 & -1.1 & -0.7 \\
\hline & & C & 167 & -2.4 & -1.4 & 164 & -2.4 & -1.5 & 161 & -1.6 & -1.0 \\
\hline & & Average & 168 & -1.6 & -1.0 & 165 & -1.6 & -1.0 & 162 & -1.0 & -0.6 \\
\hline & Low Capacity, Low Energy & A & 169 & -0.2 & .0 .1 & 166 & -0.4 & -0.2 & 163 & .0 .1 & -0.1 \\
\hline & & B & 168 & -1.0 & .0 .6 & 165 & .1 .2 & -0.7 & 162 & .0 .8 & -0.5 \\
\hline & & C & 167 & -1.7 & .1 .0 & 165 & -2.0 & -1.2 & 161 & -1.4 & .0 .9 \\
\hline & & Average & 168 & -1.0 & .0 .6 & 165 & -1.2 & -0.7 & 162 & .0 .8 & -0.5 \\
\hline & Low Capacity, High Energy & A & 170 & 0.5 & 0.3 & 167 & 0.4 & 0.3 & 164 & 0.9 & 0.6 \\
\hline & & B & 169 & .0 .1 & -0.1 & 167 & .0 .1 & -0.1 & 163 & 0.2 & 0.1 \\
\hline & & C & 168 & -0.8 & .0 .5 & 165 & -1.0 & -0.6 & $162^{\circ}$ & -0.3 & -0.2 \\
\hline & & Average & 169 & .0 .1 & .0 .1 & 166 & -0.2 & -0.1 & 163 & 0.2 & 0.2 \\
\hline \multirow{16}{*}{$\mathrm{CO}_{2}$} & No Action & $A$ & 341 & 0.0 & 0.0 & 380 & 0.0 & 0.0 & 489 & 0.0 & 0.0 \\
\hline & & B & 340 & -0.9 & .0 .3 & 381 & 1.1 & 0.3 & 490 & 0.4 & 0.1 \\
\hline & & $\mathrm{C}$ & 341 & .0 .4 & .0 .1 & 380 & 0.5 & 0.1 & 490 & 0.7 & 0.1 \\
\hline & & Average & 341 & -0.4 & .0 .1 & 380 & 0.5 & 0.1 & 490 & 0.4 & 0.1 \\
\hline & High Capacity, Low Energy & $A$ & 340 & -1.0 & .0 .3 & 380 & .0 .1 & 0.0 & 489 & -0.1 & 0.0 \\
\hline & & B & 340 & .0 .4 & .0 .1 & 381 & 0.9 & 0.2 & 490 & 0.9 & 0.2 \\
\hline & & $\mathrm{c}$ & 341 & 0.1 & 0.0 & 381 & 1.0 & 0.3 & 491 & 1.0 & 0.2 \\
\hline & & Average & 340 & .0 .5 & -0.1 & 380 & 0.6 & 0.2 & 490 & 0.6 & 0.1 \\
\hline & Low Capacity, Low Energy & A & 339 & -2.1 & .0 .6 & 378 & -1.3 & -0.3 & 489 & -1.0 & -0.2 \\
\hline & & B & 339 & -2.2 & -0.6 & 379 & .0 .8 & -0.2 & 488 & -1.1 & -0.2 \\
\hline & & $\mathrm{C}$ & 339 & .2 .6 & .0 .8 & 378 & -1.9 & .0 .5 & 488 & -1.9 & .0 .4 \\
\hline & & Average & 339 & -2.3 & .0 .7 & 378 & -1.4 & .0 .4 & 488 & -1.3 & -0.3 \\
\hline & Low Capacity, High Energy & $A$ & 340 & -1.5 & .0 .4 & 379 & .0 .8 & .0 .2 & 490 & 0.5 & 0.1 \\
\hline & & B & 340 & -1.2 & .0 .4 & 381 & 0.9 & 0.2 & 490 & 0.8 & 0.2 \\
\hline & & C & 340 & -1.5 & .0 .4 & 379 & -1.0 & -0.3 & 490 & 0.3 & 0.1 \\
\hline & & Average & 340 & .1 .4 & .0 .4 & 379 & .0 .3 & -0.1 & 490 & 0.5 & 0.1 \\
\hline
\end{tabular}

a $10^{5}$ tons for $\mathrm{CO}_{2}$.

b Change from the no-action alternative/supply option $\mathrm{A}$ case. 
in changes in the levels and patterns of noise generation at these units. Because baseload units generally have large capacities and operate continuously, a change in power generation from baseload units would mean a change in load factors rather than a shutting down or starting up of units. As long as the units were in operation, all noise-generating equipment would be in operation, and no significant changes would occur in the level of noise generation. Thus, noise generation from baseload unit operations should change little.

Peaking units generally have relatively small capacities, so a change in power generation from peaking units usually means starting up additional units or shutting down operating units. Even if the number of operating units were changed, the number of such units is estimated to be relatively small at any particular generating facility because the changed peaking power demand would be covered by a number of the region's utility systems. Furthermore, even if all existing peaking units at a particular site were operating, the noise generated would be no higher than the maximum level already experienced at the site. Only the frequency and/or duration of maximum noise levels might increase. However, such increases are generally expected to be relatively small.

The annual capacity factor changes relative to the no-action alternative, which could be used as an indirect measure of changes in the frequency and duration of generating unit operation, are projected to be rather small, ranging on the average from $0 \%$ for the low-capacity, high-energy alternative to $24 \%$ for the low-capacity, low-energy alternative for existing units and from $0 \%$ for the high-capacity, low-energy alternative to $12 \%$ for the lowcapacity, low-energy alternative for projected new units. The maximum changes projected for individual units are $73 \%$ for existing units (Table 14) and 28\% for new units (Table 16). Furthermore, because of the small capacities of peaking units (the capacity of the largest units are $19 \mathrm{MW}$ for existing units and $69 \mathrm{MW}$ for new units), noise impacts of these units are insignificant at locations beyond several hundred feet from the source. In addition, because of the timing of peak demand, such potential noise increases in the immediate vicinity of the peaking units would not occur at night when noise impacts are considered more serious. Thus, changes in commitment-level alternatives are not expected to result in adverse noise impacts in the vicinity of the region's electric power generating facilities whose operations are affected by Western's operations.

\subsubsection{Supply Options}

Major noise sources at hydroelectric generating facilities include turbine generators, step-up transformers, and substation transformers (Section 2.3.2). The number of operating turbine generators and step-up transformers at multiunit facilities (Glen Canyon and Flaming Gorge) would depend on the level of electric power generated because more units would be turned on as more power generation was desired. However, substation transformers are expected to be in continuous operation as long as some level of hydroelectric power is transmitted to the connected power grid.

Because noise production from a given transformer is independent of load (Gordon et al. 1978), noise generation from substation transformers would not be affected by changes 
in the level of hydroelectric generation. Thus, the only change in noise levels at those facilities would result from changes in the number of operating turbine generators and step-up transformers. However, turbine generators and step-up transformers have little effect on noise levels in areas beyond canyon rims because they are located near canyon bottoms and because turbine generators are also enclosed inside concrete plant buildings (Section 2.3.3). Therefore, the diurnal generating patterns of the units would have little impact on the environmental noise levels in areas above canyon rims.

Changes in diurnal generating patterns of hydroelectric facilities could also change the diurnal patterns of noise generation at the region's baseload and peaking units whose operations are affected by Western's operations. As hydroelectric operations changed from high fluctuating releases to steady releases, more electric energy would have to be generated by the region's peaking units during the peak demand period (daytime) and less electric energy from the region's baseload units during off-peak hours (nighttime). Because the changes in the pattern of power plant operations would not result in significant noise impacts in the vicinity of the plant (Section 4.2.1), changes in hydropower operations would not cause any significant noise impacts in the vicinity of the region's electric power generating facilities.

\subsubsection{Cumulative Impacts}

No cumulative noise impacts are expected because noise energy dissipates within short distances from the sources and because significant noise impacts are not expected in the vicinity of Western's hydroelectric plants or the region's other electric generating plants under Western's various commitment-level alternatives or operational scenarios. 


\section{SUMMARY AND CONCLUSIONS}

Analyses to assess potential impacts on local air quality of Western's commitmentlevel alternatives were based on either the magnitude of projected changes in annual capacity factor of the region's existing and projected new individual, nonhydroelectric generating units relative to the no-action alternative, or the magnitude of ambient air quality impacts resulting from such changes in annual capacity factor estimated for similar units. Results of the analyses indicate that the majority of existing and projected new units would have annual capacity factor changes of less than $10 \%$. The few remaining units with projected annual capacity factor changes of more than $10 \%$ were estimated to have only minor ambient air quality impacts as a result of such annual capacity factor changes. Thus, the potential impacts on local air quality of Western's commitment-level alternatives would be minor.

Potential impacts on regional air quality of Western's commitment-level alternatives were evaluated by comparing the estimated annual emissions of selected criteria pollutants $\left(\mathrm{SO}_{2}, \mathrm{NO}_{\mathrm{x}}\right.$, and TSP) and $\mathrm{CO}_{2}$ under Western's various commitment alternatives. Projected changes in annual emissions of these pollutants are about $2 \%$ or less of the values for the no-action alternative/supply option A case, which are not considered significant.

Analyses to assess potential impacts on local air quality of Western's supply options (combination of hydroelectric plant operational scenarios) were based on comparing the magnitude of effects of commitment-level alternatives and supply options on the total electric energy produced from the region's nonhydroelectric units; potential effects of Western's supply options on the electric energy produced by individual generating units were not assessed. The projected effects of Western's supply options from the region's nonhydroelectric units are less than those of the commitment-level alternatives, so it is estimated that the potential impacts on local air quality of Western's supply options are not significant.

Potential impacts on regional air quality of Western's supply options were evaluated by comparing the estimated annual emissions of selected criteria pollutants $\left(\mathrm{SO}_{2}, \mathrm{NO}_{\mathrm{x}}\right.$, and TSP) and $\mathrm{CO}_{2}$ under those supply options. The percent changes in estimated annual air pollutant emissions from the region's utility systems are about $2 \%$ or less from the supply option $\mathrm{A} / \mathrm{no}$-action alternative case. Thus, regional air quality impacts resulting from changes in operational scenarios would be minor.

The criteria pollutants $\left(\mathrm{SO}_{2}, \mathrm{NO}_{\mathrm{x}}, \mathrm{CO}\right.$, and $\mathrm{PM}$ ) have relatively short lifetimes in the atmosphere and therefore do not accumulate; $\mathrm{CO}_{2}$, however, does accumulate in the atmosphere because of its relatively long lifetime there. No significant variations in cumulative impacts are expected under Western's commitment-level alternatives or operational scenarios because no significant variations in regional emissions of criteria pollutants or $\mathrm{CO}_{2}$ are projected to occur.

Changes in operating levels and the mix of generating units owned by the region's utility systems under Western's commitment-level alternatives could result in changes in levels and patterns of noise generation at these units. Because baseload units generally have 
large capacities and operate continuously, a change in power generation from baseload units would mean a change in load factors rather than a shutting down or starting up of units. As long as the units were in operation, all noise-generating equipment would be in operation, and no significant changes in the level of noise generation would occur. Potential changes in frequency and duration of noise generation from peaking units under Western's various commitment-level alternatives are also estimated to be minor, primarily because a change in peaking power demand would be covered by a number of the region's utility systems and only a small number of peaking units would be started up or shut down at any particular generating facility to respond to changing power demand.

Changes in operating scenarios would cause changes in diurnal power generation patterns at individual hydroelectric plants, which in turn would cause changes in diurnal power generation patterns at the region's nonhydroelectric plants. Of the major noise sources at hydroelectric facilities, turbine generators and step-up transformers located at canyon bottoms would contribute little to the noise levels beyond canyon rims. Substation transformers located beyond canyon rims are expected to be in continuous operation as long as some level of hydroelectric power is transmitted to the connected power grid. However, noise production from a given transformer is independent of load, and, therefore, noise generation from substation transformers would not be affected by changes in the level of hydroelectric generation. Potential noise impacts from the changes in diurnal generating patterns at the region's nonhydroelectric generating units are also estimated to be minor for the same reasons given for the potential noise impacts under Western's various commitmentlevel alternatives. 


\section{REFERENCES}

Acoustical Society of America, 1983, American National Standard Specification for Sound Level Meters, ANSI S1.4-1983, New York, N.Y., Feb.

Acoustical Society of America, 1985, American National Standard Specification for Sound Level Meters, ANSI S1.4A-1985, Amendment to ANSI S1.4-1983, New York, N.Y., June.

Cilek, C.M., 1993, "Annual Emissions of Nitrogen Oxides, Sulfur Dioxide, Volatile Organic Compounds, Total Suspended Particulates, and Carbon Dioxide for the Six States in the WAPA EIS Study Region and the United States for the Years 1981 through 1990," memorandum from C.M. Cilek (Argonne National Laboratory, Argonne, Ill.) to K.C. Chun (Argonne National Laboratory, Argonne, Ill.), Feb. 19.

Electrical World, 1993, Directory of Electric Utilities, New York, N.Y.

EPA: see U.S. Environmental Protection Agency.

Flynn, D.R., 1979, "Regulation of New Products Noise Control," in Handbook of Noise Control, 2nd ed., C.M. Harris, (editor), McGraw-Hill Book Co., New York, N.Y., pp. 41-1 to 41-8.

Franklin, A.C., and D.P. Franklin, 1983, The J\&P Transformer Book, 11th ed., Butterworths, London.

Fuller, W.R., and R.Brown, 1981, Analysis and Abatement of Highway Construction Noise, Research Report WR 81-89 (EPA 550/9-81-314a), prepared by Wyle Laboratories, Arlington, Va., for the U.S. Environmental Protection Agency, Office of Noise Abatement and Control, Washington, D.C., Oct.

Gordon, C., et al., 1978, The Development of Procedures for the Prediction of the Core Noise of Power Transformers, Report No. 3697, prepared by Bolt, Beranek and Newman, Inc., Canoga Park, Calif., for Bonneville Power Administration, Portland, Ore., Jan. 27.

Gordon, C., et al., 1980, The Development of Procedures for the Prediction of the Core Noise of Power Transformers (Addendum), Report No. 3697a, prepared by Bolt, Beranek and Newman, Inc., Canoga Park, Calif., for Bonneville Power Administration, Portland, Ore., Nov.

Holzworth, G.C., 1972, Mixing Heights, Wind Speeds, and Potential for Urban Air Pollution throughout the Contiguous United States, Report AP-101, U.S. Environmental Protection Agency, Office of Air Programs, Division of Meteorology, Research Triangle Park, N.C., Jan.

Kohout, E.J., et al., 1990, Current Emission Trends for Nitrogen Oxides, Sulfur Dioxide, and Volatile Organic Compounds by Month and State: Methodology and Results, ANL/EAIS/ TM-25, Argonne National Laboratory, Argonne, nl., Aug. 
Liebich, R.E., 1992, "Ambient Noise Level Spot-Checking at Glen Canyon, Flaming Gorge and Curecanti Sites," memorandum from R.E. Liebich (Argonne National Laboratory, Argonne Ill.) to K.C. Chun (Argonne National Laboratory, Argonne, Ill.), July 2.

Liebich, R.E., and M.P. Cristoforo, 1988, The Use of Audibility Analysis to Minimize Community Noise Impact of Today's Smaller Generation Facilities Located near Residential Areas, presented at American Power Conference 50th Annual Meeting, Chicago, Ill., April.

Malm, W.C., 1989, "Atmospheric Haze: Its Source and Effects on Visibility in Rural Areas of the Continental United States," Environmental Monitoring and Assessment 12:203-225.

Malm, W.C., et al., 1990, "An Investigation of the Dominant Source Regions of Fine Sulfur in the Western United States and Their Areas of Influence," Atmospheric Environment 24A(12):3047-3060.

National Oceanic and Atmospheric Administration, 1990a, Local Climatological Data: Annual Summary with Comparative Data for Flagstaff, Ariz., National Climatic Data Center, Asheville, N.C.

National Oceanic and Atmospheric Administration, 1990b, Local Climatological Data: Annual Summary with Comparative Data for Grand Junction, Colo., National Climatic Data Center, Asheville, N.C.

National Oceanic and Atmospheric Administration, 1990c, Local Climatological Data: Annual Summary with Comparative Data for Las Vegas, Nev., National Climatic Data Center, Asheville, N.C.

National Oceanic and Atmospheric Administration, 1990d, Local Climatological Data: Annual Summary with Comparative Data for Phoenix, Ariz., National Climatic Data Center, Asheville, N.C.

National Oceanic and Atmospheric Administration, 1990e, Local Climatological Data: Annual Summary with Comparative Data for Tucson, Ariz., National Climatic Data Center, Asheville, N.C.

National Oceanic and Atmospheric Administration, 1990f, Local Climatological Data: Annual Summary with Comparative Data for Winslow, Ariz., National Climatic Data Center, Asheville, N.C.

National Oceanic and Atmospheric Administration, 1990g, Local Climatological Data: Annual Summary with Comparative Data for Yuma, Ariz., National Climatic Data Center, Asheville, N.C.

RTA Software Pty, Ltd., 1989, ENM Environmental Noise Model, Sydney, New South Wales, Australia. 
Ruffner, J.A. (editor), 1985, Climates of the States: National Oceanic and Atmospheric Administration Narrative Summaries, Tables and Maps for Each State with Overview of State Climatologist Programs, 3rd ed., Gale Research Co., Detroit, Mich.

Tonin, R., 1985, "Estimating Noise Levels from Petro-chemical Plants, Mines and Industrial Complexes," Acoustics America 13(2):59-67.

Upper Colorado Region State-Federal Inter-Agency Group, 1971, Upper Colorado Region Comprehensive Framework Study, Appendix II, "The Region," prepared for the Pacific Southwest Inter-Agency Committee Water Resource Council by the Upper Colorado Region State-Federal Inter-Agency Group, Salt Lake City, Utah, June.

U.S. Army Corps of Engineers, 1982, Water Control Manual for Flood Control: Hoover Dam and Lake Mead Colorado River, Nevada and Arizona, prepared by the U.S. Army Corps of Engineers, Sacramento District, Dec.

U.S. Environmental Protection Agency, 1974, Information on Levels of Environmental Noise Requisite to Protect Public Health and Welfare with an Adequate Margin of Safety, EPA 550/9-74-004, Office of Noise Abatement and Control, Washington, D.C., March.

U.S. Environmental Protection Agency, 1979, Protecting Visibility, An EPA Report to Congress, EPA-450/5-79-008, Office of Air Quality Planning and Standards, Research Triangle Park, N.C., Oct.

U.S. Environmental Protection Agency, 1986, Industrial Source Complex (ISC) Dispersion Model User's Guide, 2nd ed., Vols. 1 and 2, EPA-450/4-86-005a and EPA-450/4-86-005b, Research Triangle Park, N.C.

U.S. Environmental Protection Agency, 1991, Air Quality Atlas, Air Monitoring Technical Information Center Bulletin Board System, National Air Data Branch, Office of Air Quality Planning and Standards, Research Triangle Park, N.C.

Veselka, T.S, et al., 1995, Impacts of Western Area Power Administration's Power Marketing Alternatives on Electric Utility Systems, ANL/DIS/TM-10, Argonne National Laboratory, Argonne, Ill.

Wuebbles, D.J., and J. Edmonds, 1991, Primer on Greenhouse Gases, Lewis Publishers, Chelesa, Mich. 


\section{APPENDIX: AIR QUALITY}

The existing air quality of the six-state study region considered in this analysis is described in Section 2.2 of the main text, and the potential air quality consequences of Western's commitment-level alternatives and operational scenarios (supply options) are evaluated in Sections 4.1 and 4.2, respectively. The potential cumulative impacts of air pollutant emissions are discussed in Section 4.3. This appendix provides additional information in support of those descriptions and evaluations.

\section{A.1 EXISTING AIR QUALITY}

Figures A.1 through A.7 show the locations of ambient air quality monitoring stations operating within the six-state study region during 1989. These stations monitored sulfur dioxide $\left(\mathrm{SO}_{2}\right)$, nitrogen dioxide $\left(\mathrm{NO}_{2}\right)$, carbon monoxide $(\mathrm{CO})$, ozone $\left(\mathrm{O}_{3}\right)$, particulate matter with an aerodynamic mean of $\leq 10 \mu \mathrm{m}\left(\mathrm{PM}_{10}\right)$, total suspended particulates (TSP), and lead $(\mathrm{Pb})$, respectively.

\section{A.2 AIR QUALITY CONSEQUENCES}

Additional information regarding potential air quality consequences are presented in Tables A.1 through A.4 of this appendix. These tables present estimated air quality impacts from electric power generation from diesel engines, gas turbines, combined-cycle units, and pulverized coal-fired units of various sizes that meet the new source performance standards. 


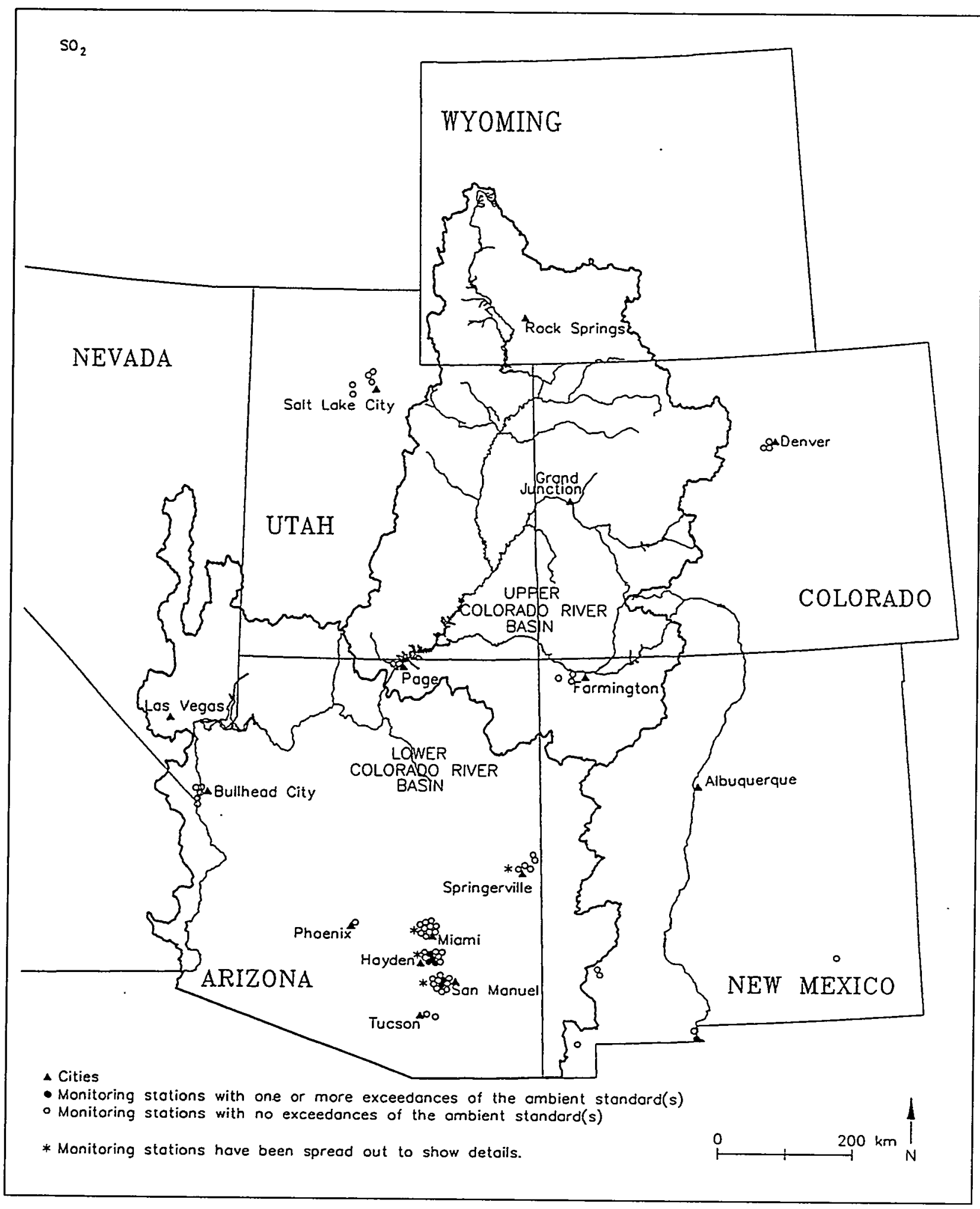

FIGURE A.1 Ambient Air Quality Monitoring Stations for $\mathrm{SO}_{2}$ Operating in 1989 within the Six-State Study Region 


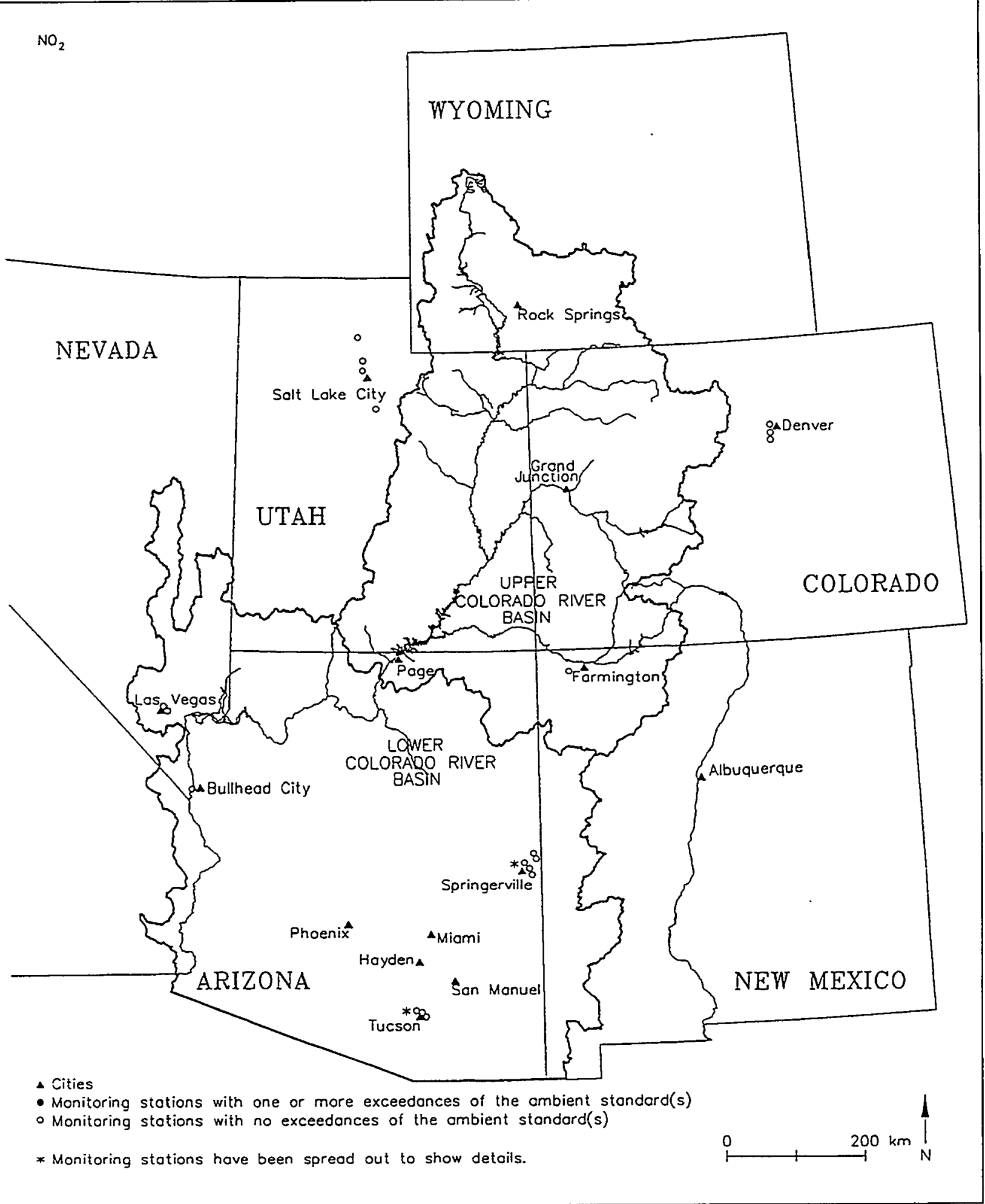

FIGURE A.2 Ambient Air Quality Monitoring Stations for $\mathrm{NO}_{2}$ Operating in 1989 within the Six-State Study Region 


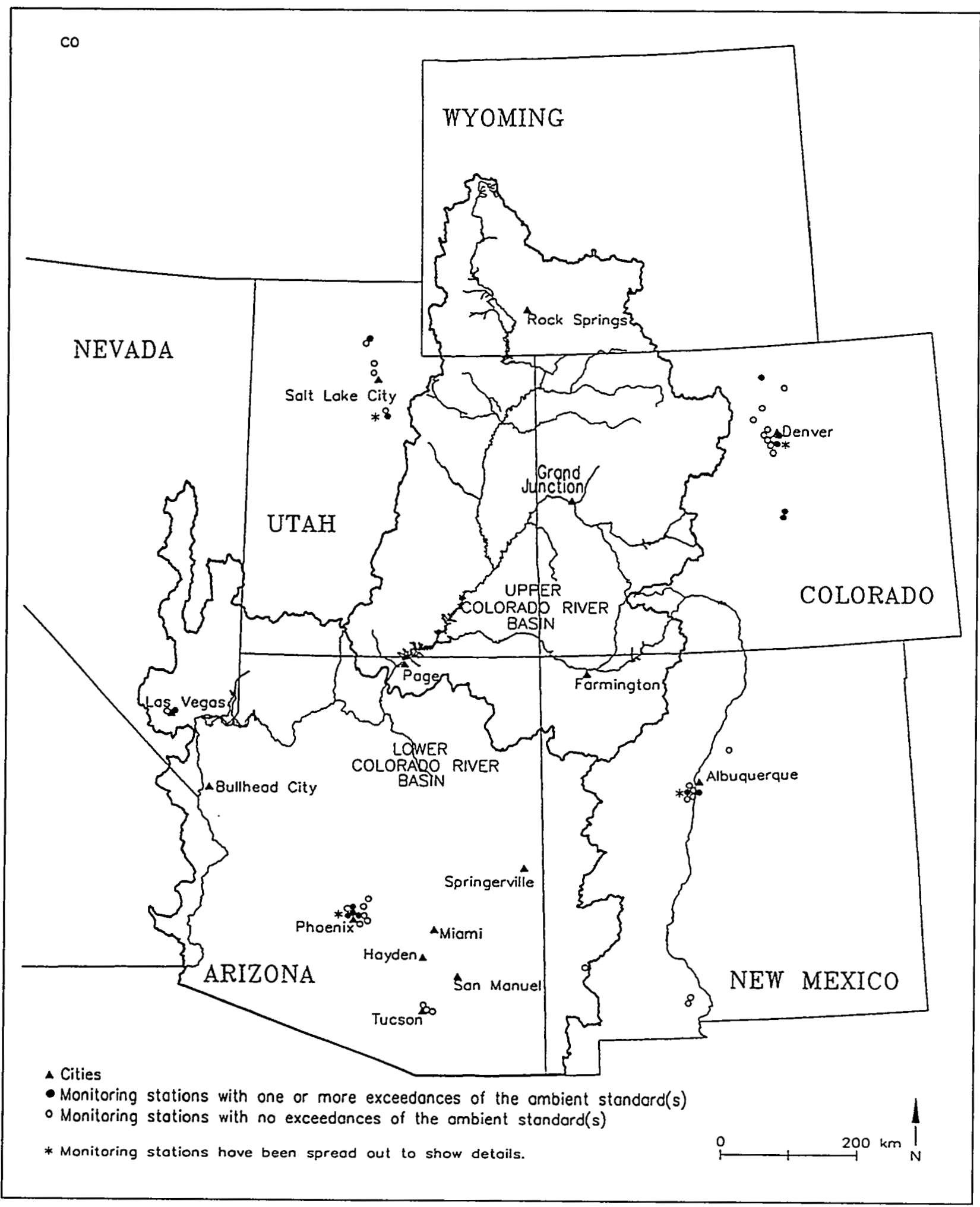

FIGURE A.3 Ambient Air Quality Monitoring Stations for CO Operating in 1989 within the Six-State Study Region 


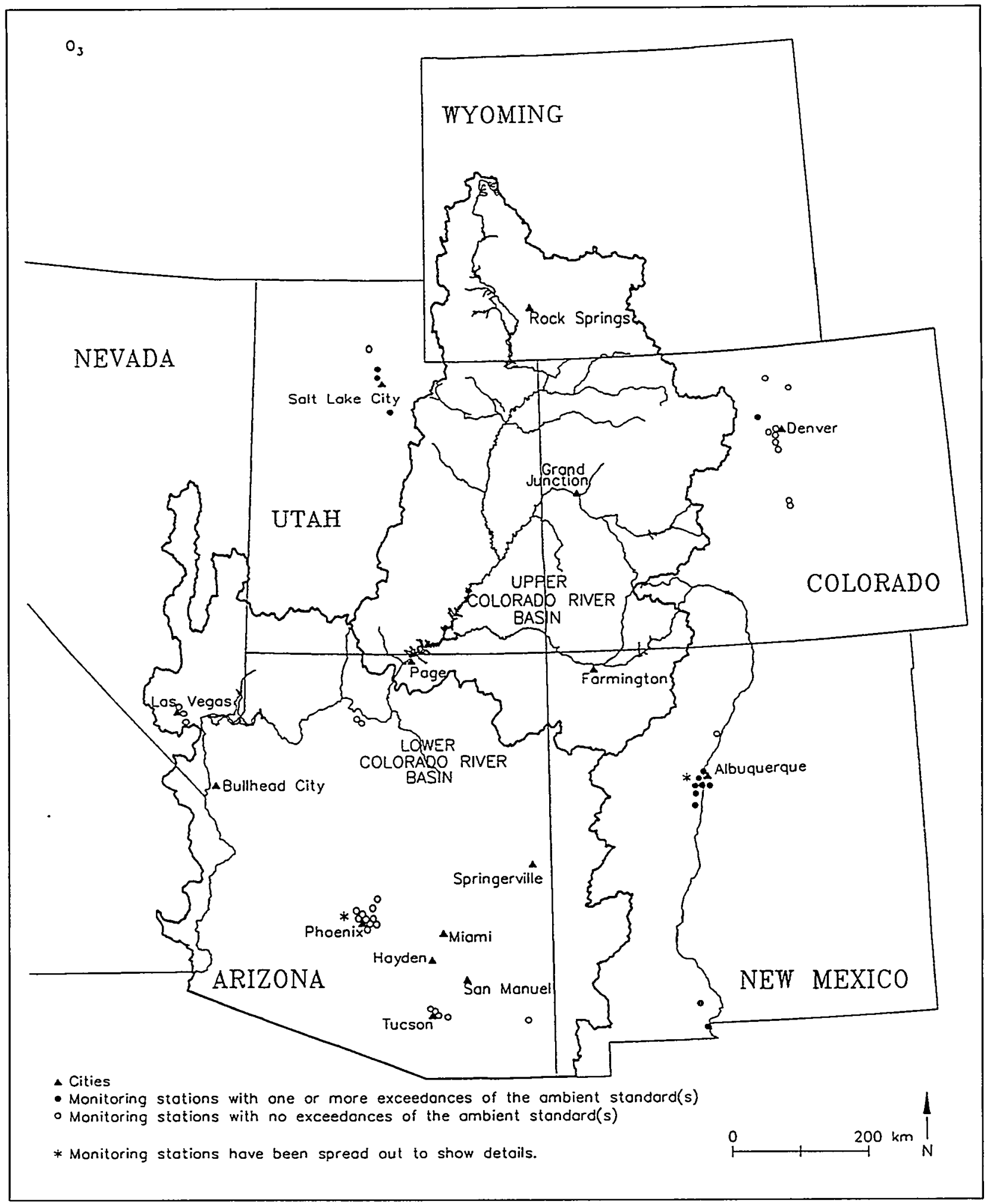

FIGURE A.4 Ambient Air Quality Monitoring Stations for $\mathrm{O}_{3}$ Operating in 1989 within the Six-State Study Region 


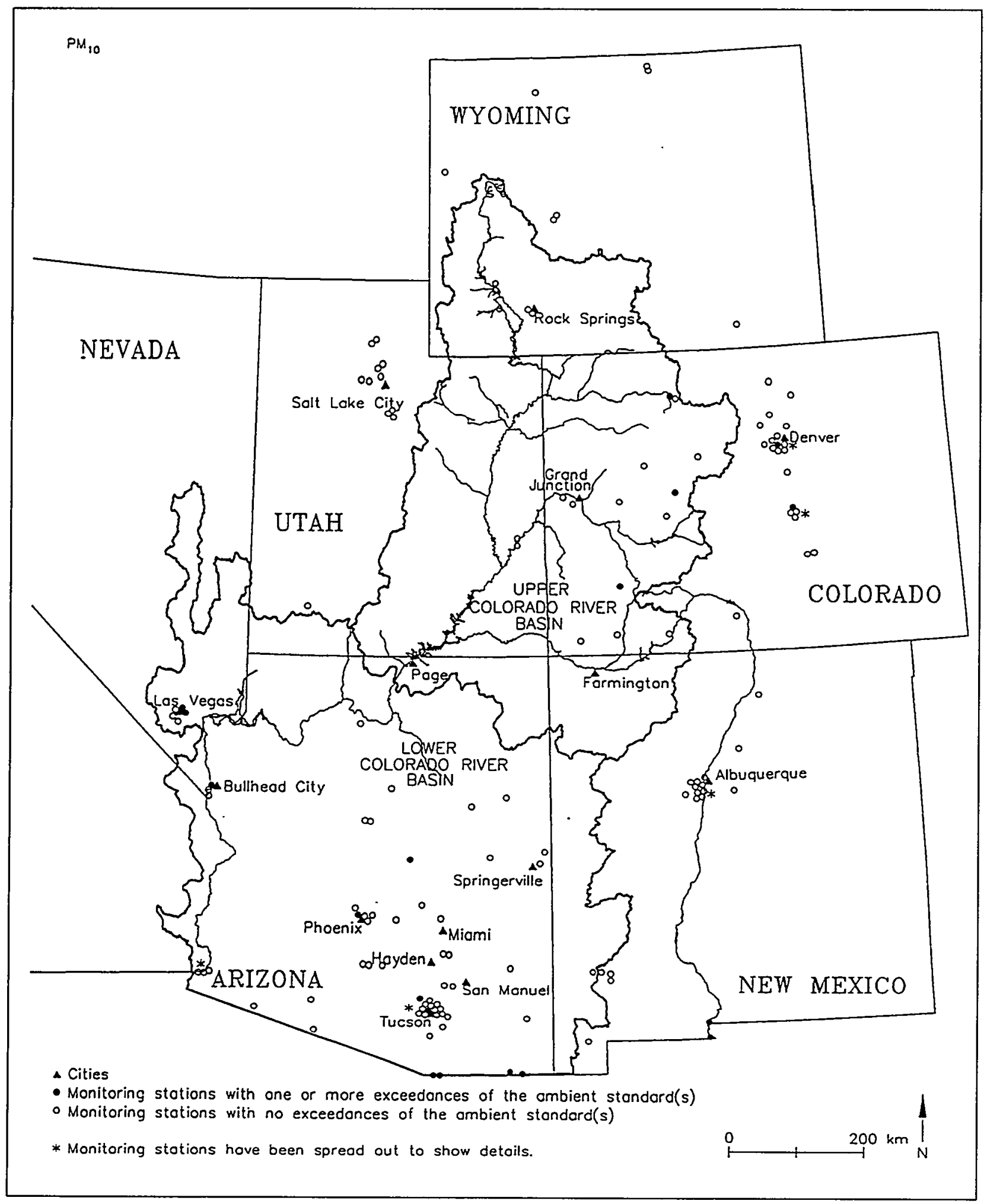

FIGURE A.5 Ambient Air Quality Monitoring Stations for $\mathrm{PM}_{10}$ Operating in 1989 within the Six-State Study Region 


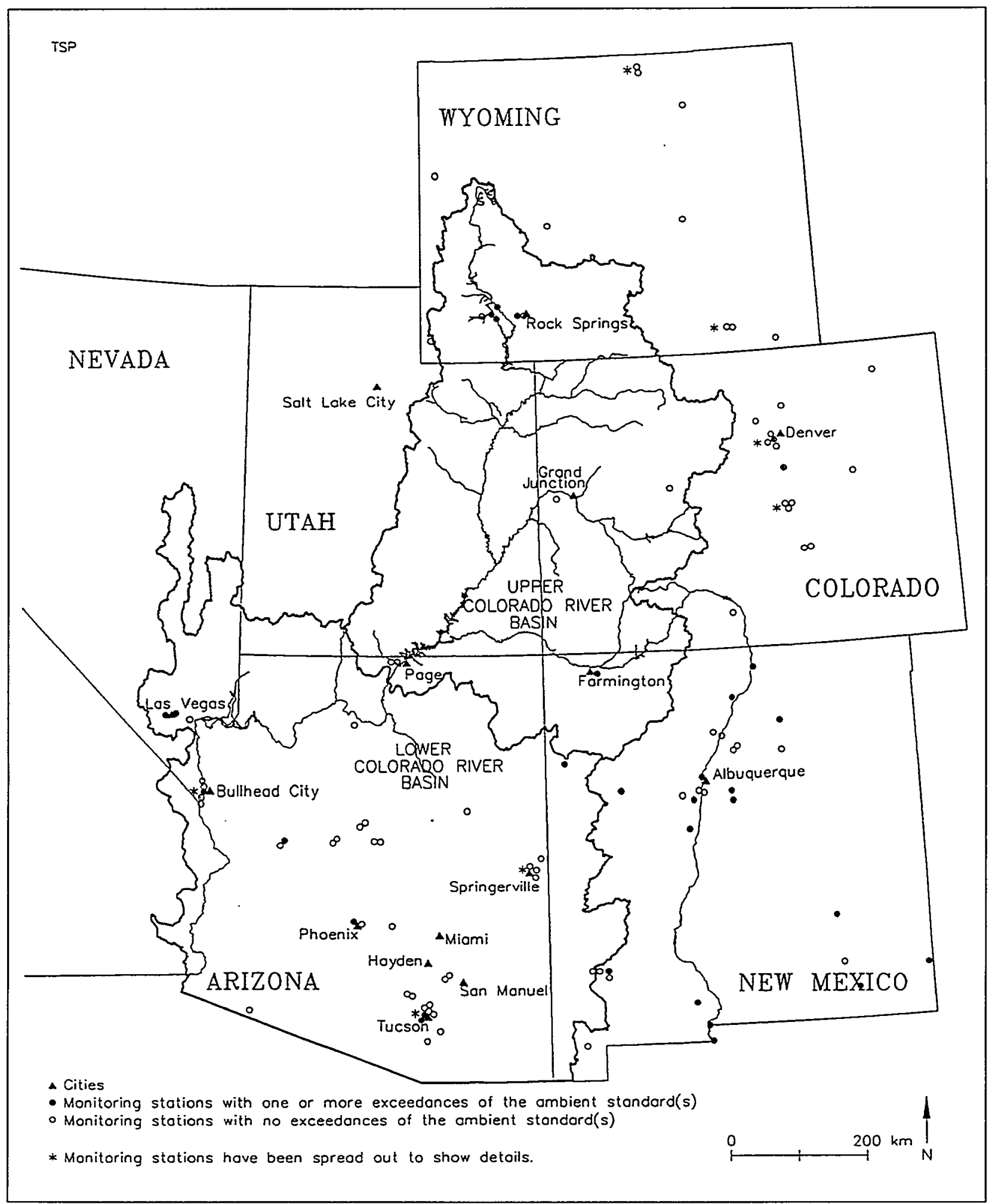

FIGURE A.6 Ambient Air Quality Monitoring Stations for TSP Operating in 1989 within the Six-State Study Region 


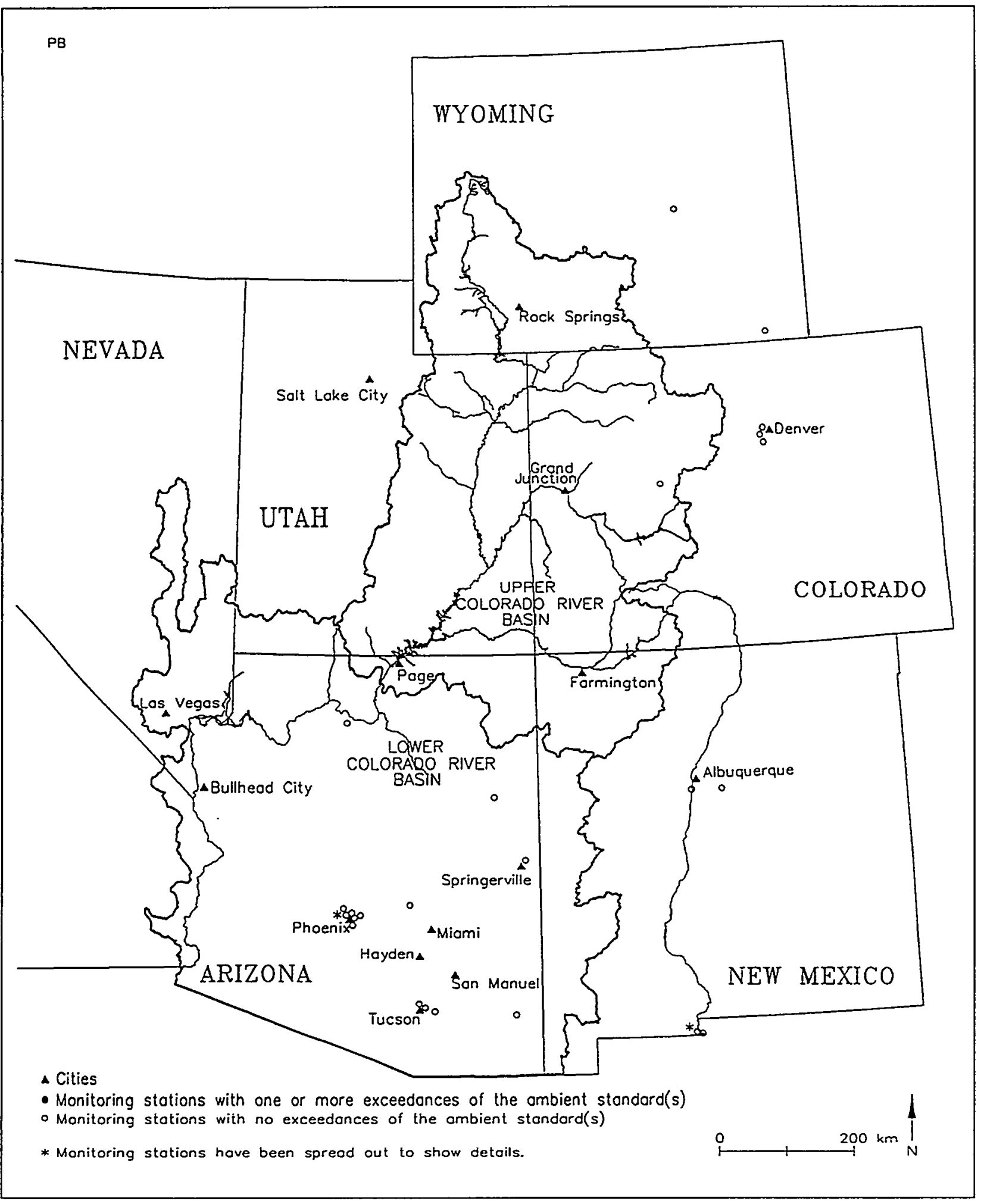

FIGURE A.7 Ambient Air Quality Monitoring Stations for Pb Operating in 1989 within the Six-State Study Region 
TABLE A.1 Estimated Air Quality Impacts of Electric Power Generation from Diesel Engine Operations ${ }^{\mathrm{a}}$

\begin{tabular}{|c|c|c|c|c|c|c|c|c|c|c|c|c|}
\hline \multirow[b]{2}{*}{$\begin{array}{c}\text { Nominal } \\
\text { Capacity } \\
\text { (MW) }\end{array}$} & \multirow[b]{2}{*}{ Pollutant } & \multirow[b]{2}{*}{$\begin{array}{l}\text { Averaging } \\
\text { Time }\end{array}$} & \multicolumn{2}{|c|}{$\begin{array}{l}\text { Maximum Source } \\
\text { Impact Level }\end{array}$} & \multicolumn{2}{|c|}{$\begin{array}{l}\text { Significant } \\
\text { Impact Level }\end{array}$} & \multicolumn{2}{|c|}{$\begin{array}{c}\text { Class I } \\
\text { PSD Increment }\end{array}$} & \multirow{2}{*}{$\begin{array}{c}\text { Class II } \\
\text { PSD } \\
\text { Conc. } \\
\text { Increment } \\
\left(\mu \mathrm{g} / \mathrm{m}^{3}\right)\end{array}$} & \multicolumn{2}{|c|}{$\begin{array}{l}\text { NAAQS } \\
\left(\mu g / \mathrm{m}^{3}\right)\end{array}$} & \multirow[b]{2}{*}{$\begin{array}{l}\text { SAAQS } \\
\left(\mu \mathrm{g} / \mathrm{m}^{3}\right)\end{array}$} \\
\hline & & & $\begin{array}{l}\text { Conc. } \\
\left(\mu g / m^{3}\right)\end{array}$ & $\begin{array}{l}\text { Distance } \\
\quad(\mathrm{mi})\end{array}$ & $\begin{array}{c}\text { Conc. } \\
\left(\mu \mathrm{g} / \mathrm{m}^{3}\right)\end{array}$ & $\begin{array}{l}\text { Distance } \\
(\mathrm{mi})\end{array}$ & $\begin{array}{c}\text { Conc. } \\
\left(\mu \mathrm{g} / \mathrm{m}^{3}\right)\end{array}$ & $\begin{array}{l}\text { Distance } \\
(\mathrm{mi})\end{array}$ & & Primary & $\begin{array}{l}\text { Secon- } \\
\text { dary }\end{array}$ & \\
\hline \multirow[t]{11}{*}{$2.4^{\mathrm{c}}$} & \multirow[t]{3}{*}{$\mathrm{SO}_{2}$} & Annual & $<0.05$ & 0.5 & 1 &.$d$ & 2 & . & 20 & 80 & $\mathrm{NS}^{\mathrm{e}}$ & 60 \\
\hline & & 24-hour & $<0.05$ & 0.6 & 5 & . & 5 & . & 91 & 365 & NS & 260 \\
\hline & & 3-hour & $<0.05$ & 0.6 & 25 & - & 25 & . & 512 & NS & 1,300 & 1,300 \\
\hline & \multirow{2}{*}{$\mathrm{NO}_{2}$} & Annual & 0.4 & 0.5 & 1 & - & 2.5 & . & 25 & 100 & 100 & 100 \\
\hline & & 24-hour & 2.8 & 0.6 & NS & $\mathrm{NA}^{\mathrm{f}}$ & NS & NA & NS & NS & NS & 200 \\
\hline & \multirow[t]{2}{*}{$\mathrm{Co}$} & 8-hour & 2.1 & 0.6 & 500 & . & NS & NA & NS & 10,000 & NS & 9,200 \\
\hline & & 1-hour & 3.9 & 0.4 & 2,000 & - & NS & NA & NS & 40,000 & NS & 14,800 \\
\hline & \multirow[t]{2}{*}{ TSP } & Annual & 0.1 & 0.5 & 1 & . & 5 & . & 19 & NS & NS & 60 \\
\hline & & 24hour & 0.4 & 0.6 & 5 & . & 10 & . & 37 & NS & NS & 150 \\
\hline & \multirow{2}{*}{$\mathrm{PM}_{10}$} & Annual & 0.1 & 0.5 & NS & NA & NS & NA & NS & 50 & 50 & 50 \\
\hline & & 24-hour & 0.4 & 0.6 & NS & $\mathrm{NA}$ & NS & NA & NS & 150 & 150 & 150 \\
\hline \multirow[t]{11}{*}{$4.0^{c}$} & \multirow{3}{*}{$\mathrm{SO}_{2}$} & Annual & $<0.05$ & 0.1 & 1 & . & 2 & . & 20 & 80 & NS & 60 \\
\hline & & 24-hour & $<0.05$ & 0.1 & 5 & - & 5 & . & 91 & 365 & NS & 260 \\
\hline & & 3-hour & 0.1 & 0.1 & 25 & . & 25 & - & 512 & NS & 1,300 & 1,300 \\
\hline & \multirow{2}{*}{$\mathrm{NO}_{2}$} & Annual & 0.9 & 0.1 & 1 & - & 2.5 & . & 25 & 100 & 100 & 100 \\
\hline & & 24-hour & 11.0 & 0.1 & NS & $\mathrm{NA}$ & NS & $\mathrm{NA}$ & NS & NS & NS & 200 \\
\hline & \multirow[t]{2}{*}{$\mathrm{CO}$} & 8-hour & 9.0 & 0.1 & 500 & - & NS & NA & NS & 10,000 & NS & 9,200 \\
\hline & & 1-hour & 12.0 & 0.1 & 2,000 & . & NS & $\mathrm{NA}$ & NS & 40,000 & NS & 14,800 \\
\hline & \multirow[t]{2}{*}{ TSP } & Annual & 0.1 & 0.1 & 1 & . & 5 & . & 19 & NS & NS & 60 \\
\hline & & 24hour & 1.6 & 0.1 & 5 & . & 10 & . & 37 & NS & NS & 150 \\
\hline & \multirow[t]{2}{*}{$P M_{10}$} & Annual & 0.1 & 0.1 & NS & NA & NS & $\mathrm{NA}$ & NS & 50 & 50 & 50 \\
\hline & & 24hour & 1.6 & 0.1 & NS & NA & NS & $\mathrm{NA}$ & NS & 150 & 150 & 150 \\
\hline
\end{tabular}




\section{TABLE A.1 (Cont.)}

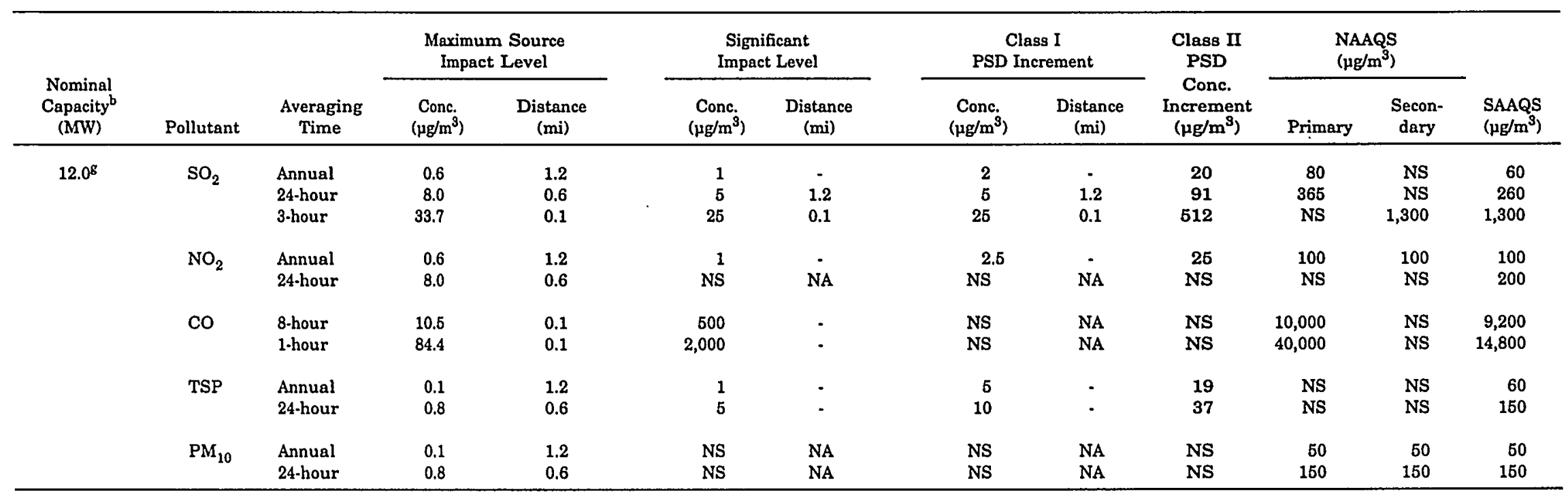

a Notation: Conc. $=$ concentration; NAAQS = National Ambient Air Quality Standards; PSD = Prevention of Significant Deterioration; SAAQS = State Ambient Air Quality Standards.

b Fuel designated for units with generating capacities of 2.4 and $4.0 \mathrm{MW}$ is natural gas, and that for the unit with generating capacity of $12 \mathrm{MW}$ is residual oil.

c Meteorological data (1984-1985 and 1987-1989) from Casper, Wyoming, were used in air quality modeling.

d A hyphen indicates that the estimated concentrations over the modeling domain with a radius of $50 \mathrm{~km}$ are below applicable concentration increment or level.

- NS indicates that no standard, increment, or impact level exists.

$f$ NA indicates not applicable.

B Meteorological data (1985-1989) from Salt Lake City, Utah, were used in air quality modeling. 
TABLE A.2 Estimated Air Quality Impacts of Electric Power Generation from Natural-Gas-Fired Gas Turbine Operations ${ }^{\mathrm{a}}$

\begin{tabular}{|c|c|c|c|c|c|c|c|c|c|c|c|c|}
\hline \multirow{2}{*}{$\begin{array}{c}\text { Nominal } \\
\text { Capacity } \\
\text { (MW) }\end{array}$} & \multirow[b]{2}{*}{ Pollutant } & \multirow[b]{2}{*}{$\begin{array}{l}\text { Averaging } \\
\text { Time }\end{array}$} & \multicolumn{2}{|c|}{$\begin{array}{l}\text { Maximum Source } \\
\text { Impact Level }\end{array}$} & \multicolumn{2}{|c|}{$\begin{array}{l}\text { Significant } \\
\text { Impact Level }\end{array}$} & \multicolumn{2}{|c|}{$\begin{array}{c}\text { Class I } \\
\text { PSD Increment }\end{array}$} & \multirow{2}{*}{$\begin{array}{l}\text { Class II } \\
\text { PSD } \\
\text { Conc. } \\
\text { Increment } \\
\left(\mu \mathrm{g} / \mathrm{m}^{3}\right)\end{array}$} & \multicolumn{2}{|c|}{$\begin{array}{l}\text { NAAQS } \\
\left(\mu \mathrm{g} / \mathrm{m}^{3}\right)\end{array}$} & \multirow[b]{2}{*}{$\begin{array}{l}\text { SAAQS } \\
\left(\mu \mathrm{g} / \mathrm{m}^{3}\right)\end{array}$} \\
\hline & & & $\begin{array}{c}\text { Conc. } \\
\left(\mu \mathrm{g} / \mathrm{m}^{3}\right)\end{array}$ & $\begin{array}{c}\text { Distance } \\
(\mathrm{mi})\end{array}$ & $\begin{array}{c}\text { Conc. } \\
\left(\mu \mathrm{g} / \mathrm{m}^{3}\right)\end{array}$ & $\begin{array}{c}\text { Distance } \\
\text { (mi) }\end{array}$ & $\begin{array}{c}\text { Conc. } \\
\left(\mathrm{\mu g} / \mathrm{m}^{3}\right)\end{array}$ & $\begin{array}{c}\text { Distance } \\
(\mathrm{mi})\end{array}$ & & Primary & $\begin{array}{l}\text { Secon. } \\
\text { dary }\end{array}$ & \\
\hline \multirow[t]{10}{*}{$8.8^{\mathrm{b}}$} & \multirow[t]{3}{*}{$\mathrm{SO}_{2}$} & Annual & $<0.05$ & 1.9 & 1 &.$c$ & 2 & . & 20 & 80 & $\mathrm{NS}^{\mathrm{d}}$ & 60 \\
\hline & & 24hour & $<0.05$ & 0.1 & 5 & . & 5 & . & 91 & 365 & NS & 260 \\
\hline & & 3-hour & 0.2 & 0.1 & 25 & - & 25 & . & 512 & NS & 1,300 & 1,300 \\
\hline & $\mathrm{NO}_{2}$ & 24-hour & 10.0 & 0.1 & NS & $N A^{e}$ & NS & NA & NS & NA & NS & 200 \\
\hline & \multirow[t]{2}{*}{$\mathrm{co}$} & 8-hour & 16.5 & 0.1 & 500 & . & NS & NA & NS & 10,000 & NS & 9,200 \\
\hline & & 1-hour & 85.7 & 0.1 & 2,000 & . & NS & $\mathrm{NA}$ & NS & 40,000 & NS & 14,800 \\
\hline & \multirow[t]{2}{*}{$\mathrm{TSP}$} & Annual & $<0.05$ & 1.9 & 1 & . & 5 & . & 19 & NS & NS & 60 \\
\hline & & 24-hour & 1.5 & 0.1 & 5 & - & 10 & - & 37 & NS & NS & 150 \\
\hline & \multirow[t]{2}{*}{$\mathrm{PM}_{10}$} & Annual & $<0.05$ & 1.9 & NS & $\mathrm{NA}$ & NS & NA & NS & 50 & 50 & 50 \\
\hline & & 24-hour & 1.5 & 0.1 & NS & $\mathrm{NA}$ & NS & NA & NS & 150 & 150 & 150 \\
\hline \multirow{10}{*}{$31.0^{r}$} & \multirow{2}{*}{$\mathrm{SO}_{2}$} & 24hour & $<0.05$ & 0.1 & 5 & . & 5 & . & 91 & 365 & NS & 260 \\
\hline & & 3-hour & 0.1 & 0.1 & 25 & - & 25 & . & 512 & NS & 1,300 & 1,300 \\
\hline & \multirow[t]{2}{*}{$\mathrm{NO}_{2}$} & Annual & 0.1 & 3.1 & 1 & - & 2.5 & . & 25 & 100 & 100 & 100 \\
\hline & & 24-hour & 9.5 & 0.1 & NS & $\mathrm{NA}$ & NS & NA & NS & 365 & NS & 260 \\
\hline & \multirow[t]{2}{*}{$\mathrm{CO}$} & 8-hour & 14.0 & 0.1 & 500 & . & NS & NA & NS & 10,000 & NS & 9,200 \\
\hline & & 1-hour & 18.5 & 0.1 & 2,000 & - & NS & NA & NS & 40,000 & NS & 14,800 \\
\hline & \multirow[t]{2}{*}{ TSP } & Annual & $<0.05$ & 3.1 & 1 & - & 5 & . & 19 & NS & NS & 60 \\
\hline & & 24-hour & 1.4 & 0.1 & 5 & - & 10 & - & 37 & NS & NS & 150 \\
\hline & \multirow[t]{2}{*}{$\mathrm{PM}_{10}$} & Annual & $<0.05$ & 3.1 & NS & $\mathrm{NA}$ & NS & $\mathrm{NA}$ & NS & 50 & 50 & 50 \\
\hline & & 24-hour & 1.4 & 0.1 & NS & NA & NS & NA & NS & 150 & 150 & 150 \\
\hline
\end{tabular}




\section{TABLE A.2 (Cont.)}

\begin{tabular}{|c|c|c|c|c|c|c|c|c|c|c|c|c|}
\hline \multirow{2}{*}{$\begin{array}{c}\text { Nominal } \\
\text { Capacity } \\
\text { (MW) }\end{array}$} & \multirow[b]{2}{*}{ Pollutant } & \multirow[b]{2}{*}{$\begin{array}{l}\text { Averaging } \\
\text { Time }\end{array}$} & \multicolumn{2}{|c|}{$\begin{array}{l}\text { Maximum Source } \\
\text { Impact Level }\end{array}$} & \multicolumn{2}{|c|}{$\begin{array}{l}\text { Significant } \\
\text { Impact Level }\end{array}$} & \multicolumn{2}{|c|}{$\begin{array}{c}\text { Class I } \\
\text { PSD Increment }\end{array}$} & \multirow{2}{*}{$\begin{array}{c}\text { Class II } \\
\text { PSD } \\
\text { Conc. } \\
\text { Increment } \\
\left(\mu \mathrm{g} / \mathrm{m}^{3}\right)\end{array}$} & \multicolumn{2}{|c|}{$\begin{array}{l}\text { NAAQS } \\
\left(\mu \mathrm{g} / \mathrm{m}^{3}\right)\end{array}$} & \multirow[b]{2}{*}{$\begin{array}{l}\text { SAAQS } \\
\left(\mu \mathrm{g} / \mathrm{m}^{3}\right)\end{array}$} \\
\hline & & & $\begin{array}{l}\text { Conc. } \\
\left(\mu \mathrm{g} / \mathrm{m}^{3}\right)\end{array}$ & $\begin{array}{l}\text { Distance } \\
\text { (mi) }\end{array}$ & $\begin{array}{l}\text { Conc. } \\
\left(\mu \mathrm{g} / \mathrm{m}^{3}\right)\end{array}$ & $\begin{array}{l}\text { Distance } \\
(\mathrm{mi})\end{array}$ & $\begin{array}{l}\text { Conc. } \\
\left(\mu \mathrm{g} / \mathrm{m}^{3}\right)\end{array}$ & $\begin{array}{l}\text { Distance } \\
\text { (mi) }\end{array}$ & & Primary & $\begin{array}{l}\text { Secon- } \\
\text { dary }\end{array}$ & \\
\hline \multirow[t]{10}{*}{$80.0^{\mathrm{g}}$} & $\mathrm{SO}_{2}$ & Annual & $<0.05$ & 6.2 & 1 & - & 2 & - & 20 & 80 & NS & 60 \\
\hline & & 24-hour & $<0.05$ & 6.2 & 5 & - & 5 & - & 91 & 365 & NS & 260 \\
\hline & & 3-hour & $<0.05$ & 3.1 & 25 & - & 25 & - & 512 & NS & 1,300 & 1,300 \\
\hline & & 24-hour & 0.8 & 6.2 & NS & NA & NS & NA & NS & NS & NS & 200 \\
\hline & $\mathrm{CO}$ & 8-hour & 0.9 & 6.2 & 600 & - & NS & NA & NS & 10,000 & NS & 9,200 \\
\hline & & 1-hour & 3.8 & 0.9 & 2,000 & - & NS & NA & NS & 40,000 & NS & 14,800 \\
\hline & TSP & Annual & $<0.05$ & 6.2 & 1 & . & 5 & - & 19 & NS & NS & 60 \\
\hline & & 24-hour & 0.1 & 6.2 & 5 & - & 10 & - & 37 & NS & NS & 150 \\
\hline & $\mathrm{PM}_{10}$ & Annual & $<0.05$ & 6.2 & NS & NA & NS & NA & NS & 50 & 50 & 50 \\
\hline & & 24-hour & 0.1 & 6.2 & NS & NA & NS & NA & NS & 160 & 150 & 150 \\
\hline
\end{tabular}

a Notation: Conc. $=$ concentration; NAAQS $=$ National Ambient Air Quality Standards; PSD = Prevention of Significant Deterioration; SAAQS = State Ambient Air Quality Standards.

b Meteorological data (1985-1989) from Salt Lake City, Utah, were used in air quality modeling.

c A hyphen indicates that the estimated concentrations over the modeling domain with a radius of $50 \mathrm{~km}$ are below applicable concentration increment or level.

d NS indicates that no standard, increment, or impact level exists.

e NA indicates not applicable.

f Meteorological data (1985-1989) from Albuquerque, New Mexico, were used in air quality modeling.

g Meteorological data (1985-1989) from Phoenix, Arizona, were used in air quality modeling. 
TABLE A.3 Estimated Air Quality Impacts of Electric Power Generation from Natural-Gas-Fired

Combined-Cycle Plant Operations ${ }^{\mathrm{a}}$

\begin{tabular}{|c|c|c|c|c|c|c|c|c|c|c|c|c|}
\hline \multirow{2}{*}{$\begin{array}{l}\text { Nominal } \\
\text { Capacity } \\
\text { (MW) }\end{array}$} & \multirow[b]{2}{*}{ Pollutant } & \multirow[b]{2}{*}{$\begin{array}{l}\text { Averaging } \\
\text { Time }\end{array}$} & \multicolumn{2}{|c|}{$\begin{array}{l}\text { Maximum Source } \\
\text { Impact Level }\end{array}$} & \multicolumn{2}{|c|}{$\begin{array}{l}\text { Significant } \\
\text { Impact Level }\end{array}$} & \multicolumn{2}{|c|}{$\begin{array}{c}\text { Class I } \\
\text { PSD Increment }\end{array}$} & \multirow{2}{*}{$\begin{array}{c}\text { Class II } \\
\text { PSD } \\
\text { Conc. } \\
\text { Increment } \\
\left(\mu \mathrm{g} / \mathrm{m}^{3}\right)\end{array}$} & \multicolumn{2}{|c|}{$\begin{array}{l}\text { NAAQS } \\
\left(\mu \mathrm{g} / \mathrm{m}^{3}\right)\end{array}$} & \multirow[b]{2}{*}{$\begin{array}{l}\text { SAAQS } \\
\left(\mu \mathrm{g} / \mathrm{m}^{3}\right)\end{array}$} \\
\hline & & & $\begin{array}{l}\text { Conc. } \\
\left(\mu g / \mathrm{m}^{3}\right)\end{array}$ & $\begin{array}{c}\text { Distance } \\
(\mathrm{mi})\end{array}$ & $\begin{array}{c}\text { Conc. } \\
\left(\mu \mathrm{g} / \mathrm{m}^{3}\right)\end{array}$ & $\begin{array}{c}\text { Distance } \\
(\mathrm{mi})\end{array}$ & $\underset{\left(\mu g / m^{3}\right)}{\text { Conc. }}$ & $\begin{array}{l}\text { Distance } \\
(\mathbf{m i})\end{array}$ & & Primary & $\begin{array}{l}\text { Secon. } \\
\text { dary }\end{array}$ & \\
\hline \multirow[t]{11}{*}{$15.9^{\mathrm{b}}$} & \multirow{3}{*}{$\mathrm{SO}_{2}$} & Annual & $<0.05$ & 0.1 & 1 &.$c$ & 2 & . & 20 & 80 & $N S^{d}$ & 60 \\
\hline & & 24-hour & 0.1 & 0.1 & 5 & . & $\mathbf{5}$ & . & 91 & 365 & NS & 260 \\
\hline & & 3-hour & 0.3 & 0.1 & 25 & - & 25 & - & 512 & NS & 1,300 & 1,300 \\
\hline & \multirow[t]{2}{*}{$\mathrm{NO}_{2}$} & Annual & 0.6 & 0.1 & 1 & $\cdot$ & 2.5 & . & 25 & 100 & 100 & 100 \\
\hline & & 24-hour & 25.4 & 0.1 & NS & $\mathrm{NA}^{\mathrm{e}}$ & NS & NA & NS & NS & NS & 200 \\
\hline & \multirow{2}{*}{$\mathrm{CO}$} & 8-hour & 30.5 & 0.1 & 500 & . & NS & NA & NS & 10,000 & NS & 9,200 \\
\hline & & 1.hour & 75.8 & 0.1 & 2,000 & - & NS & NA & NS & 40,000 & NS & 14,800 \\
\hline & \multirow[t]{2}{*}{ TSP } & Annual & 0.1 & 0.1 & 1 & - & 5 & - & 19 & NS & NS & 60 \\
\hline & & 24-hour & 3.8 & 0.1 & 5 & - & 10 & $\cdot$ & 37 & NS & NS & 150 \\
\hline & \multirow{2}{*}{$\mathrm{PM}_{10}$} & Annual & 0.1 & 0.1 & NS & NA & NS & $N A$ & NS & 50 & 50 & 50 \\
\hline & & 24-hour & 3.8 & 0.1 & NS & NA & NS & NA & NS & 150 & 150 & 150 \\
\hline \multirow[t]{11}{*}{$50.0^{f}$} & \multirow[t]{3}{*}{$\mathrm{SO}_{2}$} & Annual & $<0.05$ & 1.2 & 1 & . & 2 & - & 20 & 80 & NS & 60 \\
\hline & & 24-hour & $<0.05$ & 0.1 & 5 & - & 5 & - & 91 & 365 & NS & 260 \\
\hline & & 3-hour & 0.2 & 0.1 & 25 & - & 25 & $\cdot$ & 512 & NS & 1,300 & 1,300 \\
\hline & \multirow[t]{2}{*}{$\mathrm{NO}_{2}$} & Annual & 0.7 & 1.2 & 1 & - & 2.5 & - & 25 & 100 & 100 & 100 \\
\hline & & 24-hour & 13.2 & 0.1 & NS & NA & NS & NA & NS & NS & NS & 200 \\
\hline & \multirow[t]{2}{*}{$\mathrm{CO}$} & 8-hour & 15.6 & 0.1 & 500 & - & NS & $\mathrm{NA}$ & NS & 10,000 & NS & 9,200 \\
\hline & & 1-hour & 124.8 & 0.1 & 2,000 & . & NS & $\mathrm{NA}$ & NS & 40,000 & NS & 14,800 \\
\hline & \multirow{2}{*}{ TSP } & Annual & 0.1 & 1.2 & 1 & . & 5 & . & 19 & NS & NS & 60 \\
\hline & & 24-hour & 2.0 & 0.1 & 5 & - & 10 & - & 37 & NS & NS & 150 \\
\hline & \multirow[t]{2}{*}{$\mathrm{PM}_{10}$} & Annual & 0.1 & 1.2 & NS & $\mathrm{NA}$ & NS & NA & NS & 50 & 50 & 50 \\
\hline & & 24-hour & 2.0 & 0.1 & NS & NA & NS & $\mathrm{NA}$ & NS & 150 & 150 & 150 \\
\hline
\end{tabular}




\section{TABLE A.3 (Cont.)}

\begin{tabular}{|c|c|c|c|c|c|c|c|c|c|c|c|c|}
\hline \multirow{2}{*}{$\begin{array}{c}\text { Nominal } \\
\text { Capacity } \\
\text { (MW) }\end{array}$} & \multirow[b]{2}{*}{ Pollutant } & \multirow[b]{2}{*}{$\begin{array}{l}\text { Averaging } \\
\text { Time }\end{array}$} & \multicolumn{2}{|c|}{$\begin{array}{l}\text { Maximum Source } \\
\text { Impact Level }\end{array}$} & \multicolumn{2}{|c|}{$\begin{array}{l}\text { Significant } \\
\text { Impact Level }\end{array}$} & \multicolumn{2}{|c|}{$\begin{array}{c}\text { Class I } \\
\text { PSD Increment }\end{array}$} & \multirow{2}{*}{$\begin{array}{l}\text { Class II } \\
\text { PSD } \\
\text { Conc. } \\
\text { Increment } \\
\left(\mu \mathrm{g} / \mathrm{m}^{3}\right)\end{array}$} & \multicolumn{2}{|c|}{$\begin{array}{l}\text { NAAQS } \\
\left(\mu g / m^{3}\right)\end{array}$} & \multirow[b]{2}{*}{$\begin{array}{l}\text { SAAQS } \\
\left(\mu g / \mathrm{m}^{3}\right)\end{array}$} \\
\hline & & & $\begin{array}{l}\text { Conc. } \\
\left(\mu g / m^{3}\right)\end{array}$ & $\begin{array}{l}\text { Distance } \\
\text { (mi) }\end{array}$ & $\begin{array}{c}\text { Conc. } \\
\left(\mu g / m^{3}\right)\end{array}$ & $\begin{array}{l}\text { Distance } \\
\text { (mi) }\end{array}$ & $\begin{array}{l}\text { Conc. } \\
\left(\mu g / m^{3}\right)\end{array}$ & $\begin{array}{l}\text { Distance } \\
\text { (mi) }\end{array}$ & & Primary & $\begin{array}{l}\text { Secon- } \\
\text { dary }\end{array}$ & \\
\hline \multirow[t]{11}{*}{$100.0^{f}$} & \multirow[t]{3}{*}{$\mathrm{SO}_{2}$} & Annual & $<0.05$ & 1.9 & 1 & . & 2 & - & 20 & 80 & NS & 60 \\
\hline & & 24-hour & $<0.05$ & 0.1 & 5 & . & 5 & - & 91 & 365 & NS & 260 \\
\hline & & 3-hour & 0.2 & 0.1 & 25 & $\cdot$ & 25 & - & 512 & NS & 1,300 & 1,300 \\
\hline & \multirow[t]{2}{*}{$\mathrm{NO}_{2}$} & Annual & 0.9 & 1.9 & 1 & - & 2.5 & - & 25 & 100 & 100 & 100 \\
\hline & & 24-hour & 9.9 & 0.1 & NS & $\mathrm{NA}$ & NS & NA & NS & NS & NS & 200 \\
\hline & \multirow[t]{2}{*}{$\mathrm{CO}$} & 8-hour & 16.3 & 0.1 & 500 & - & NS & NA & NS & 10,000 & NS & 9,200 \\
\hline & & 1-hour & 130.5 & 0.1 & 2,000 & - & NS & NA & NS & 40,000 & NS & 14,800 \\
\hline & \multirow[t]{2}{*}{ TSP } & Annual & 0.1 & 1.9 & 1 & . & 5 & . & 19 & NS & NS & 60 \\
\hline & & 24-hour & 1.5 & 0.1 & 5 & $\cdot$ & 10 & - & 37 & NS & NS & 150 \\
\hline & \multirow[t]{2}{*}{$\mathrm{PM}_{10}$} & Annual & 0.1 & 1.9 & NS & $\mathrm{NA}$ & NS & NA & NS & 50 & 50 & 50 \\
\hline & & 24-hour & 1.5 & 0.1 & NS & NA & NS & NA & NS & 150 & 150 & 150 \\
\hline
\end{tabular}

a Notation: Conc. $=$ concentration; NAAQS $=$ National Ambient Air Quality Standards; PSD = Prevention of Significant Deterioration; SAAQS = State Ambient Air Quality Standards.

b Meteorological data (1985-1989) from Albuquerque, New Mexico, were used in air quality modeling.

c A hyphen indicates that the estimated concentrations over the modeling domain with a radius of $50 \mathrm{~km}$ are below applicable concentration increment or level.

d NS indicates that no standard, increment, or impact level exists.

e NA indicates not applicable.

f Meteorological data (1985-1989) from Phoenix, Arizona, were used in air quality modeling. 
TABLE A.4 Estimated Air Quality Impacts of Electric Power Generation from Pulverized-Coal-Fired Plant Operations ${ }^{\mathrm{a}}$

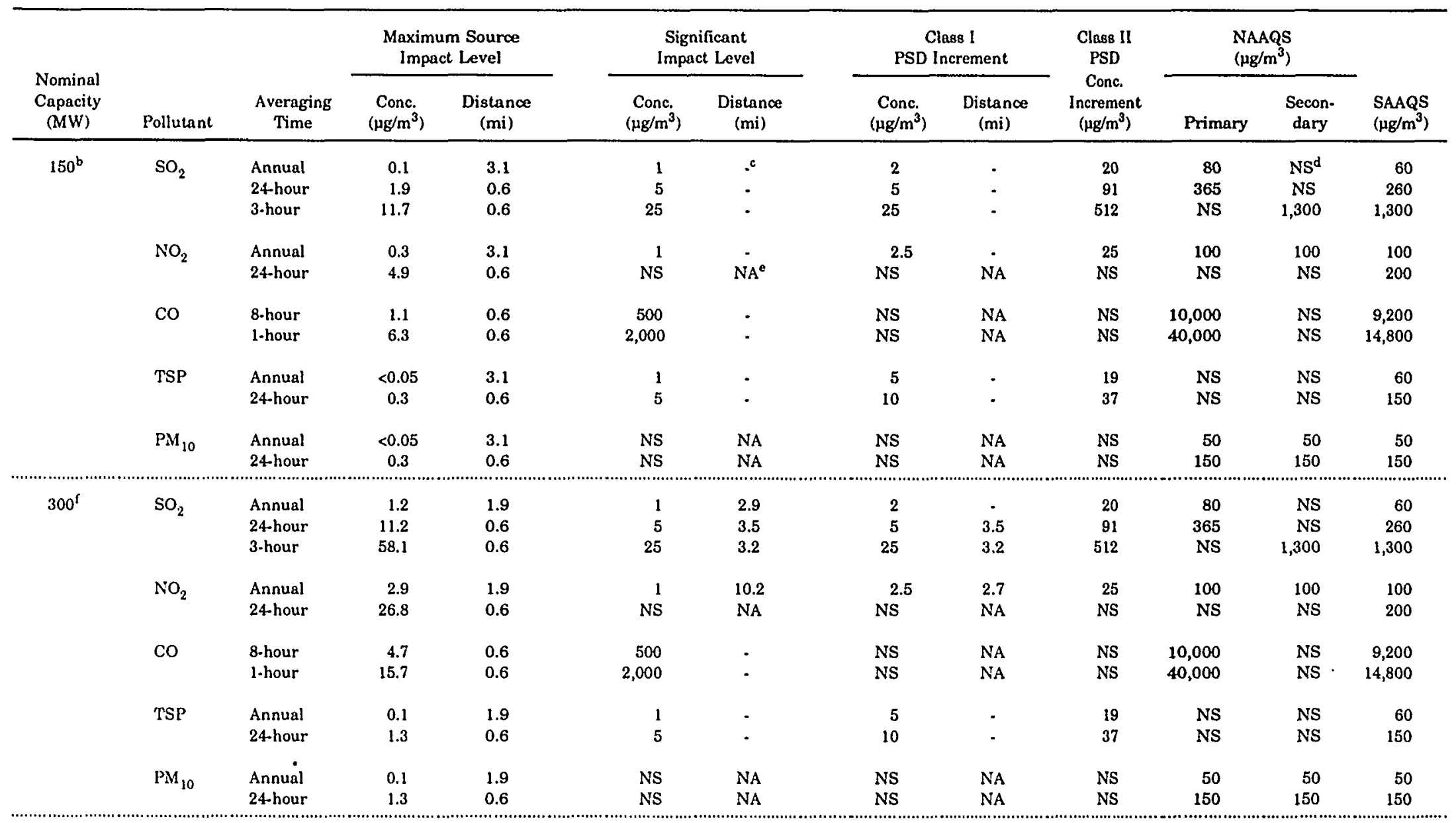


TABLE A.4 (Cont.)

\begin{tabular}{|c|c|c|c|c|c|c|c|c|c|c|c|c|}
\hline \multirow{2}{*}{$\begin{array}{c}\text { Nominal } \\
\text { Capacity } \\
\text { (MW) }\end{array}$} & \multirow[b]{2}{*}{ Pollutant } & \multirow[b]{2}{*}{$\begin{array}{l}\text { Averaging } \\
\text { Time }\end{array}$} & \multicolumn{2}{|c|}{$\begin{array}{l}\text { Maximum Source } \\
\text { Impact Level }\end{array}$} & \multicolumn{2}{|c|}{$\begin{array}{c}\text { Significant } \\
\text { Impact Level }\end{array}$} & \multicolumn{2}{|c|}{$\begin{array}{c}\text { Class I } \\
\text { PSD Increment }\end{array}$} & \multirow{2}{*}{$\begin{array}{l}\text { Class II } \\
\text { PSD } \\
\text { Conc. } \\
\text { Increment } \\
\left(\mu \mathrm{g} / \mathrm{m}^{3}\right)\end{array}$} & \multicolumn{2}{|c|}{$\begin{array}{l}\text { NAAQS } \\
\left(\mu \mathrm{g} / \mathrm{m}^{3}\right)\end{array}$} & \multirow[b]{2}{*}{$\begin{array}{l}\text { SAAQS } \\
\left(\mu \mathrm{g} / \mathrm{m}^{3}\right)\end{array}$} \\
\hline & & & $\begin{array}{l}\text { Conc. } \\
\left(\mathrm{pg} / \mathrm{m}^{3}\right)\end{array}$ & $\begin{array}{l}\text { Distance } \\
(\mathrm{mi})\end{array}$ & $\begin{array}{l}\text { Conc. } \\
\left(\mu g / m^{3}\right)\end{array}$ & $\begin{array}{l}\text { Distance } \\
(\mathrm{mi})\end{array}$ & $\begin{array}{l}\text { Conc. } \\
\left(\mu \mathrm{g} / \mathrm{m}^{3}\right)\end{array}$ & $\begin{array}{l}\text { Distance } \\
\text { (mi) }\end{array}$ & & Primary & $\begin{array}{l}\text { Secon- } \\
\text { dary }\end{array}$ & \\
\hline \multirow[t]{11}{*}{$350^{\mathrm{b}}$} & $\mathrm{SO}_{2}$ & Annual & 0.3 & 0.5 & 1 & - & 2 & . & 20 & 80 & NS & 60 \\
\hline & & 24-hour & 4.2 & 0.4 & 5 & . & 5 & . & 91 & 365 & NS & 260 \\
\hline & & 3-hour & 20.2 & 0.9 & 25 & - & 25 & - & 512 & NS & 1,300 & 1,300 \\
\hline & $\mathrm{NO}_{2}$ & Annual & 0.6 & 0.5 & 1 & - & 2.5 & - & 25 & 100 & 100 & 100 \\
\hline & & 24-hour & 10.6 & 0.4 & NS & NA & NS & NA & NS & NS & NS & 200 \\
\hline & $\mathrm{co}$ & 8-hour & 2.2 & 0.4 & 600 & - & NS & NA & NS & 10,000 & NS & 9,200 \\
\hline & & 1-hour & 8.3 & 0.9 & 2,000 & - & NS & $\mathrm{NA}$ & NS & 40,000 & NS & 14,800 \\
\hline & TSP & Annual & $<0.05$ & 0.5 & 1 & - & 5 & - & 19 & NS & NS & 60 \\
\hline & & 24-hour & 0.6 & 0.4 & 5 & - & 10 & - & 37 & NS & NS & 150 \\
\hline & $\mathrm{PM}_{10}$ & Annual & $<0.05$ & 0.5 & NS & NA & NS & NA & NS & 50 & 50 & 50 \\
\hline & & 24-hour & 0.6 & 0.4 & NS & NA & NS & NA & NS & 160 & 150 & 150 \\
\hline
\end{tabular}

a Notation: Conc. $=$ concentration; NAAQS $=$ National Ambient Air Quality Standards; PSD = Prevention of Significant Deterioration; SAAQS $=$ State Ambient Air Quality

Meteorological data (1985-1989) from Denver, Colorado, were used in air quality modeling.

c A hyphen indicates that the estimated concentrations over the modeling domain with a radius of $50 \mathrm{~km}$ are below applicable concentration increment or level.

d NS indicates that no standard, increment, or impact level exists.

e NA indicates not applicable.

f Meteorological data (1985-1989) from Phoenix, Arizona, were used in air quality modeling. 